\title{
ABSORÇÃO DE MACRONUTRIENTES E ACUMULAÇÃO DE MATÉRIA SECA PARA DUAS CULTIVARES DE MANDIOCA (Manihot esculenta, Crantz)
}

JOSÉ OSMAR LORENZI

Orientador: E. Malavolta

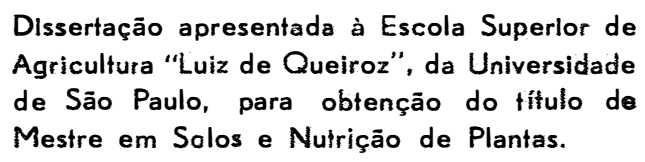

$P \mid R A C I C A B A$

Esłado de São Paulo - Brasil

Dezembro, 1978 
A minha esposa, Maria Helena
A meus filhos,
Alexandre
Rogêrio

DEDICO 
Manifestamos nossos agradecimentos a todos que, dire ta ou indiretamente, colaboraram para a realização deste traba Iho e, particularmente, as seguintes pessoas e Instituições:

- Ao Prof. Dr. Euripedes Malavolta, pela orientação segura du rante a execução deste trabalio:

- Ao Dr. José Romano Gallo, pelo apolo concedido na execução das análises químicas;

- Ao Prof. Dr. Humberto de Campos, pela orientação na condução das análises estatisticas;

- Aos colegas Araken Soares Pereira, Hilário da Silva Mi randa Filiho, Domingos Antonio Monteiro, Jairo Lopes de Castro e demais funcionários da Seção de Rafzes a Tubérculos, pelo alto espirito de compreensão e colaboração,sem o qual não seria possível a realização do presente trabalho;

- Ao pesquisador Manuel Cláudio Motta Macedo, pelas sugestöes apresentadas;

- Á Bibliotecária Sonia Corrêa da Rocha, pelo auxilio nas correções das citações bibliográficas;

- A Escola Superior de Agricultura "Luiz de Quelroz", a a Instituto Agronómico do Estado de São Paulo, pela oportínidade que nos foi concedida para frequentar o Curso de Pós-graduação: 
111.

- Ao Conselho Nacional de Desenvolvimento Cientifico e Tecno lógico (CNPq), pelo auxílio financelro possibilitando a execução deste trabaliho. 
2 - INTRODUÇÃo $\ldots \ldots \ldots \ldots \ldots \ldots \ldots \ldots \ldots \ldots \ldots \ldots \ldots \ldots \ldots \ldots \ldots$

3 - REVISÃo DE LITERATURA ................. 8

4 - MATERIAL E METOdOS ................... 25

5 - RESULtADOS E dISCUSSÃo ................... 33

5.1 - Crescimento ................... 33

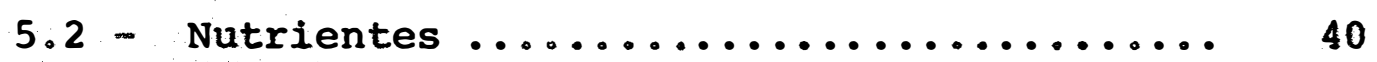

5.2 .1 - Nitrogênio ............... 40

5.2 .2 - Fósforo ................. 46

5.2 .3 - Potássio ................. 52

5.2 .4 - cálcio ................... 58

5.2 .5 - Magnésio .................. 65

5.2 .6 - Enxofre ................. 71

5.3 - Produção de Raizes ............... 77

5.4 - Extração e Exportação de Nutrientes .... 79

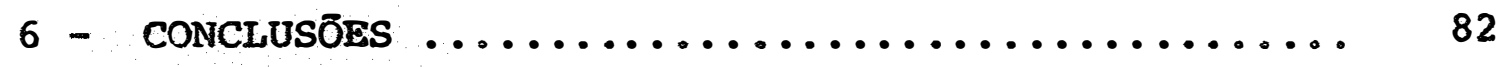

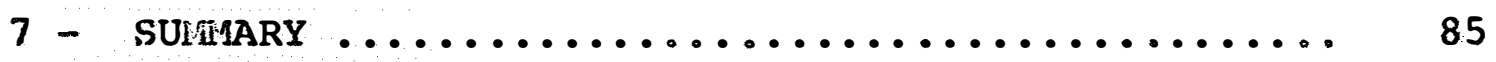

8 - IITERATURA CITADA ....................... 87 
1 - RESUMO

0 presente trabalho teve por objetivo verificar a produção de matéria seca, absorção dos macronutrientes em diversas fases do desenvolvimento, extração e exportação dos macronutrientes e produção de raízes para as cultivares de mandioca Branca de Santa Catarina e IAC Mantiqueira.

0 experimento foi instalado em ärea do Centro Experi mental de Campinas, I.A.C., SP, no ano agrícola $1975 / 76$, em solo de grande grupo Latossolo Roxo.

Utilizou-se uma adubação $N-\mathrm{P}_{2}{ }^{0}{ }_{5}-\mathrm{K}_{2}{ }^{0}$ de $40-$ $80-60 \mathrm{~kg} / \mathrm{ha}$. O nitrogênio, na forma de sulfato de amôneo, foi aplicado somente em cobertura aos 60 dias após a brotação. 
o fósforo e o potássio, na forma de superfosfato simples e clo reto de potássio, respectivamente, foram aplicados no fundo dos sulcos por ocasião do plantio.

0 experimento foi irrigado duas veres, aos 15 e 45 dias após o plantio, com a finalidade de se obter bom "stand" e uniformidade das plantas, em virtude da estiagem que ocorreu neste periodo.

As plantas foram amostradas em 6 (seis) épocas do de senvolvimento a intervalos regulares de 60 dias. As plantas a mostradas foram divididas em raízes, hastes e folhas e analisa das para N,P, K, Ca, Mg e S .

0 delineamento adotado foi o de blocos ao acaso. As curvas representativas da acumulação da matéria seca e nutrien tes, pela planta inteira e pelas raizes, foram obtidas a partir dos dados calculados por equações de regressão. As quantí dades extraídas de nutrientes foram calculadas através do ponto de máximo destas equações.

As principais conclusões e os dados mais relevantes foram os seguintes:

- Houve diferença estatística na produção de raízes das cultivares;

- O perỉodo de maior acumulação de matéria seca foi dos 120 aos 180 dias após a emergência;

- A exigência máxima de macronutrientes coincidiu com o período de máxima acumulação de matéria seca; 
- A extração de macronutrientes foi a mesma para as duas cultivares, exceto para o P . A exportação foi diferente somente para $O \mathrm{~K}$ e $\mathrm{S}$. 


\section{2 - INTRODUÇAOO}

A mandioca (Manihot esculenta, Crantz) é considerada pela maioria dos estudiosos do assunto como planta originária do Brasil.

Atualmente, a cultura da mandioca, no mundo, estendese numa ampla faixa compreendida entre 30 de latitude norte a sul e è conhecida como planta rústica no tocante a pragas e mo léstias, a fertilidade do solo e a oscilações climáticas.

De acordo com a concentração de ácido cianídrico nas raizes (PEREIRA et alii, 1977), substância oriunda da hidrólise de um cianoglucosídio comum a todas as variedades de mandio ca, estas podem ser classificadas em três grupos, a saber: 
mansas, até $100 \mathrm{ppm}$; intermediärias, de 100 a 200 ppm e bravas ou tóxicas, com mais de 200 ppm.

A mandioca pode ser considerada como planta de aproveitamento integral, uma vez que suas raízes e folhas são exce lentes fontes de carbohidratos e proteínas, respectivamente. As raízes são largamente utilizadas na alimentação direta do homem e dos animais (variedades mansas), ou como matéria prima industrial de um grande número de produtos dos quais destacamse o amido, farinha de mesa, raspa e farinha de raspa e ālcool (variedades mansas ou bravas). As folhas, de uso bem menor, a presentam proteína suficiente para merecer maior atenção com vistas a seu aproveitamento. NORMANHA (1966) relata teores en contrados de 16 a $22 \%$ e de 19 a $40 \%$ de proteína na matéria seca das folhas, em variedades do Estado de São Paulo e Pará,res pectivamente. Ressalta ainda, que as folhas possuem razoáveis teores de cálcio, fósforo, ferro e vitaminas, apresentando,por 100 gramas de folhas frescas, a seguinte variação:

\begin{tabular}{|c|c|c|c|}
\hline Proteínas ...... & 4 & $\mathbf{a}$ & $7,5 \mathrm{~g}$ \\
\hline cálcio .......... & 100 & $\mathbf{a}$ & 210 \\
\hline Ferro $\ldots \ldots \ldots$ & 2 & $\mathbf{a}$ & $3,5 \mathrm{mg}$ \\
\hline Vitamina $A \ldots$ & 9.000 & $\mathbf{a}$ & $13.000 \mathrm{U} . \mathrm{I}$. \\
\hline Vitamina $B_{1} \ldots$ & 0,15 & $\mathbf{a}$ & $0,30 \mathrm{mg}$ \\
\hline Riboflavina $\ldots$. & 0,25 & $\mathbf{a}$ & $0,43 \mathrm{mg}$ \\
\hline Niacina & 0,85 & $\mathbf{a}$ & $3,53 \mathrm{mg}$ \\
\hline Vitamina $c \ldots$. & 100 & $\mathbf{a}$ & $320 \mathrm{mg}$ \\
\hline
\end{tabular}


Com cerca de trinta milhões de toneladas anuais, o Brasil ocupa o primeiro lugar em produção, representando aproximadamente $30 \%$ da produção mundial (NESTEL, 1973). Ela é pro duzida em todos estados da federação e em volume de produção, depois da cana-de-açūcar, é a mais importante do país. (IBGE, 1975). Embora o rendimento nacional de $12,6 \mathrm{t} / \mathrm{ha}$ seja maior que a média mundial $(9,1 \mathrm{t} / \mathrm{ha}$, FAO, 1975) é forçoso reconhe cer que a mandioca é uma de nossas culturas de mais baixa apli cação tecnológica.

A literatura mostra que a mandioca retira do solo quantidades relativamente grandes de minerais, principalmente de potássio; no entanto, no Brasil, é prática corrente culti vä-1a nos solos mais pobres, mesmo sem adubação, onde ela pode competir favoravelmente com outras culturas.

A Seção de Raízes e Tubérculos - Instituto Agronômi co de Campinas, são Paulo - iniciou os estudos de adubação da mandioca em 1937 e até o presente realizou cerca de 150 ensaios nos diferentes tipos de solo do Estado de São Paulo. De uma maneira geral, o fósforo foi o elemento que mais incrementou a produção de raỉzes. 0 potâssio e o nitrogênio contribuíram pouco.

Cumpre salientar que a grande maioria desses ensaios foram conduzidos em āreas temporärias e com a cultivar Branca de Santa Catarina, a mais cultivada, ainda atualmente, no Estado de São Paulo (INStituto AgRonômico, 1937 / 1973). 
Os estudos sobre nutrição mineral da mandioca são muito escassos. Assim, torna-se necessärio verificar aspec tos de suas exigências minerais, principalmente em se tratando de una cultura que os exige em grande quantidade e que promete sair da primitividade agrícola em que se encontra para tornarmse uma cultura ampla e racional, com vistas a ateader à produção de álcool combustível motivado pela crise mundial de energia. Esta necessidade é reforçada pela pretensão de se utilizar amplas áreas disponíveis de cerrado, de pobreza mine ral acentuada, aproveitando-se de sua fácil adaptação e rusticidade.

0 presente trabalho teve por objetivo verificar as ne cessidades nutricionais e suas possiveis diferenças entre a cultivar IAC Mantiqueira (mandioca mansa) e a cultivar Branca de Santa Catarina (mandioca brava ou tóxica), nos seguintes aspectos:
a) produção de matéria seca;
b) absorção dos macronutrientes em diversas fases do de- senvolvimento;
c) extração e exportação dos macronutrientes;
d) produção de raízes. 


\section{1 - Concentração de Nutrientes}

A mandioca ocupa nas regiões tropicais um ponto tão importante quanto o milho e o arroz todavia, no campo da divul gação, há grande disparidade de volume entre os trabalhos a ela dedicados e os referentes às outras duas culturas, disparidade essa que implica numa diferença estimada da ordem de 5 a 6 para 1 (AlBUQUERQUe, 1969).

Trabalhos específicos sobre nutrição mineral da mandioca são escassos na literatura. Assim, a Tabela 1 resume os teores dos macronutrientes estudados, citados na literatura, em diferentes partes da planta, condições de cultivo e épocas de amostragem. 
Como se pode observar, existe pequena variação nos dados apresentados que é devida, principalmente, ao reduzido nūmero de trabalhos além de terem sido conduzidos em condições normais de cultivo, sem omissão de nutrientes. As variações e xistentes são devidas, entre outros fatores, a época de amostragem e cultivares utilizadas

0s intervalos de variação para cada elemento, resultantes da Tabela 1 , estão contidos na Tabela 2 ál.

Pelo exposto, verifica-se que os dados obtidos em campo prevalecem sobre os demais. Também observa-se que o en xofre é o elemento menos estudado e o nitrogênio é o que apresenta maior intervalo de variação.

Estudos sobre níveis deficientes e críticos de nutri entes nas diferentes partes da planta são ainda mais reduridos. KROCHMAL e SAMUELS (1968) cultivaram plantas de mandioca em areia lavada com solução nutritiva completa e omissão de nutrientes e analisaram as folhas, peciolos e hastes aos 90 dias de idade. Os resultados obtidos com a solução completa já foram citados na Tabela 1. As plantas que cresceram em tratamentos deficientes (ausēncia do elemento), apresentaram os seguintes teores:

al No presente trabalho os resultados säo sempre referentes a matérla seca, salvo indicação em conträrio. 


\begin{tabular}{lccr} 
Tratamento & Folha & Peciolo & Paste \\
\hline Sem N (\%) & 2,62 & 0,78 & 0,70 \\
Sem P (\%) & 0,20 & 0,10 & 0,10 \\
Sem K (\%) & 1,34 & 1,18 & 1,07 \\
Sem Ca (\%) & 1,83 & 1,75 & 0,37 \\
Sem Mg (\%) & 0,48 & 0,43 & 0,09 \\
\hline
\end{tabular}

MALAVOLTA et alii (1954) conduziram um ensaio em areia lavada com diferentes niveis de NPK, usando a variedade Branca de Santa Catarina. Os teores encontrados de nitrogê nio nas raizes, (transformados do original de \% proteína para \% nitrogênio) aos 10 meses de idade,para os tratamentos $\mathrm{N}_{0} \mathrm{P}_{1} \mathrm{~K}_{1}, \mathrm{~N}_{1} \mathrm{P}_{1} \mathrm{~K}_{1}$ e $\mathrm{N}_{2} \mathrm{P}_{1} \mathrm{~K}_{1}$ foram $0,25 \%, 0,47 \%$ e $0,82 \%$, respectivamente. Segundo os autores a dose dupla de nitrogênio garantiu a maior produção de raízes entretanto, acarretou uma queda na porcentagem de amido de $32 \%$ para $24 \%$ e como consequên cia a quantidade total de amido obtida não diferiu da dose sim ples. 


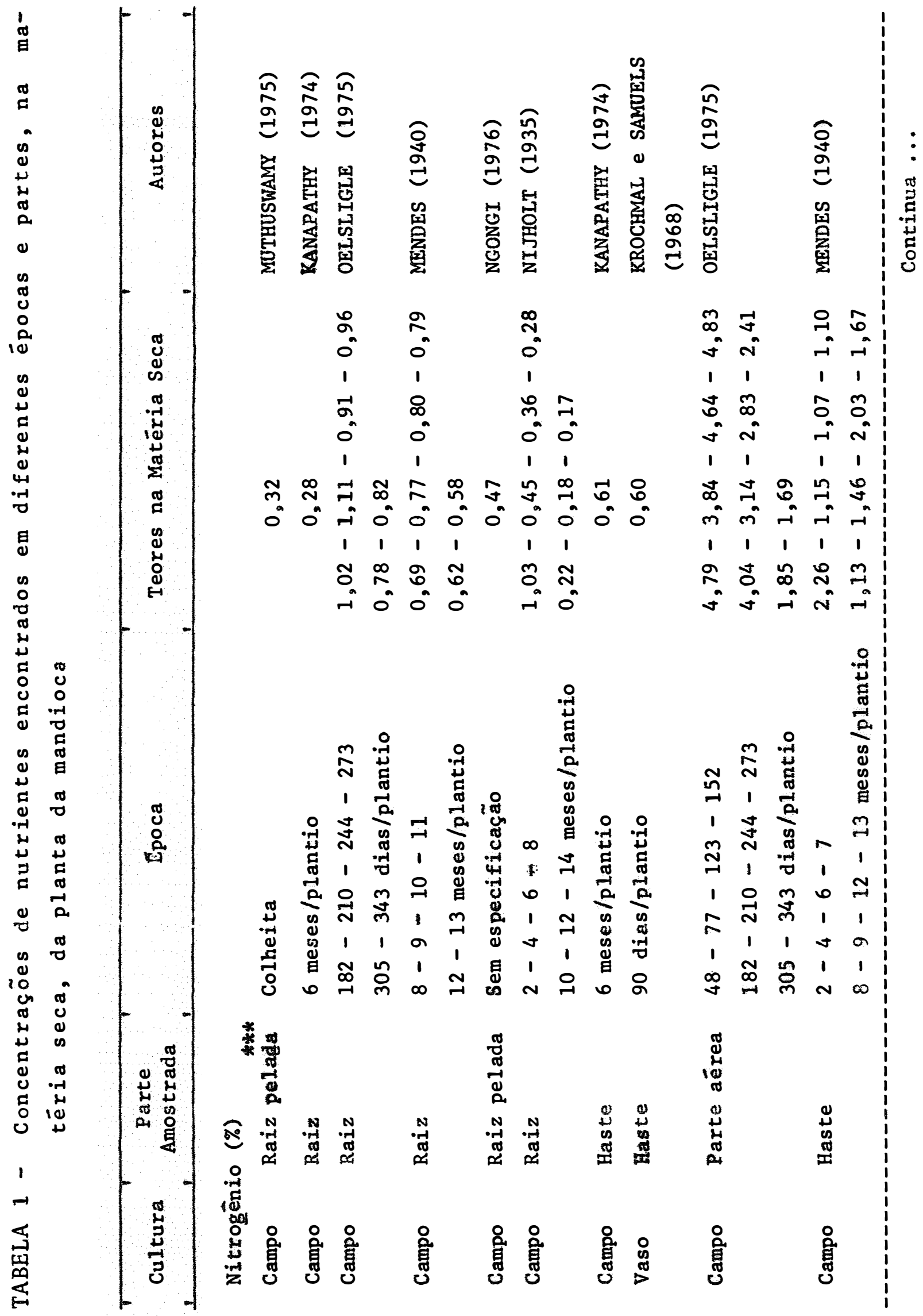




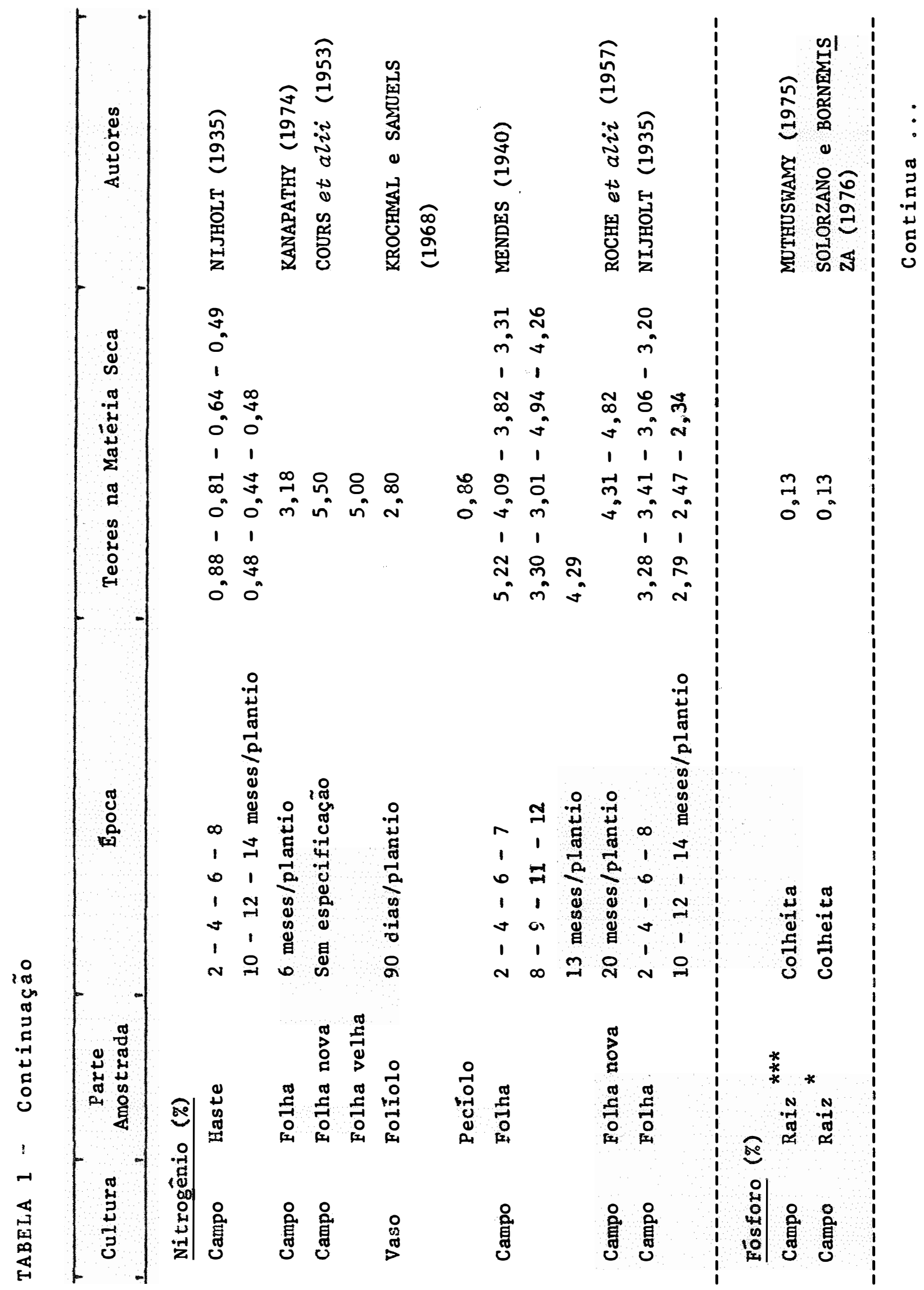




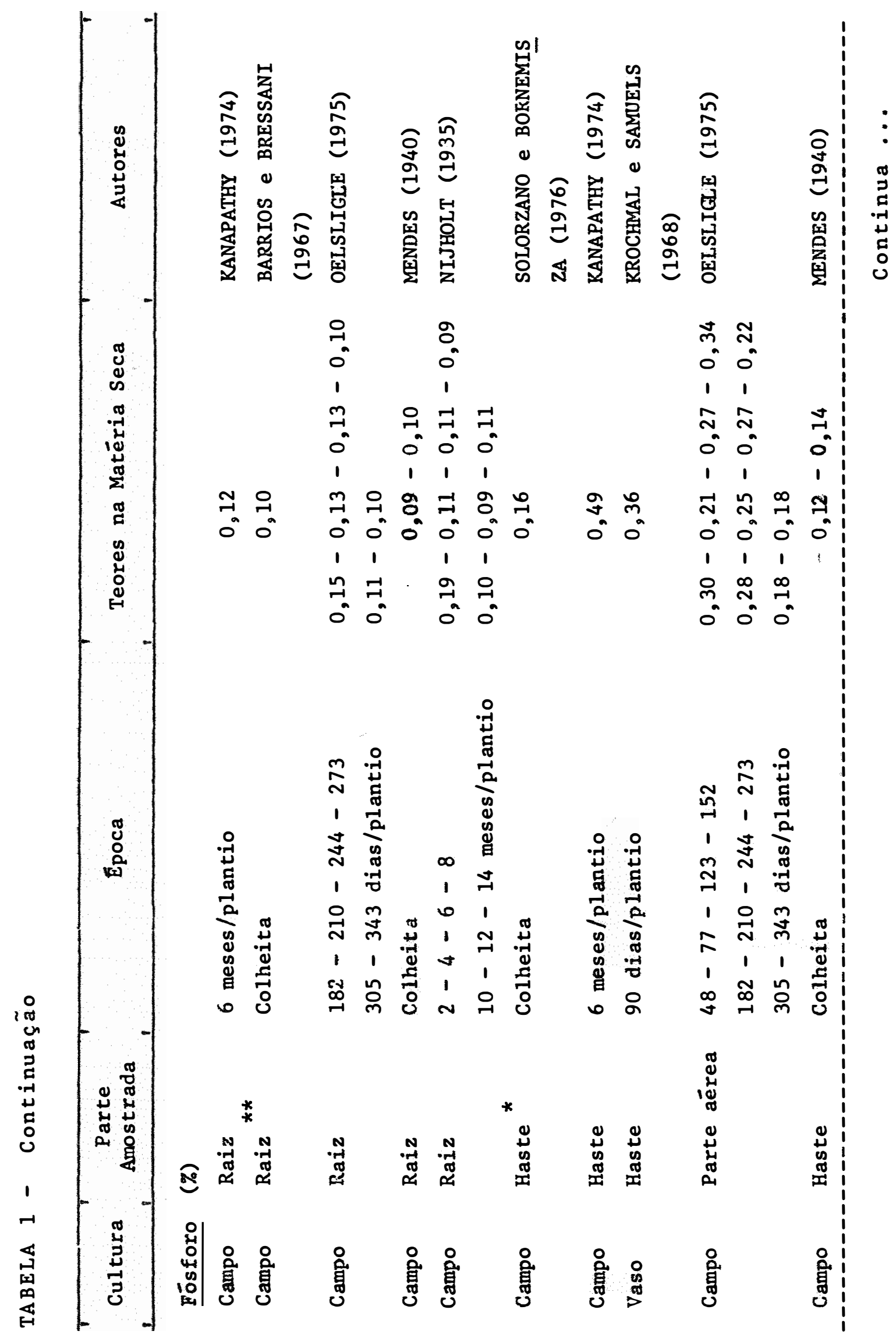




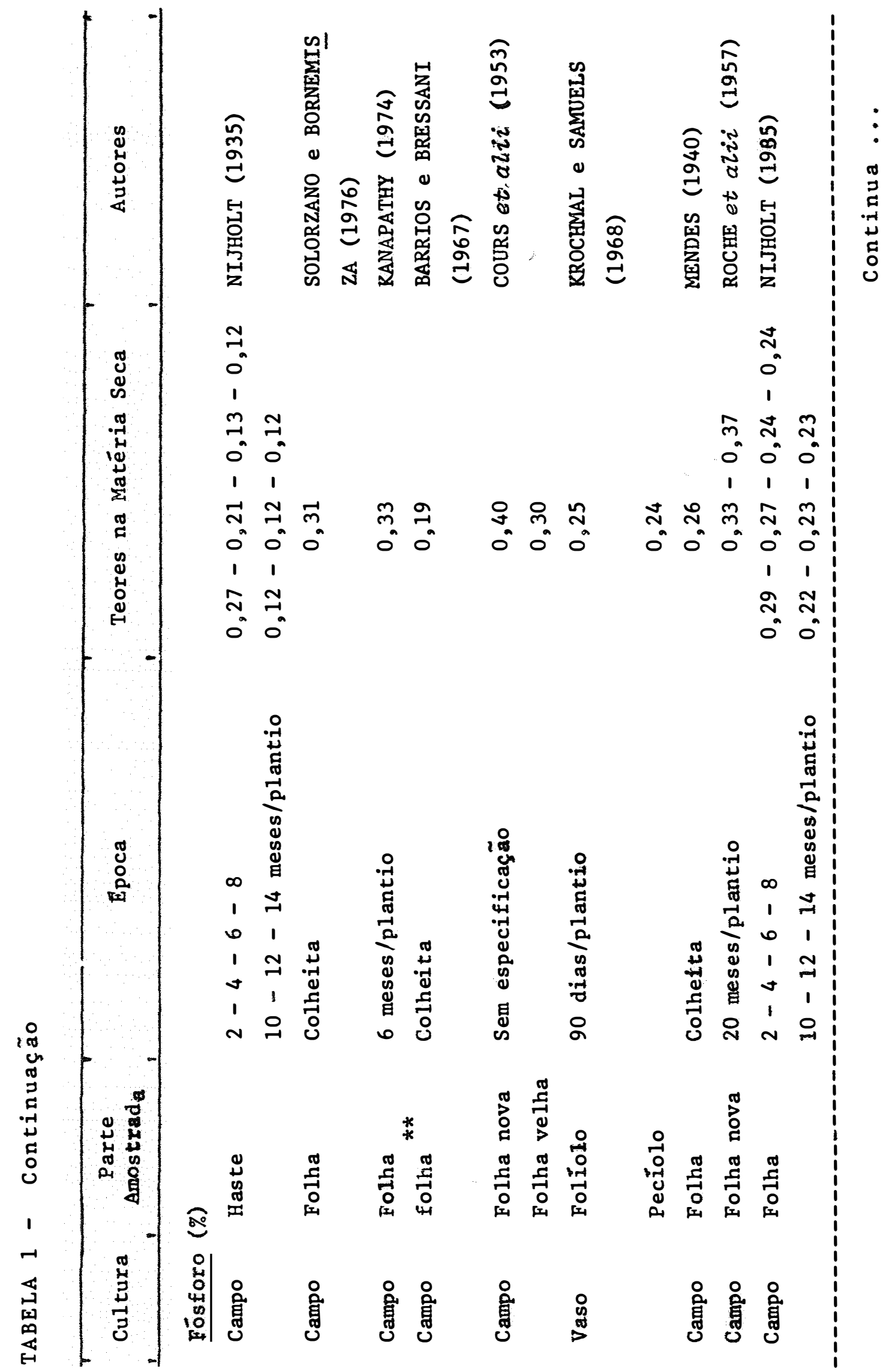




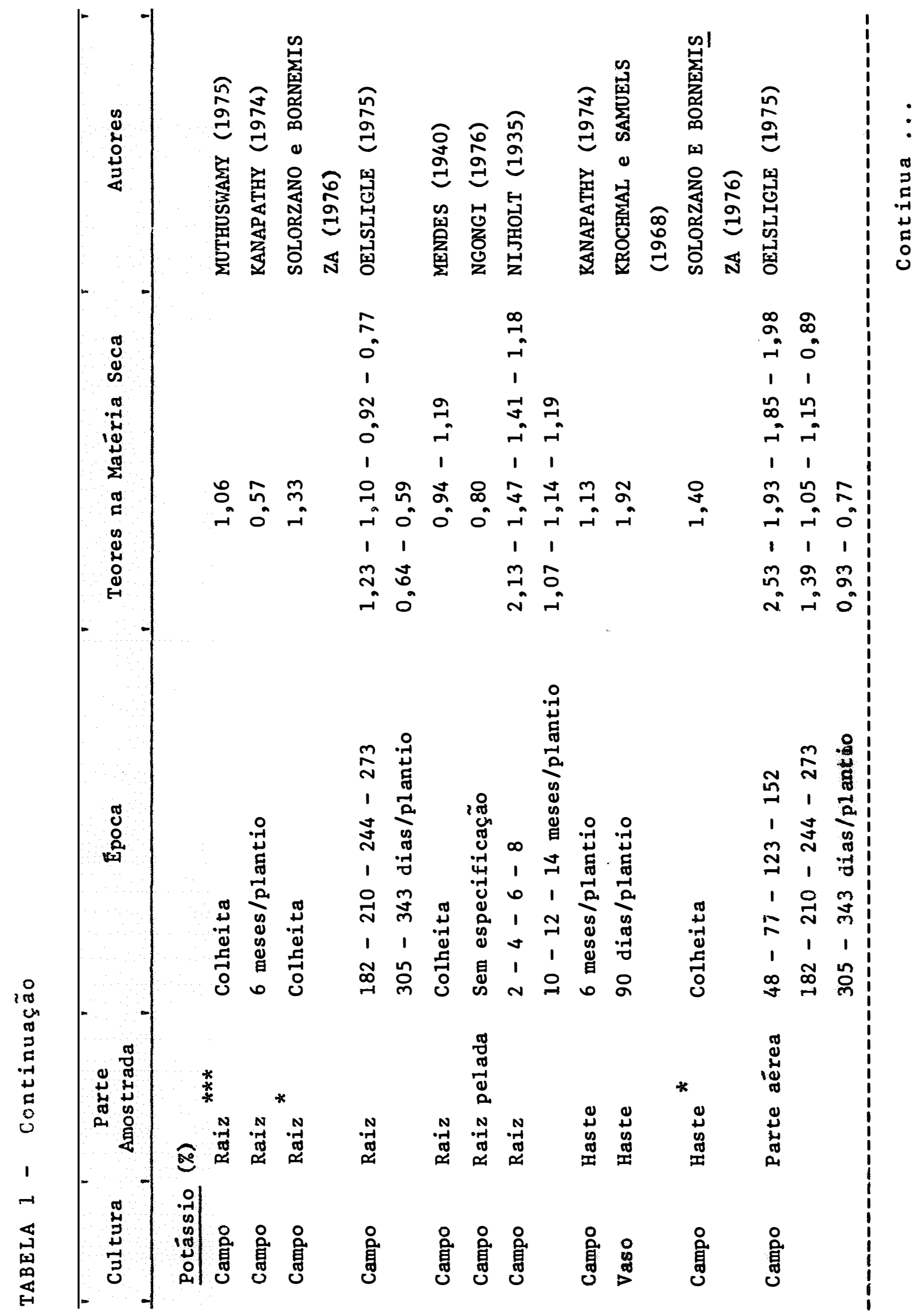




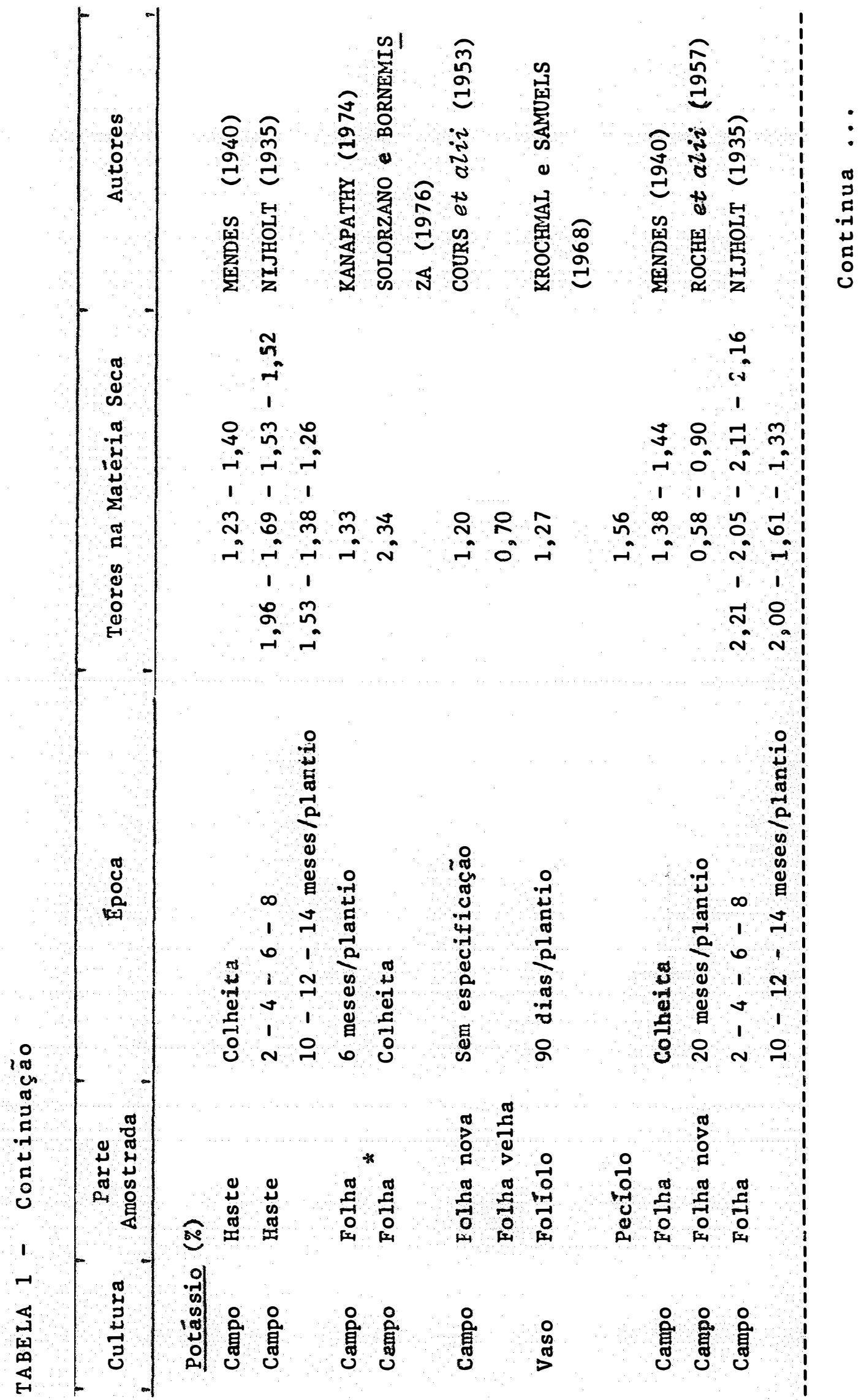




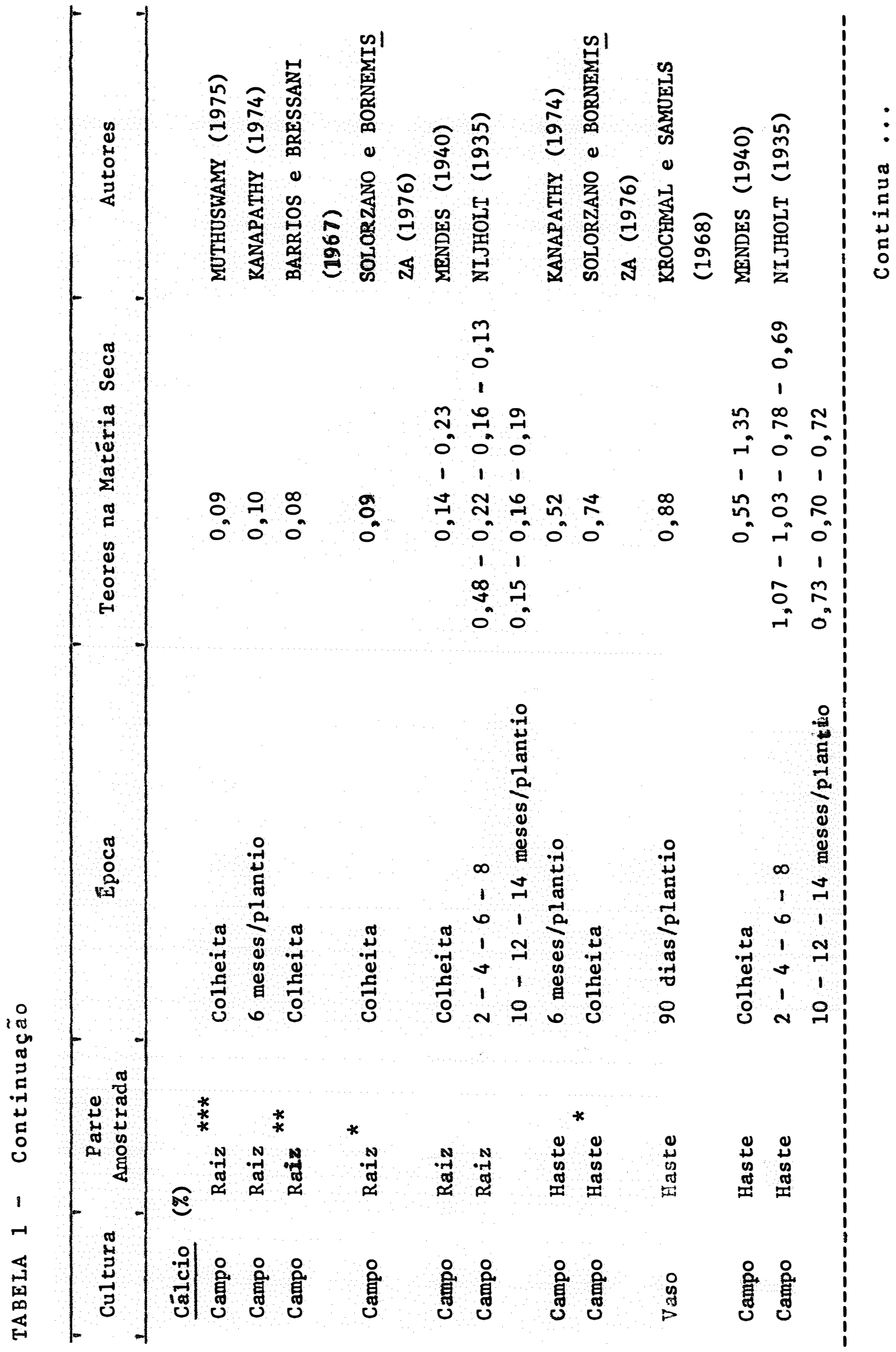




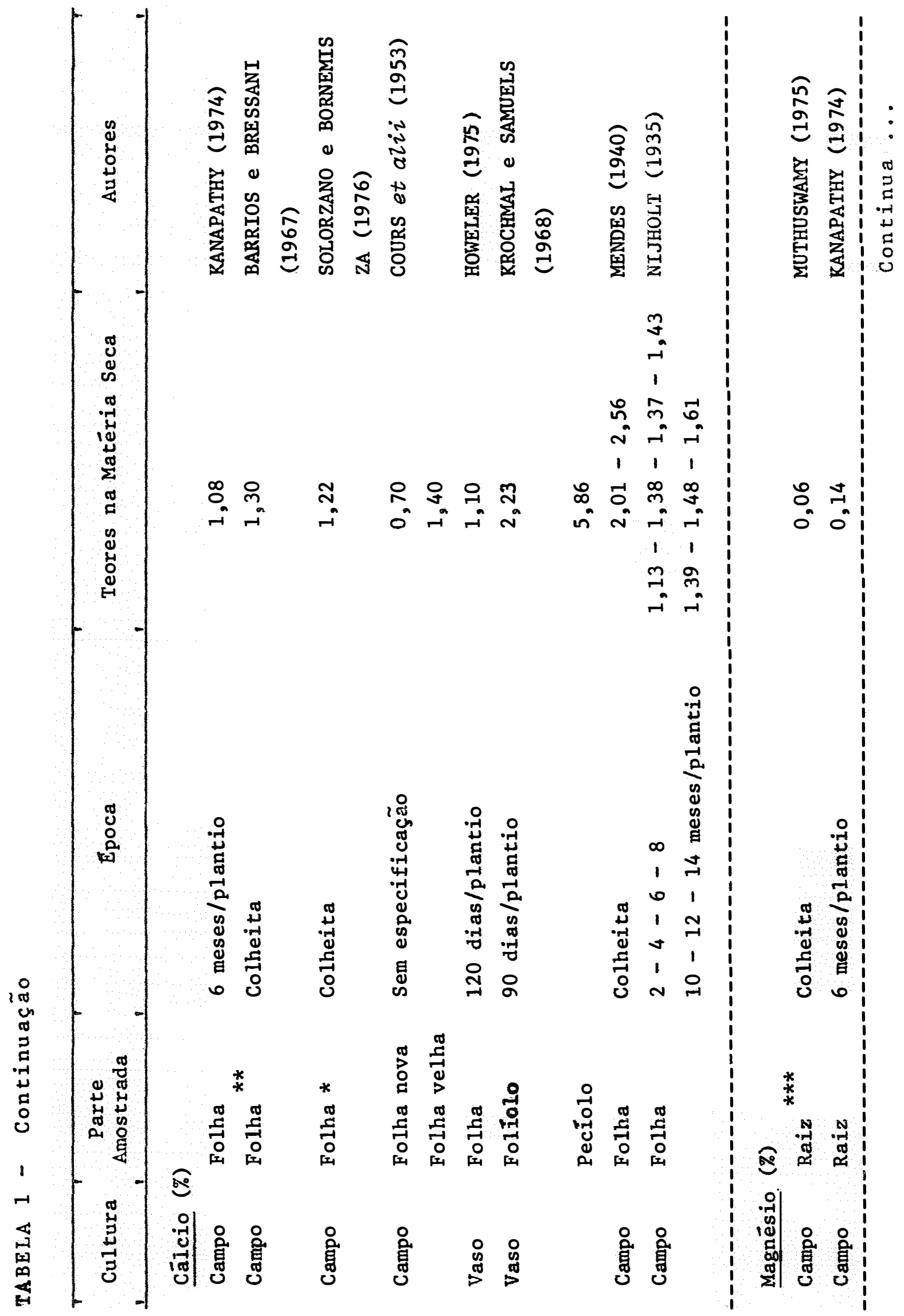




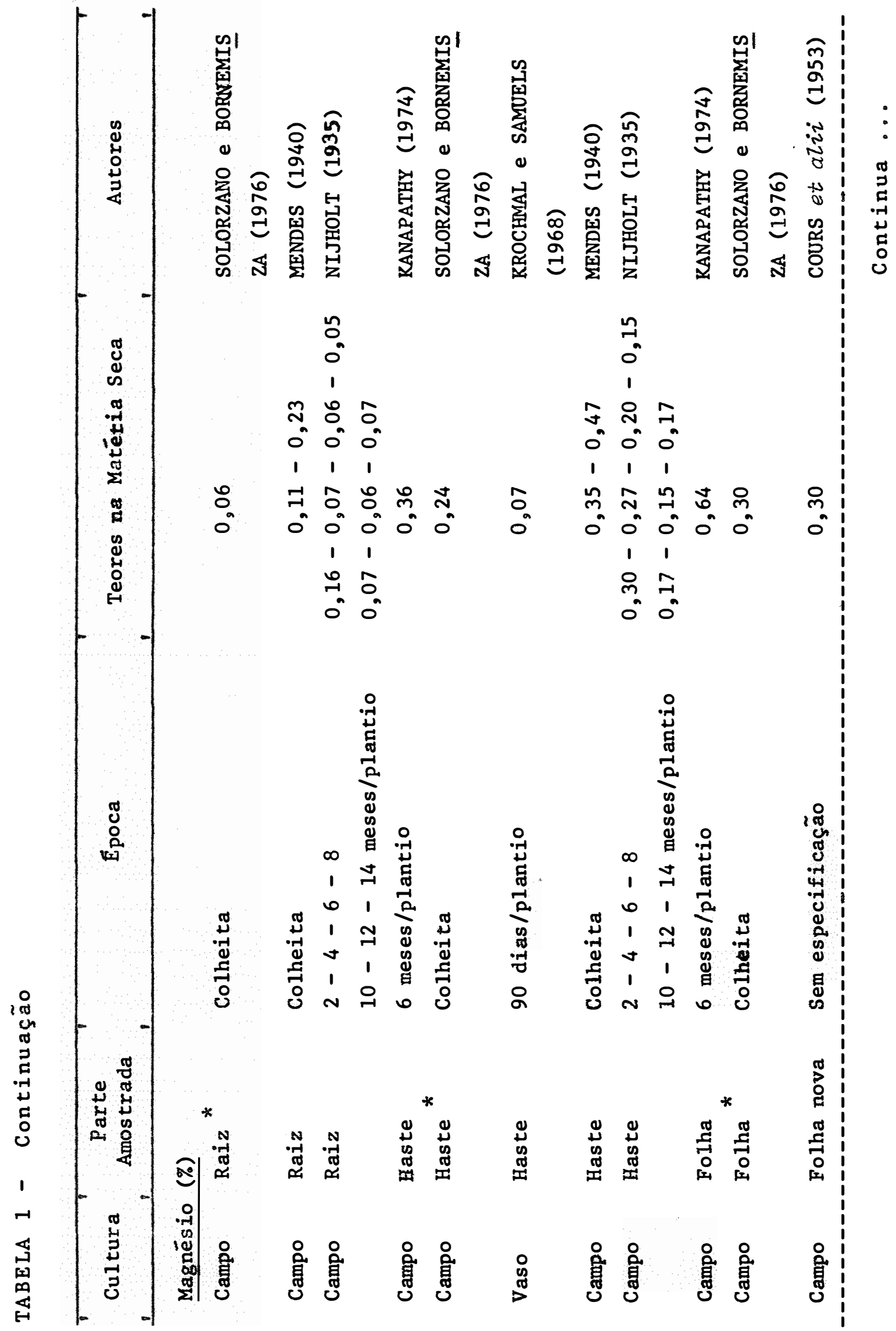




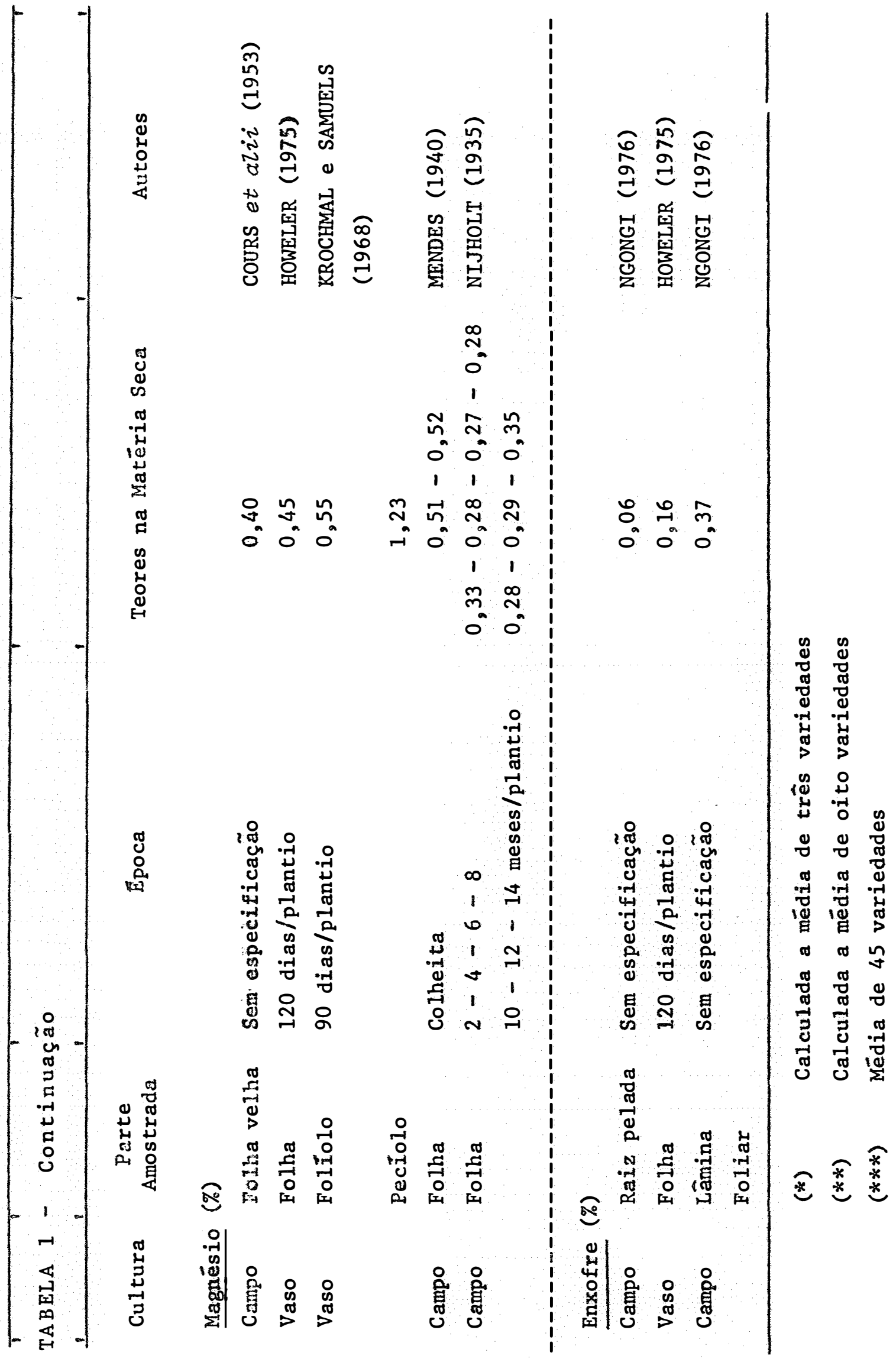




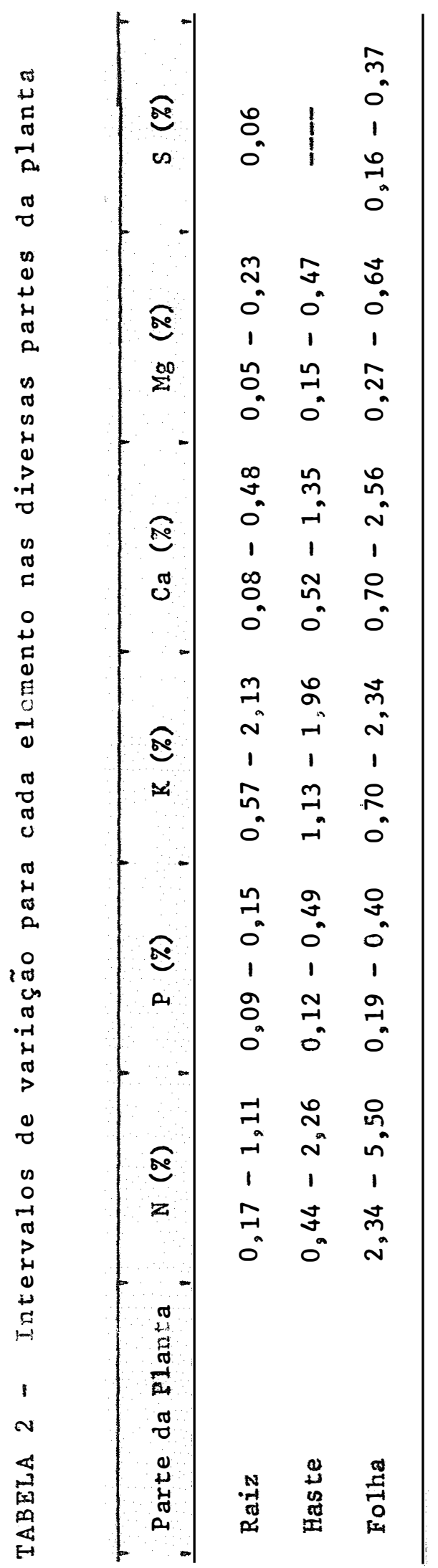




\section{2 - Extração e Exportação de Nutrientes}

Na Tabela 3 são apresentadas as amplitudes de variação da extração de nutrientes pela planta inteira correspondente a produção de 1 (uma) tonelada de raízes e da extração de nutrientes somente pelas raízes, ou seja, as quantida des exportadas. Estes valores são oriundos dos dados obtidos da literatura (Tabelas 4 e 5) que, para facilidade de comparação, foram transformedos para quilos por tonelada de raizes.

TABELA 3 - Extração e exportação de nutrientes por uma tonelada de raízes de mandioca, em $\mathrm{kg}$

\begin{tabular}{lccccc}
\hline Elementos & Extração & Média & Exportação & Média \\
\hline Nitrogēnio & $1,93-20,10$ & 6,78 & $0,70-6,85$ & 2,22 \\
Fósforo & $6,67-2,40$ & 1,33 & $0,29-0,77$ & 0,48 \\
Potássio & $4,69-14,96$ & 7,28 & $1,77-7,14$ & 3,51 \\
Cálcio & $1,00-2,90$ & 3,51 & $0,28-1,34$ & 0,66 \\
Magnésio & $0,46-2,20$ & 1,19 & $0,05-1,08$ & 0,39 \\
\hline
\end{tabular}

Verificam-se diferenças acentuadas nos dados obtidos pelos diversos autores, as quais são devidas, principalmente, por terem trabalhado com cultivares diferentes e condições variadas de clima, solo e tratos culturais. 


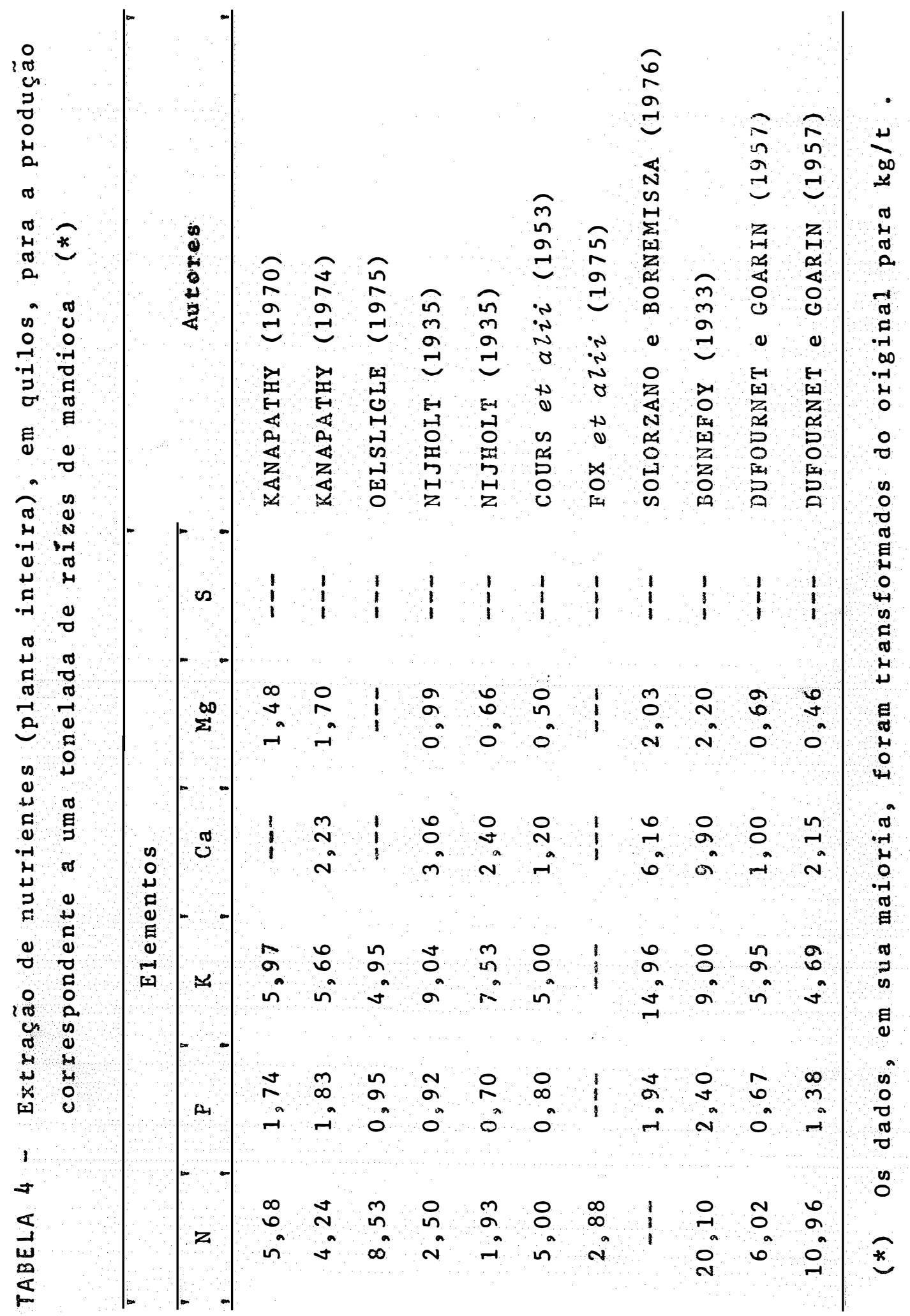




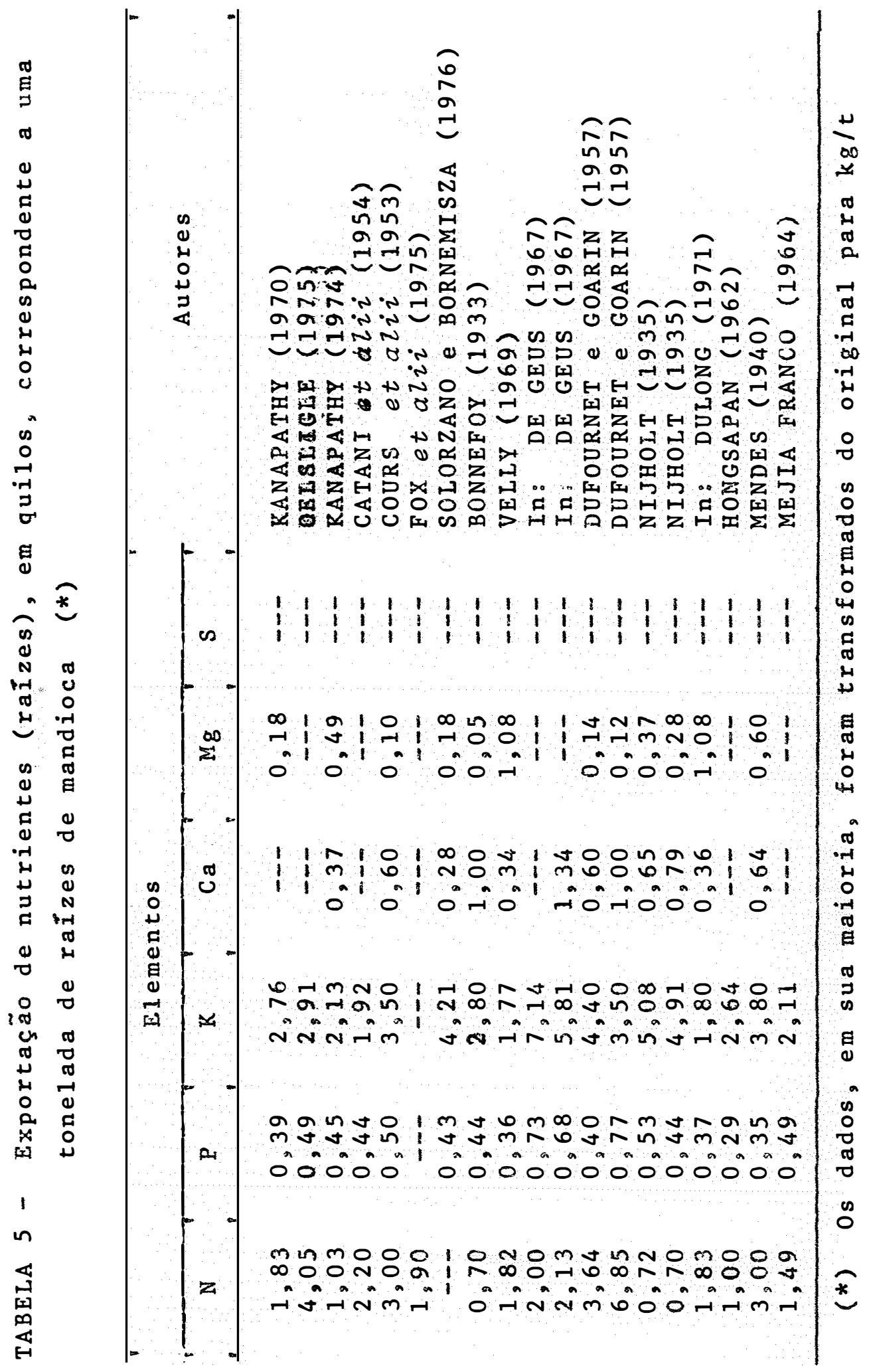


4 - MATERIAL E METODOS

Foram utilizadas as cultivares de mandioca (Manihot esculenta, Crantz) Branca de Santa Catarina e IAC Mantiqueira, a primeira foi introduzida e, a segunda, criada e selecionada pela Seção de Raízes e Tubérculos do Instituto Agronômico de Cam pinas, SP. A descrição geral dessas cultivares é a seguinte:

\section{Branca de Santa Catarina}

Introduzida do Estado de Santa Catarina em 1935. Planta de porte alto, folhas largas com 3 ou 5 lobos, hastes maduras claras e brotos novos vermelhos, película suberosa da raiz clara, lisa com anéis arroxeados, córtex branco e polpa branca. Considerada mandioca brava ou tóxica, contendo em média 300 ppm de ácido cianídrico na polpa fresca. 
Mantiqueira (IAC 24-2)

Obtida por cruzamento aberto em 1956. Planta de por te alto, folhas largas com 7 , 8 ou 9 lobos, hastes maduras ar roxeadas e brotos novos verde arroxeados, película suberosa da raiz marrom, áspera, córtex externamente arroxeado e polpa bran ca. Considerada mandioca mansa ou aipim, contendo em média 60 ppm de àcido cianídrico na polpa fresca.

0 experimento foi instalado no Centro Experimental de Campinas, do Instituto Agronômico de Campinas, SP, situado à 22:05' Latitude Sul e 47905' Longitude 0este a 669 metros de altitude, cujo clima, segundo a classificação de Köeppen é do tipo C w a (SETZER, 1966).

0 solo do ensaio é classificado como Latossol roxo, cujas características químicas e granulométricas nas profundidades de $0-20,20-40$ e $40-60 \mathrm{~cm}$ acham-se ra Tabela 6 .

Os dados de temperatura média do ar e da distribui ção hỉdrica durante o período estudado e as normais de 20 anos (1956/1976) encontram-se na Tabela 7 .

o experimento foi irrigado duas vezs, uma no início de agosto por ocasião da emergência das plantas e a outra um mês após. A finalidade desta operação foi ga antir bom "stand" e uniformidade das plantas, em virtude da estagem que ocorreu neste periodo (Tabela 7). 
Todos os tratamentos foram adubados com a fórmula $40-80-60 \mathrm{Kg} / \mathrm{ha}$ de $\mathrm{N}, \mathrm{P}_{2} \mathrm{O}_{5}$ e $\mathrm{K}_{2} \mathrm{O}$, respectivamente. 0 nitro gênio, na forma de sulfato de amoneo, foi aplicado somente em cobertura aos 60 dias após a brotação. 0 fósforo e o potássio, nas formas de superfosfato simples e cloreto de potássio, respectivamente, foram aplicados nos sulcos de plantio e misturados com a terra.

As manivas de ambas as cultivares provieram da Estação Experimental de Piracicaba, SP, as quais receberam os mesmos tratos culturais e apresentavam-se sadias e com cerca de um ano de idade. Foram cortadas com serra circular no tamanho de $25 \mathrm{~cm}$ e plantadas pelo sistema comum, horizontalmente, no espaçamento de $1,0 \times 0,6 \mathrm{~m}$. As parcelas forém constituídas de 108 plantas cada, compostas de 9 1inhas de 12 plantas.

As amostragens das plantas foram feitas em 6 ëpocas do desenvolvimento colhendo-se 3 plantas inteiras por repeti ção, devidamente circundadas por plantas competitivas. A primeira amostragem foi feita 60 dias após a brotação e as outras a intervalos de 60 dias até o fim do primeiro ciclo vegetati vo.

Informações mais detalhadas à respeito das cultiva res por ocasião das amostragens encontram-se na Tabela 8 .

Após a coleta, as plantas foram separadas nas partes: folhas (foliolos + peciolos), hastes e raizes tuberosas. As amostras foram pesadas, lavadas, secas e moidas segundo SAR RUGE e HAAG (1974). 
As análises químicas foram efetuadas na seção de Quí mica Analitica do Instituto Agronômico, Campinas, SP, de acordo com os seguintes métodos: N e P pelo Autoanalisador II TECH NICON, a partir de amostras digeridas segundo CONCON e SOLTESS (1973), sendo o P pelo método colorimétrico do ácido fosfovana domolíbdico - amarelo (LOTT et alii, 1956) e o N pelo fenol al calino (GEHRKE et $a Z_{i} i, 1973$ ); S pelo Autoanalisador II TECHNICON segundo TEIXEIRA et $a \tau_{i} i$ (1976); Ca e Mg (BATAGLIA e GALLO, 1972) e K (PERKIN-ELMER, 1971).

0 delineamento estatístico adotado foi o de blocos ao acaso com 2 (dois) tratamentos e 4 (quatro) repetições, dis postos em parcelas subdivididas para 6 (seis) épocas de colbei ta (GOMES; 1973).

Deste modo, procedeu-se a anālise de variância, incluindo todas as épocas amostradas, para matéria seca total (raizes, hastes e folhas), matéria seca e fresca das raízes am bas em gramas por planta e para os nutrientes $\mathrm{N}, \mathrm{P}, \mathrm{K}, \mathrm{Ca}$, $\mathrm{Mg}$ e $\mathrm{S}$, em miligramas por plánta, contidos nas raízes e na planta inteira.

As equações de regressão assim como os respectivos pontos de máximo e de inflexão, quando couberam, foram calcula das para as quantidades acumuladas de matéria seca total, maté ria seca e frescas das raízes e $N, P, K, C a, M g$ e $S$ na plan ta inteira e raỉes, pelas cultivares em funçẽo do tempo. 
29.

A escolha da curva de regressão recaiu sobre aquela de maior grau, até o 49 grau, cujo componente mais elevado foi significativo ao nível de $5 \%$ de probabilidade. Para determinar o ponto de máximo foram obtidas as raízes da equação difé rencial de primeira ordem e a quantidade máxima foi calculada pela substituição desse valor na equação principal. 0 ponto de inflexão foi obtido pela resolução da diferencial de segun da ordem. 


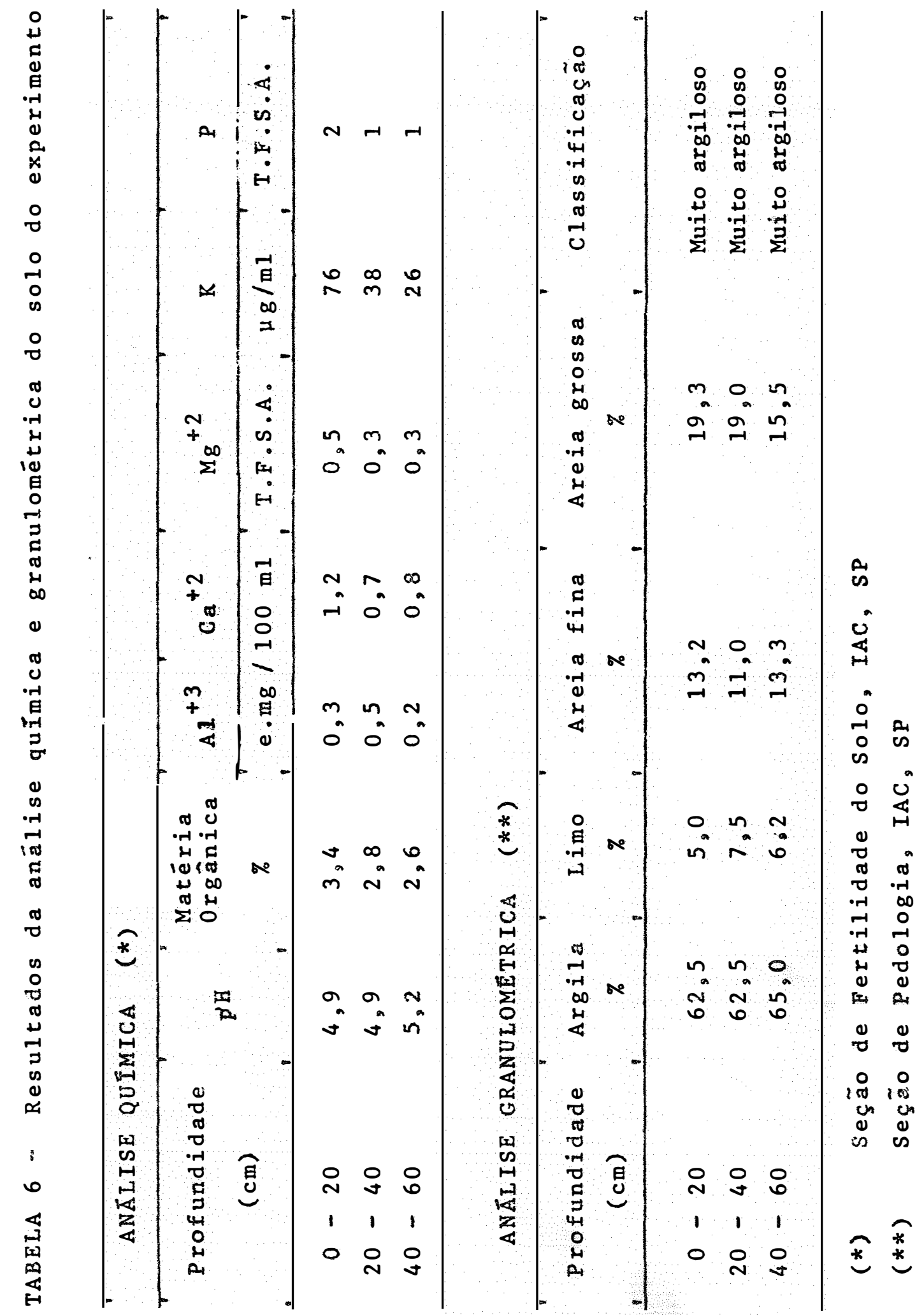


TABELA 7 - Temperatura média do ar e distribuição hídrica no Centro Experimental de Campinas, IAC, SP, nos meses de execução do experimento (*)

\begin{tabular}{|c|c|c|c|c|}
\hline \multirow[b]{2}{*}{ Meses } & \multicolumn{2}{|c|}{ Precipitação natural } & \multicolumn{2}{|c|}{ Temperatura } \\
\hline & $\begin{array}{c}\text { Média de } \\
20 \text { anos } \\
(\mathrm{mm})\end{array}$ & $\begin{array}{c}75 / 76 \\
(\mathrm{~mm})\end{array}$ & $\begin{array}{l}\text { Média de } \\
20 \text { anos } \\
\text { (OC) }\end{array}$ & $\begin{array}{r}75 / 76 \\
(8 C)\end{array}$ \\
\hline Ju 1 ho & 33,4 & 39,4 & 17,2 & 15,7 \\
\hline Agosto & 35,0 & 0,0 & 18,9 & 21,3 \\
\hline Setembro & 57,4 & 23,9 & 20,7 & 21,5 \\
\hline Outubro & 139,0 & 214,9 & 21,2 & 21,0 \\
\hline Novembro & 136,9 & 252,2 & 21,8 & 21,2 \\
\hline Dezembro & 214,0 & 181,0 & 22,5 & 23,1 \\
\hline Janeiro & 240,5 & 261,5 & 23,1 & 23,1 \\
\hline Fevereiro & 216,0 & 276,4 & 23,0 & 21,6 \\
\hline Março & 132,8 & 166,6 & 22,6 & 22,5 \\
\hline Abril & 61,3 & 84,7 & 20,8 & 20,4 \\
\hline Maio & 50,3 & 151,1 & 18,2 & 17,8 \\
\hline Junho & 44,9 & 86,1 & 17,2 & 16,5 \\
\hline Ju1ho & -- & 138,7 & --- & 16,1 \\
\hline Agosto & -- & 105,3 & --- & 18,3 \\
\hline Setembro & -- & 182,3 & -- & 18,3 \\
\hline
\end{tabular}

(*) Seção de Climatologia Agrícola, IAC, SP 


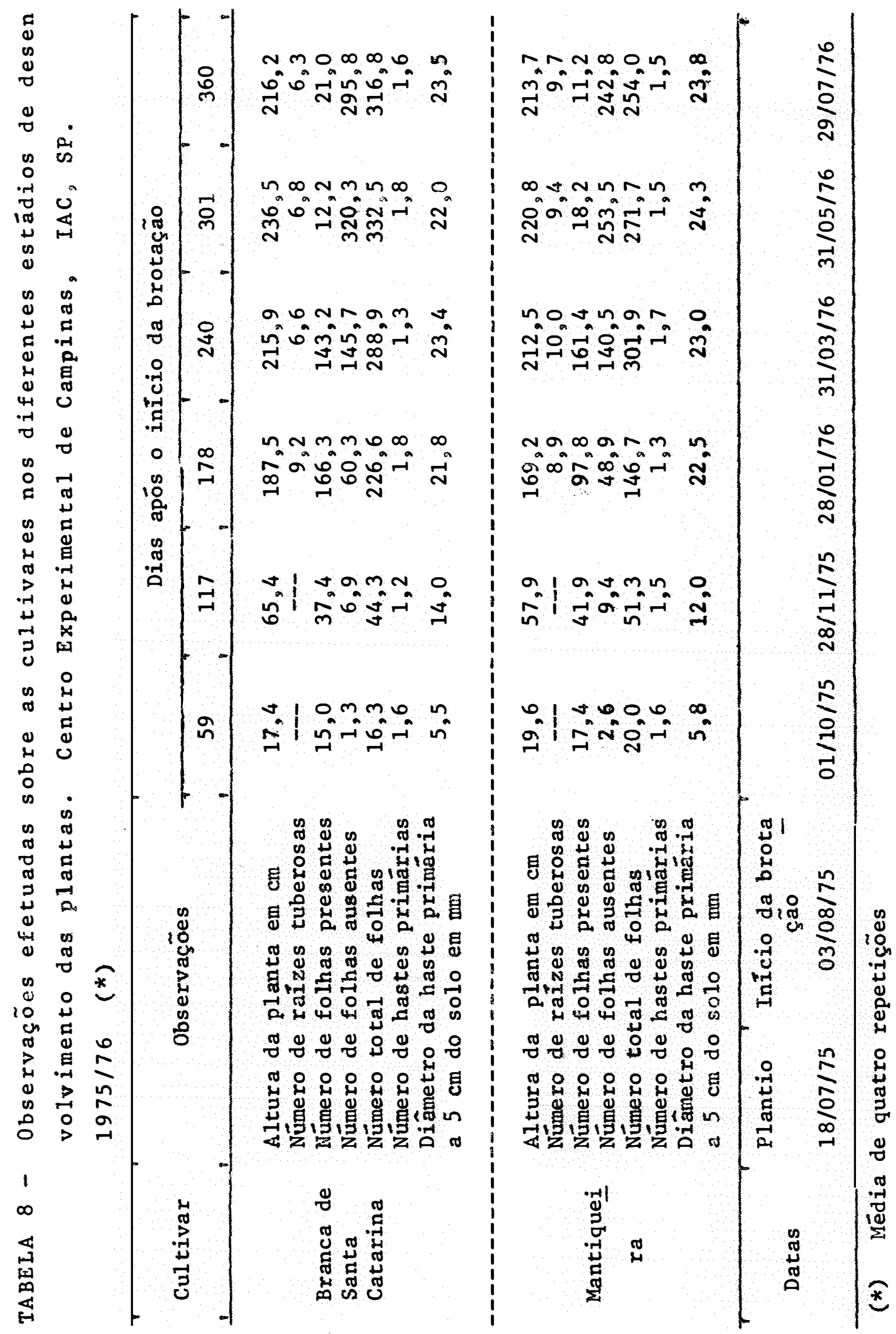


$5.1-\underline{\text { Crescimento }}$

Na Tabela 9 são apresentados os dados referentes à a cumulação de matéria seca nos órgãos das cultivares em função do crescimento.

A anālise da variância foi conduzida para a produção da planta inteira e para a produção de raízes e os resultados constam da Tabela 10 .

Verifica-se que houve diferença significativa na pro dução de matéria seca das raízes, sendo a cultivar Mantiqueira mais produtiva que a outra. A interação cultivar z época também foi significativa ao nível de $5 \%$ de probabilidade o que in 
dica que as cultivares comportaram-se diferentemente em rela ção as épocas de acumulação de matéria seca nas raízes. Quando se considera a planta inteira não se observa diferença entre as cultivares, isto ocorreu, provavelmente, porque a culti var Branca de Santa Catarina produziu mais parte aérea (hastes + folhas) que a Mantiqueira, compensando a diferença na produção de raízes.

As curvas de regressão ajustadas recaíram, para as duas cultivares, em equações de 29 grau para as raízes e 49 grau para a planta inteira (Figura 1).

Na Tabela 11 são apresentados para as duas cultiva res o ponto de mäximo, em dias, e a respectiva quantidade e o ponto de inflexão, correspondente à época em que a taxa de acu mulação passa a ser mäxima, obtidos através das equações ajustadas. A cultivar Mantiqueira atingiu o ponto de máximo, para a planta inteira e raízes, antes da Branca de Santa Catarina, evidenciando ser mais precoce que esta.

A marcha de acumulação, ressalvando as variações devido a condição de clima, solo, tratos culturais e cultivar em pregado, está de acordo com NIJHOLT (1935); ORIOLI (1967) e OELSLIGLE (1975).

As duas cultivares atingiram o ponto de inflexão na mesma época (161 dias) spara a acumulação de matéria seca total. Assim, no período de 120 a 180 dias acumularam em média 114,2 e $95,7 \mathrm{~kg} / \mathrm{ha} / \mathrm{dia}$ e no período de 180 a $240 \mathrm{dias,} 88,5$ e $76,9 \mathrm{Kg} / \mathrm{ha} / \mathrm{dia}$, respectivamente, para as cultivares Mantiquei- 
ra e Branca de Santa Catarina. Estes períodos corresponderam aos meses de dezembro a março que normalmente apresentam alta precipitação pluviométrica e temperatura (Tabela 7) concorren do para o elevado desenvolvimento vegetativo da mandioca. A taxa de acumulação máxima obtida está de acordo com a encon trada por COURS (1951) de $10-12,5 \mathrm{~g} / \mathrm{m}^{2} / \mathrm{dia}(100-125 \mathrm{Kg} / \mathrm{ha}$ (dia) de matéria seca.

A mandioca, à medida que cresce, perde gradativamen te suas folhas em função de fatores ambientais e fisiológicos (MENDES, 1940 ; COURS, $1951 ;$ VIEGAS, 1976). Nas condições do Estado de São Paulo ela chega a ficar totalmente desfolhada na época mais fria e seca do ano. Em virtude da queda gra dativa das folhas torna-se difícil avaliar a produção real de matéria seca. Pelos dados das Tabelas 8 e 9 e considerando o peso seco das folhas caídas igual ao peso seco das folhas pre sentes obteríamos uma taxa máxima aproximada para o cultivar Mantinqueira de 12,7 e $11,7 \mathrm{~g} / \mathrm{m}^{2} / \mathrm{dia}$ nos períodos de 120 a 180 e 180 a 240 dias, respectivamente, bem abaixo, portanto, de 20 g/ha/dia que HuNT et alii (1977) acham ser possível quando se considera a perda de folhas e cultivo sob boas condições climàticas e edāficas.

A queda que pode ocorrer, no final do ciclo, na matēria seca das raízes, bastante evidente na cultivar Mantiqueira, $\vec{e}$ devida, provavelmente, a mobilização do amido ppaza recompor a parte aérea e assim iniciar o segundo ciclo vegeta tivo. 


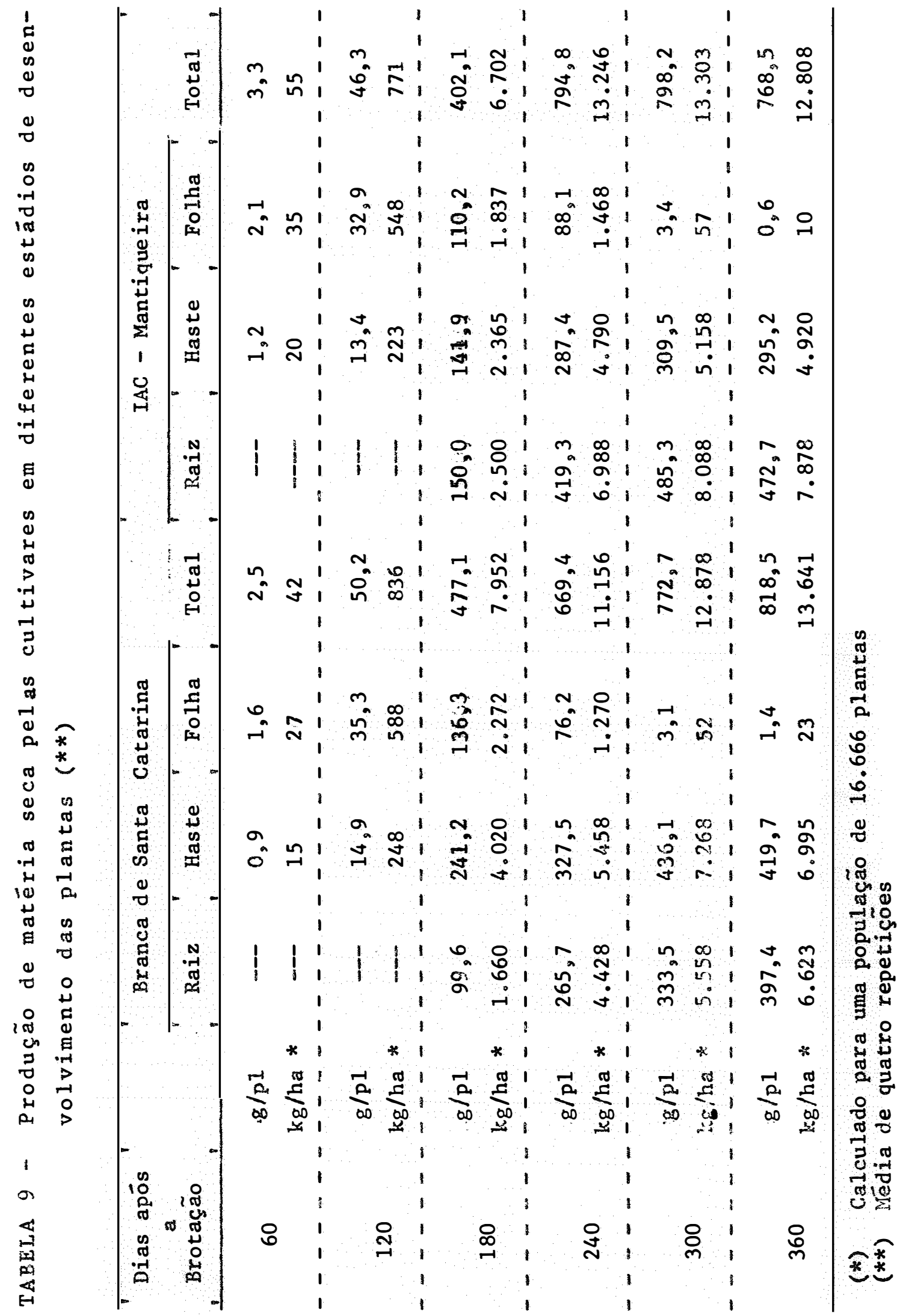




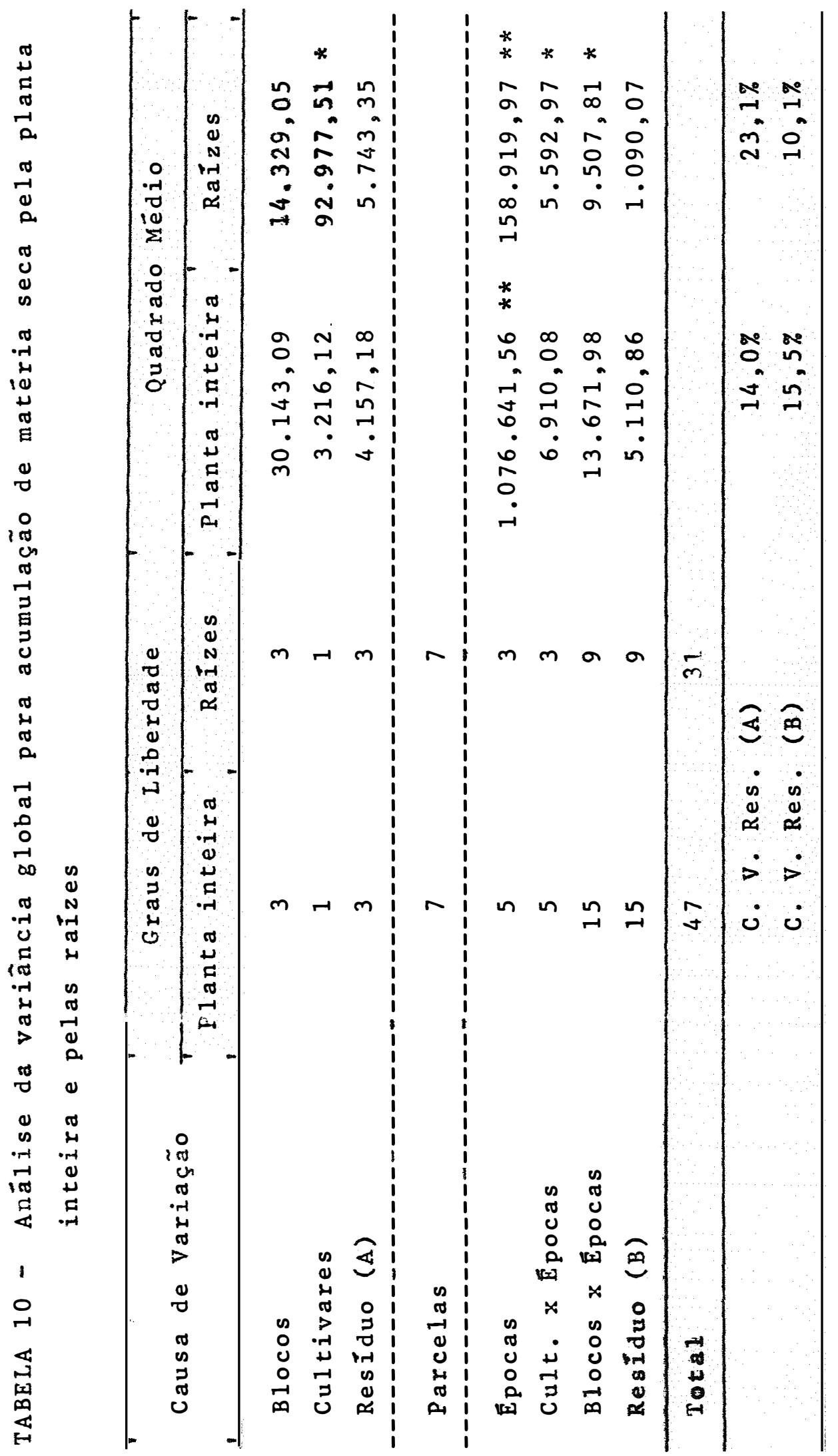




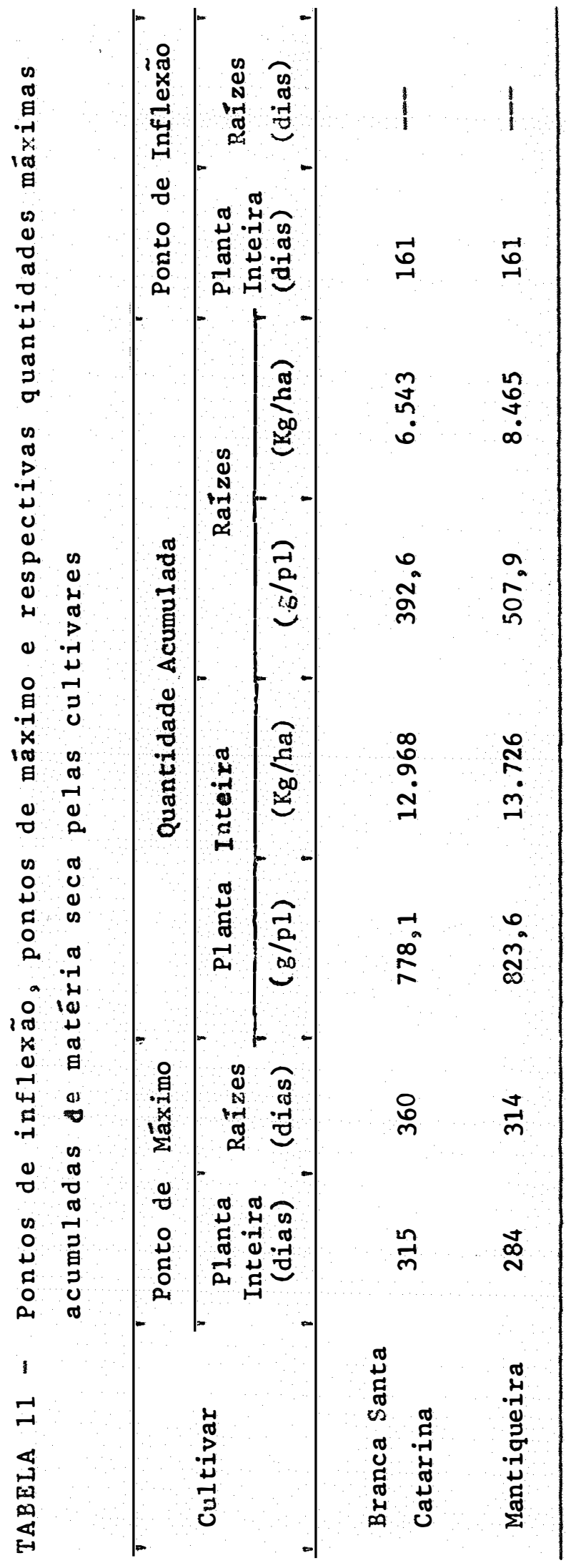




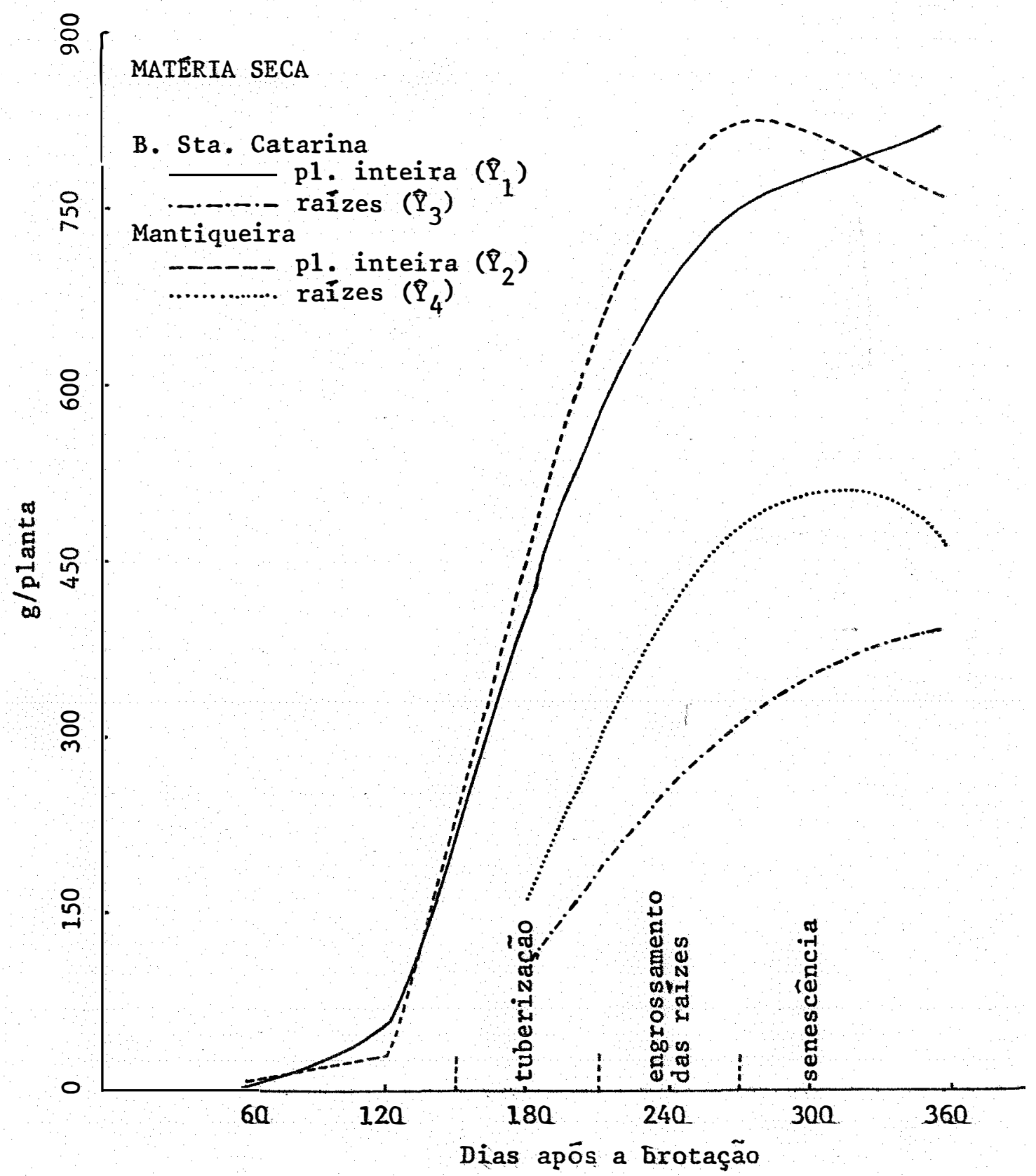

$$
\begin{array}{lr}
\hat{Q}_{1}=854,8-26,2 x+0,24 x^{2}-7,57 \cdot 10^{-4} x^{3}+0,797 \cdot 10^{\top} 6 x^{4}\left(r^{2}=0,99\right) \\
\hat{Q}_{2}=1.175,9-35,2 x+0,32 x^{2}-9,82 \cdot 10^{-4} x^{3}+1,016 \cdot 10^{-6} x^{4}\left(r^{2}=0,99\right) \\
\hat{Q}_{3}=-644,0+5,44 x-0,0071 x^{2} & \left(r^{2}=0,99\right) \\
\hat{Y}_{4}=-1.422,8+12,30 x-0,0196 x^{2} & \left(x^{2}=0,99\right)
\end{array}
$$

Fig. 1 - Curvas de regressão da quantidade de matéria seca $(\hat{Q})$ en função da idade ( $x$ ), na planta inteira e raizes, das cultivares. 


\section{2 - Macronutrientes}

\section{$5.2 .1-$ Nitrogênio}

A concentração e a quantidade de $\mathrm{N}$ acumulada nos diferentes órgãos das cultivares, em função da idade das plantas, são apresentados na Tabela 12 .

A anāilse da variância global mostra que não hà dife renças significativas quanto a acumulação de $N$ pelas cultiva res, quer pela planta inteira ou somente pelas raízes (Tabela 13). Em ambos os casos, a interação cultivar x época também näo foi significativa evidenciando que os mesmos independem da época para absorver diferencialmente o elemento.

As equações ajustadas para acumulação de $\mathrm{N}$ recaíram, pàra as duas cultivares, sobre equações de 29 grau para as raí zes e 4: grau para a planta inteira (Figura 2). Os pontos de máxima acumulação e demanda, obtidos destas equações, constam da Tabela 14.

A acumulação máxima de $N$ nas raízes ocorreu no final do ciclo (360 dias) para ambas as cultivares e em quantidades semelhantes.

A maior demanda de $\mathrm{N}$ pela planta inteira ocorreu ao redor de 126 dias após a brotação e atingiu o máximo acumulado aos 216 dias para ambas as cultivares. Embora a cultivar Bran ca de Santa Catarina acumulou cerca de $20 \mathrm{~kg} / \mathrm{ha}$ de $\mathbb{N}$ a mais que a Mantiqueira esta diferença não foi significativa, provavel - 
mente, devido ao pequeno número de repetições.

A partir do ponto de máximo, a quantidade acumulada cai drasticamente até aos 300 dias, quando então, as plantas encontram-se praticamente desfolhadas. A absorção não cessou, apenas foi excedida pela perda através das folhas. Nesta épo ca a planta entra em "repouso" caracterizado por baixa atividade metabólica.

0 teor de $N$ nas raizes e hastes, aos 300 e 360 dias, sofre ligeira elevação, com mais evidência nas hastes, suge rindo que parte do $N$ contido nas folhas é transferido, antes de sua queda, para estes órgãos elou absorvido do solo e armazenado em virtude da impossibilidade de aproveitamento pela ausência de folhas. Esta deve ser a principal razäo pela retomada da acumulação com a planta preparando-se para entrar no 20 ciclo vegetativo o que aliás é evidenciado pelo teor eleva do de $N$ das folhas novas aos 360 dias. De maneira geral, es te fato aconteceu com todos os nutrientes estudados.

A concentração de $N$ nos órgãos está de acordo com a maioria dos autores citados e obedeceram a seguinte ordem de crescente: folhas, hastes e raizes. As folhas e hastes apre sentaram maior variaçäo na concentração de $N$ entre o início do crescimento e a senescência da planta.

Para efeito de diagnose nutricional, são apresentados a seguir, as variações nos teores de $\mathrm{N}$ das folhas $\mathrm{e}$ hastes, aos 120 dias, época mais próxima da exigência máxima:

Folhas: 5,29 a $5,66 \%$ : Hastes: 1,78 a $1,90 \%$ 


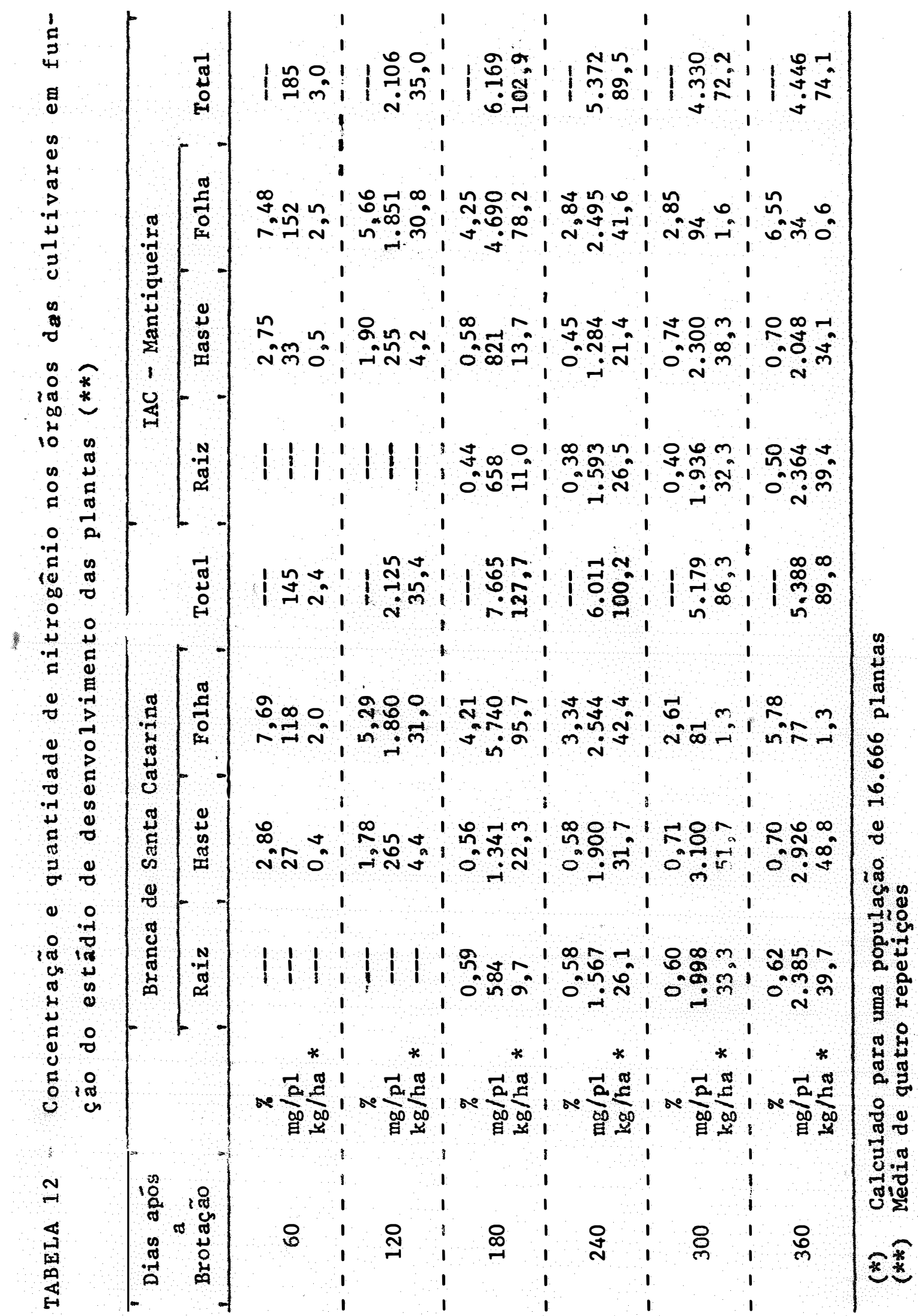




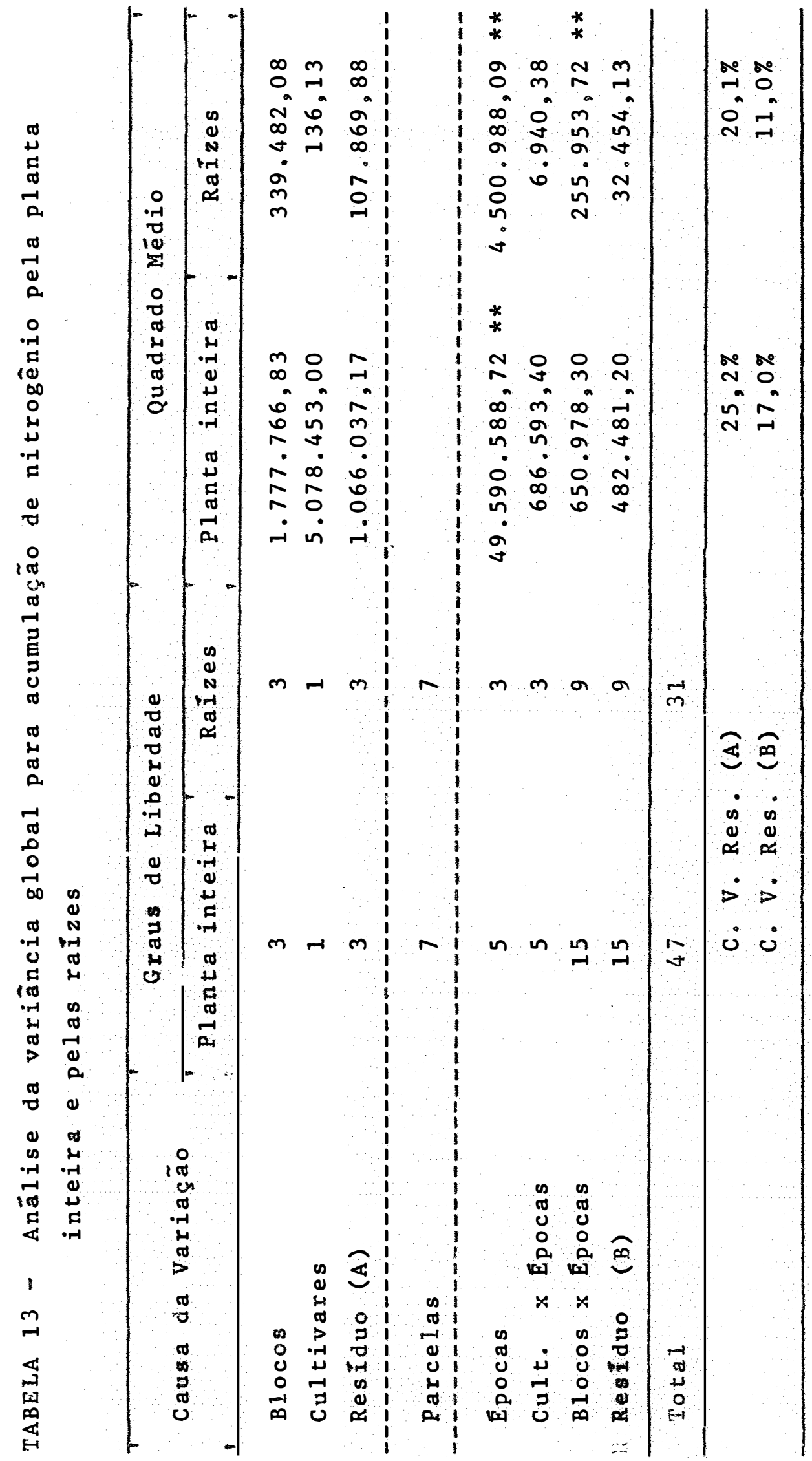


44.

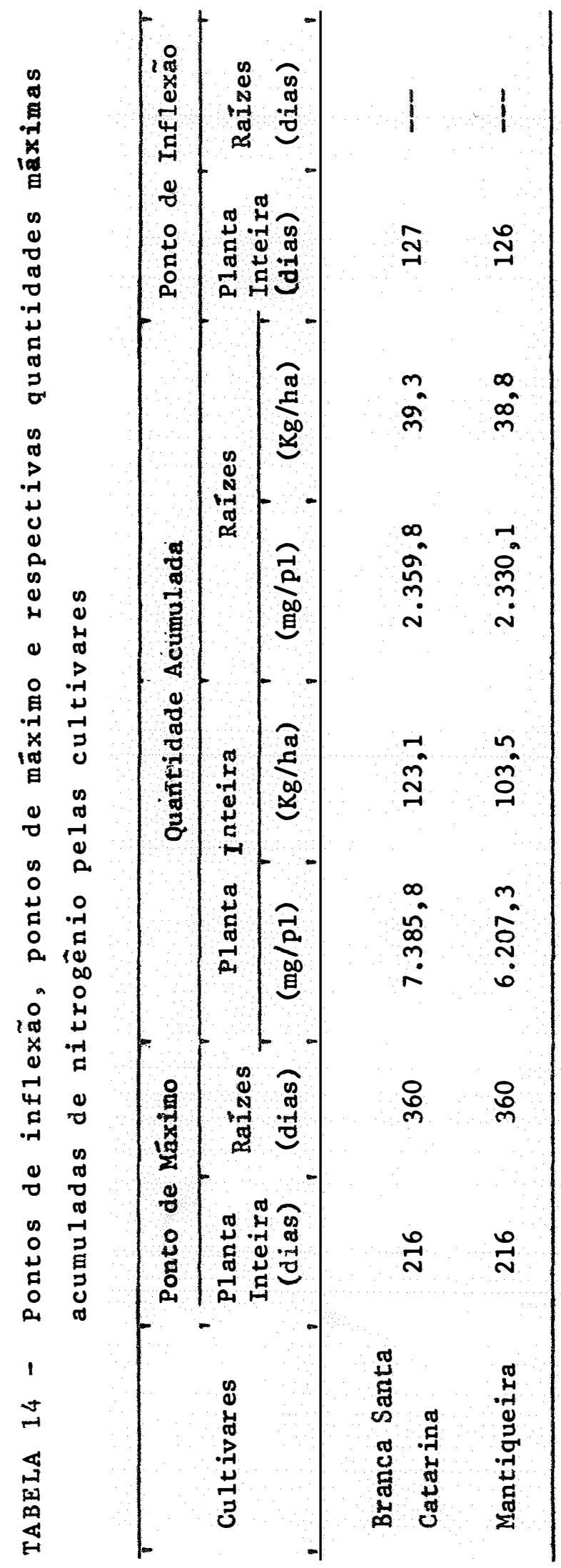




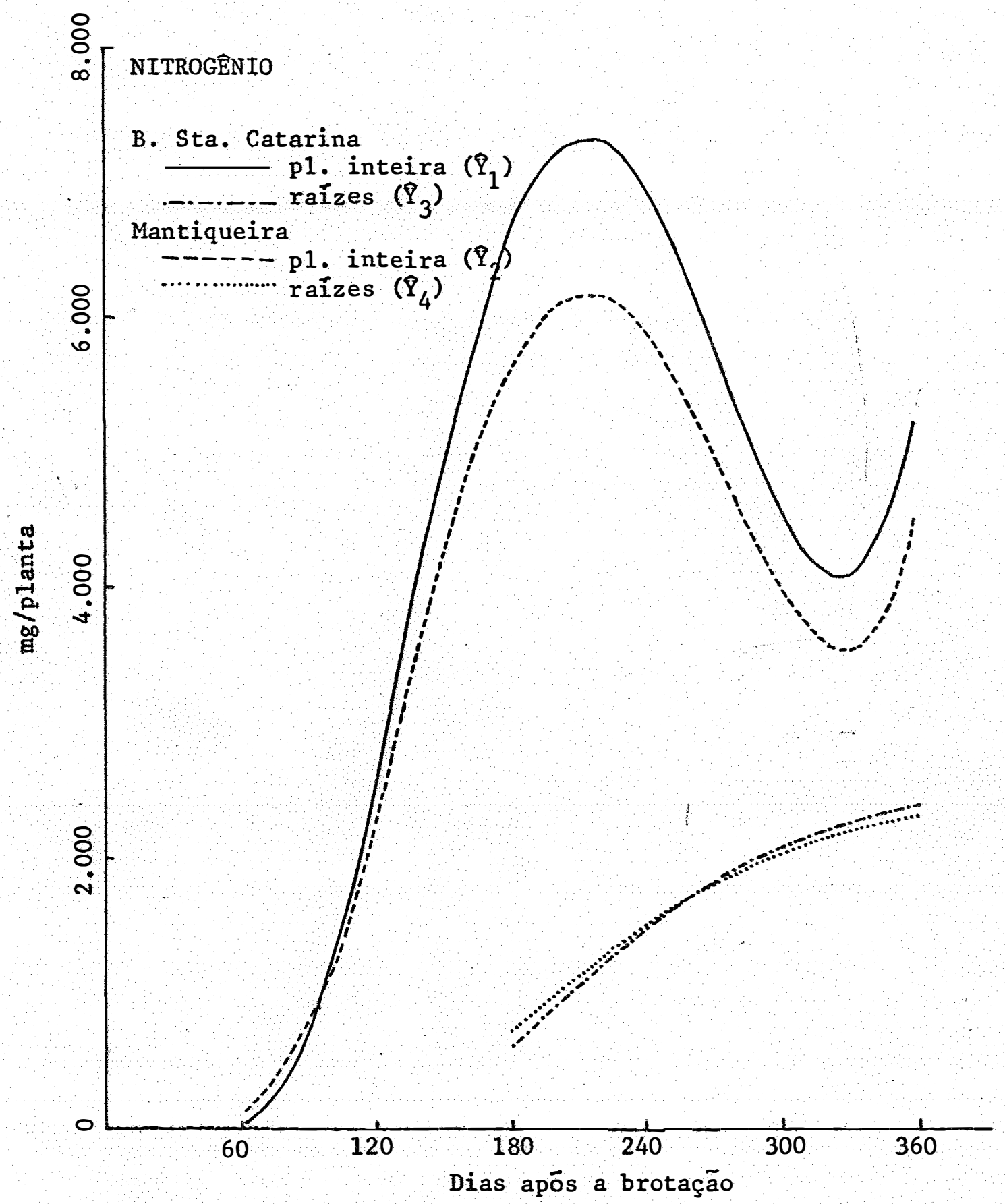

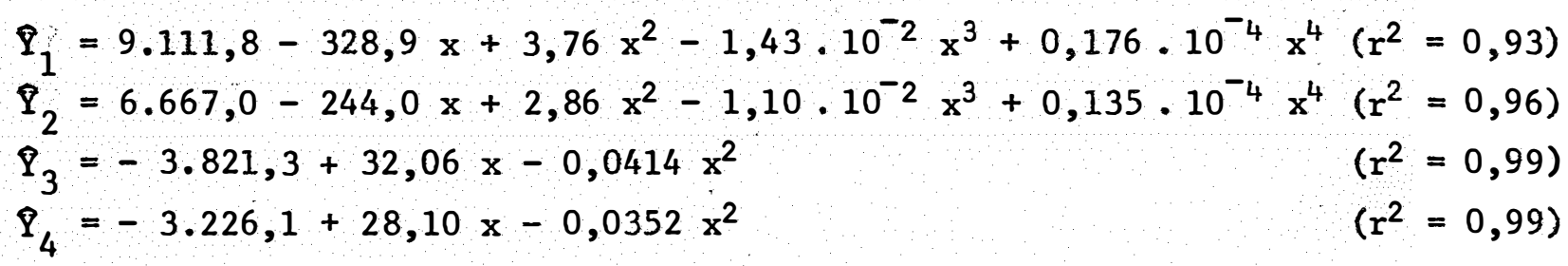

Fig. 2 - Curvas de regressão da quantidade de nitrogênio (Y) em função da idade $(x)$, na planta inteira e raízes, das cultivares. 


\section{$5.2 .2-$ Fósforo}

Os dados referentes à concentração e quantidade de $P$ encontram-se na Tabela 15.

A anālise da variância, incluindo todas as épocas amostradas, para $P$ acumulado nas raízes e na planta inteira acha-se na Tabela 16.

Considerando a planta inteira verifica-se que as cu tivares diferem significativamente quanto a acumulação de $P$. A interação cultivar x época significativa indica dependência dos mesmos em relação a épocas de acumulação. Levando-se em conta o pequeno número de repetições, praticamente, pode-se di zer o mesmo com relação a acumulação de p pelas raízes uma vez que o valor de F calculado $(7,85)$ está próximo do limite de significância $(10,13)$.

Da análise de regressão resultaram equações de 4: grau para a planta inteira e de 29 grau para as raízes. As curvas e as equações acham-se na Figura 3 .

A quantidade máxima de $P$ na planta inteira ocorreu para as duas cultivares em épocas semelhantes, todavia,as quan tidades foram muito diferentes. Com relação a raízes, a culti var Mantiqueira atingiu o ponto de máximo cerca de 45 dias antes da Branca de Santa Catarina, ambas seguindo, de maneira geral, a curva de acumulação de matéria seca. Esses dados e os pontos de inflexão estão expostos na Tabela 17 . 
Pelos dados apresentados verifica-se que a quantidade máxima acumulada de $P$ pelas cultivares é pequena em relação a outros nutrientes e, no entanto, o fósforo tem sido o elemento que mais tem incrementado a produção em ensaios realizados pela Seção de Raízes e Tubérculos (INSTITUTo AGRonôMICo, 19371973). Malavolta et alii (1953) relatam que dos elementos $N$, $P$ e $K$, o $P$ e o que influiu mais fortemente na produção da mandioca e ressaltam a sua importância na fosforilação das re servas de amido nos períodos iniciais do desenvolvimento. Outros autores também tem constatado a importância da adubação fosfatada para a mandioca.

O fato da cultivar Branca de Santa Catarina ser mais exigente em $P$, pelo menos em relação à Mantiqueira, pode explicar em parte os resultados obtidos por MALAVOLTA et alii (1953) e pela Seção de Raízes e Tubérculos que também trabalha ram com esta cultivar.

A concentração de $P$ nos órgãos seguiu a mesma ordem que o $\mathrm{N}$. Em todos os órgãos a concentração caiu do início até ofim do ciclo. Estes dados, com pequenas variações, estão de acordo com a maioria dos autores citados.

A época de maior exigência foi ao redor de 140 dias. Assim sendo, sugere-se para efeito de diagnose nutricional as variações obtidas aos 120 dias:

$$
\begin{aligned}
& \text { Folhas: } 0,209 \text { a } 0,228 \\
& \text { Hastes: } 0,165 \text { a } 0,244
\end{aligned}
$$




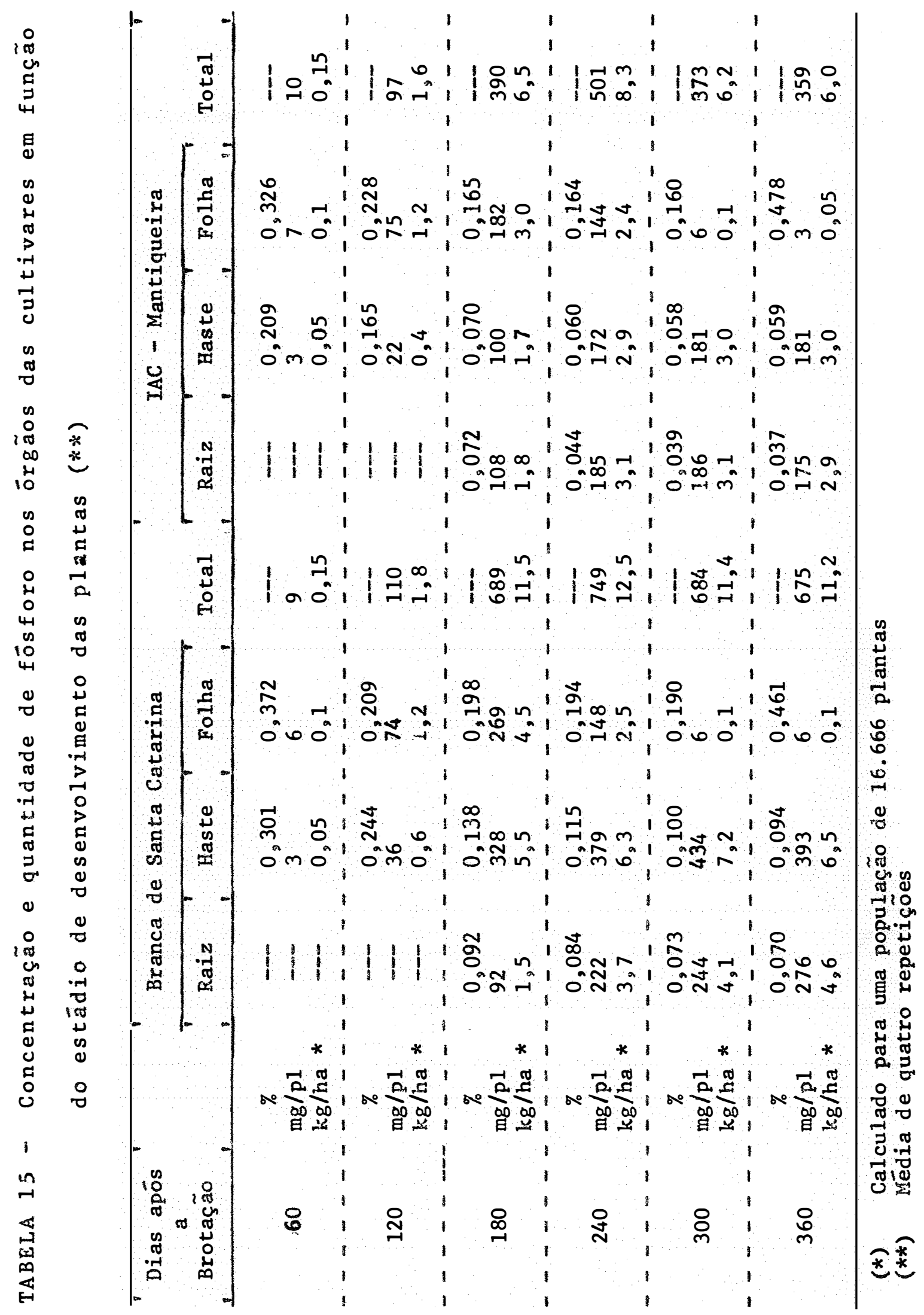




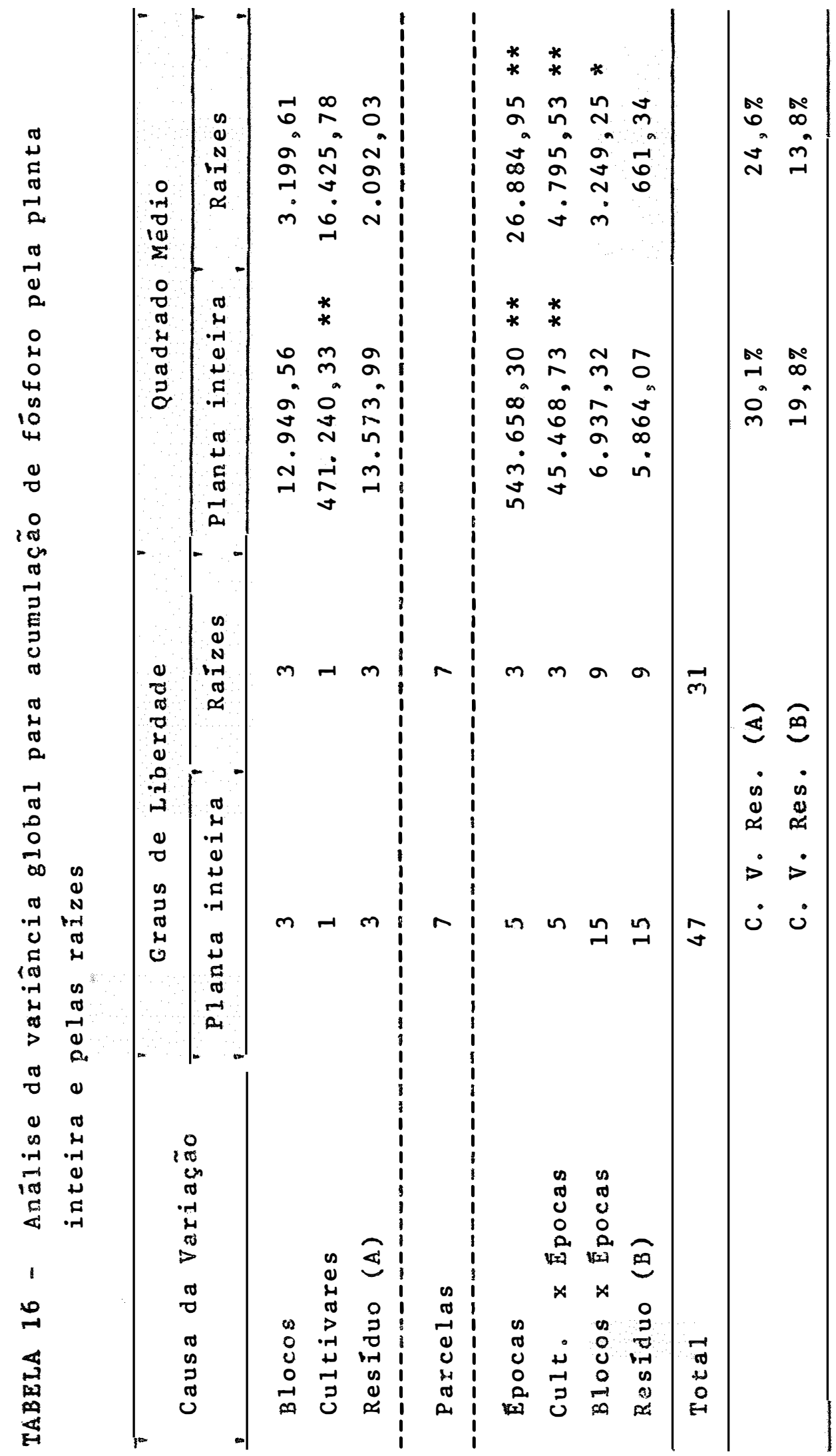




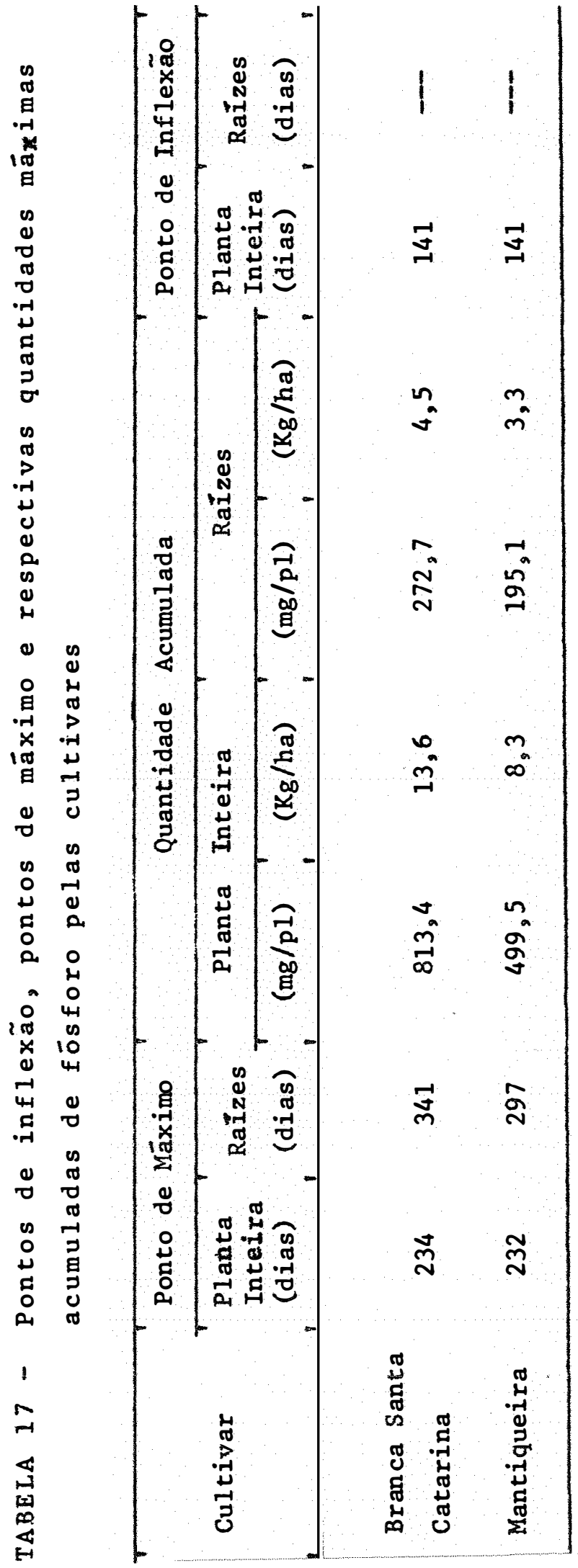


51.

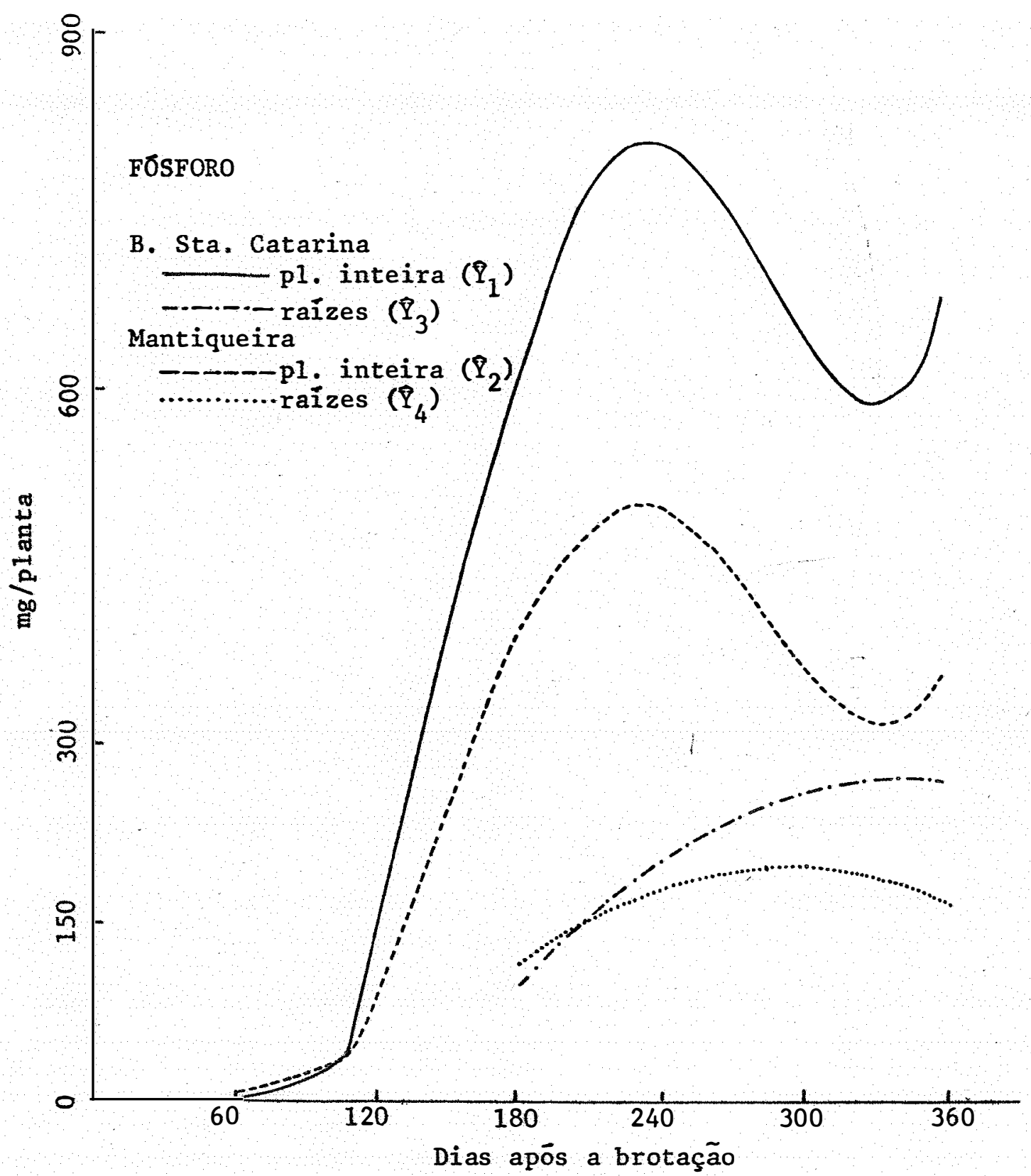

$q_{1}=1.438,3-46,4 x+0,46 x^{2}-1,63 \cdot 10^{-3} x^{3}+0,190 \cdot 10^{-5} x^{4}\left(x^{2}=0,98\right)$

$P_{2}=912,8-29,2 x+0,29 x^{2}-1,03 \cdot 10^{-3} x^{3}+0,119 \cdot 10^{-5} x^{4}\left(r^{2}=0,99\right)$

$\hat{P}_{3}=-514,5+4,62 x-0,0068 x^{2}$

$\left(r^{2}=0,96\right)$

$\mathrm{P}_{4}=-342,7+3,62 \mathrm{x}-0,0061 \mathrm{x}^{2}$

$\left(r^{2}=0,95\right)$

Fig. 3 - Curvas de regressão da quantidade de fósforo ( $\hat{Y}$ ) em função da idade (x), na planta inteira e raízes, das cultivares. 


\section{$5.2 .3-$ Potässio}

Os dados de concentração e quantidade de $\mathrm{K}$ nos ór gãos das cultivares, em diferentes estádios do desenvolvimento das plantas, estão expostos na Tabela 18 .

Na Tabela 19 são apresentados os resultados da análi se da variância global para $K$ na planta inteira e raízes.

No caso das raízes, as cultivares comportaram-se igualmente face às épocas estudadas, todavia, ofizeram em quan tidades diferentes, cabendo à Mantiqueira uma acumulação maior.

Quando se considerou a planta inteira, as cultivares tiveram o mesmo comportamento em relação às épocas de acumulação e não diferiram no total de $K$ acumulado, provavelmente, pe la maior quantidade de $K$ na parte aérea (hastes + folhas) da cultivar Branca de Santa Catarina.

Ambas as cultivares foram representadas por equações de regressão de 49 grau para a planta inteira e de 19 grau para as raízes, como está exposto na Figura 4 . 0s pontos de má ximo e de inflexão, para a planta inteira, obtidos através das equações ajustadas, acham-se na Tabela 20. Para as equações de 10 grau considerou-se a última época de amostragem como pon to de máximo.

De acordo com a literatura consultada nota-se que o $\mathrm{K}$, em média, é o elemento mais absorvido pela mandioca (Tabe 1a 3). 
Pelos dados apresentados a acumulação foi maior para - N seguido pelo $K$, o que, apesar de não concordar coma maio ria dos autores, está de acordo com OELSLIGLE (1975); DUFOURNET e GOARIN (1957) e BONNEFOY (1933).

No Estado de São Paulo, a mandioca raramente tem res pondido à adubação potássica (INSTITUTo AGRONôMICo, 1973-1973). Em ensaio de areia lavada, MALAvolta et ali $i$ (1953) admitem o efeito favorāvel da dose dupla de $N$, combinada às doses simples de $P$ e $K$.

No inicio do desenvolvimento o teor de K foi maior nas hastes que nas folhas e raízes. Apös os 60 dias, embora decrescente para todos os órgãos até o final do ciclo, a ordem foi a seguinte: folhas, hastes e raízes.

Para a diagnose nutricional, sugere-se a variação nos teores aos 120 dias, por estar mais próximo do período de mäxima absorção:

$$
\begin{array}{ll}
\text { Folhas: } & 1,80 \text { a } 2,23 \\
\text { Hastes: } & 1,50 \text { a } 1,67
\end{array}
$$




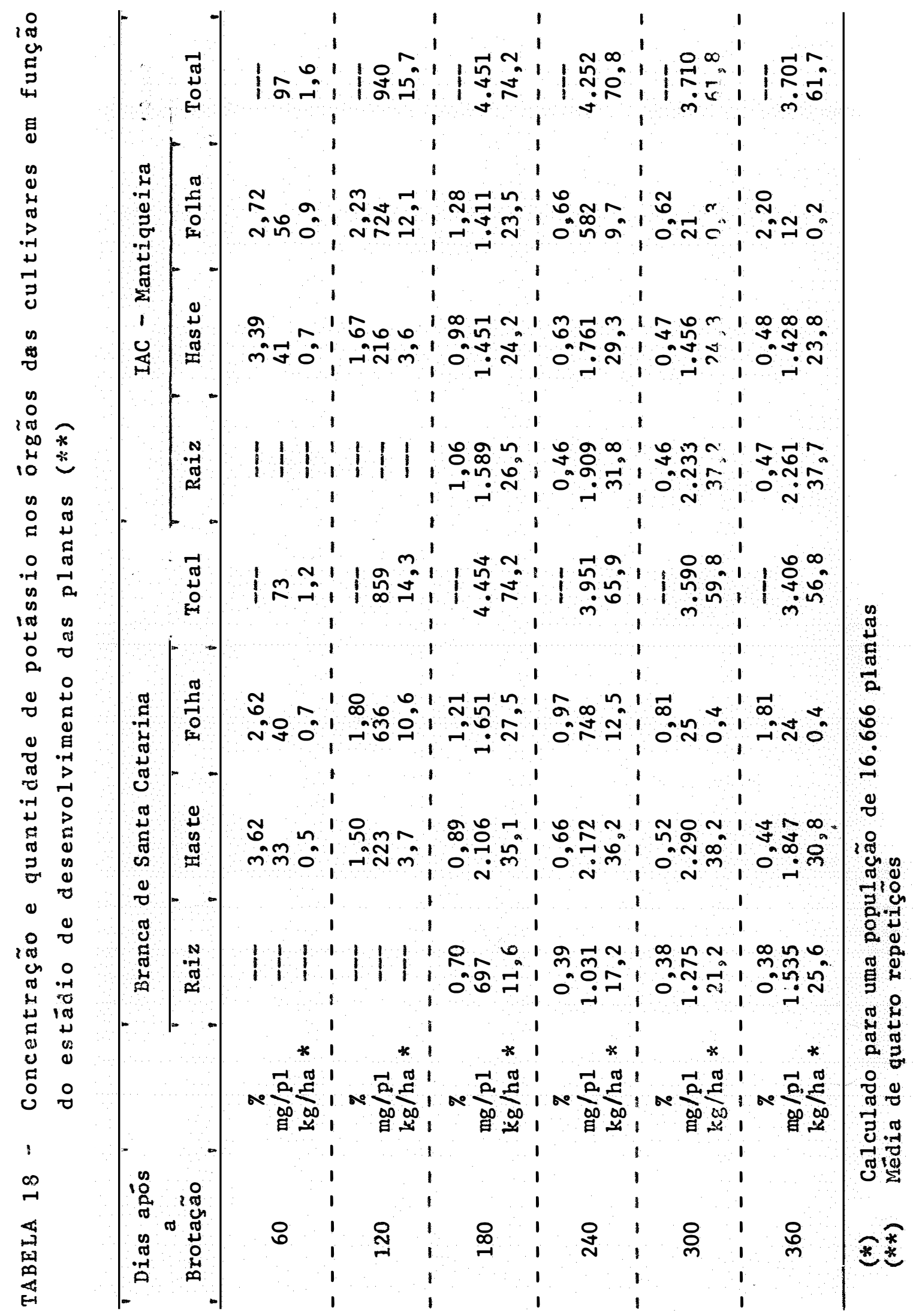




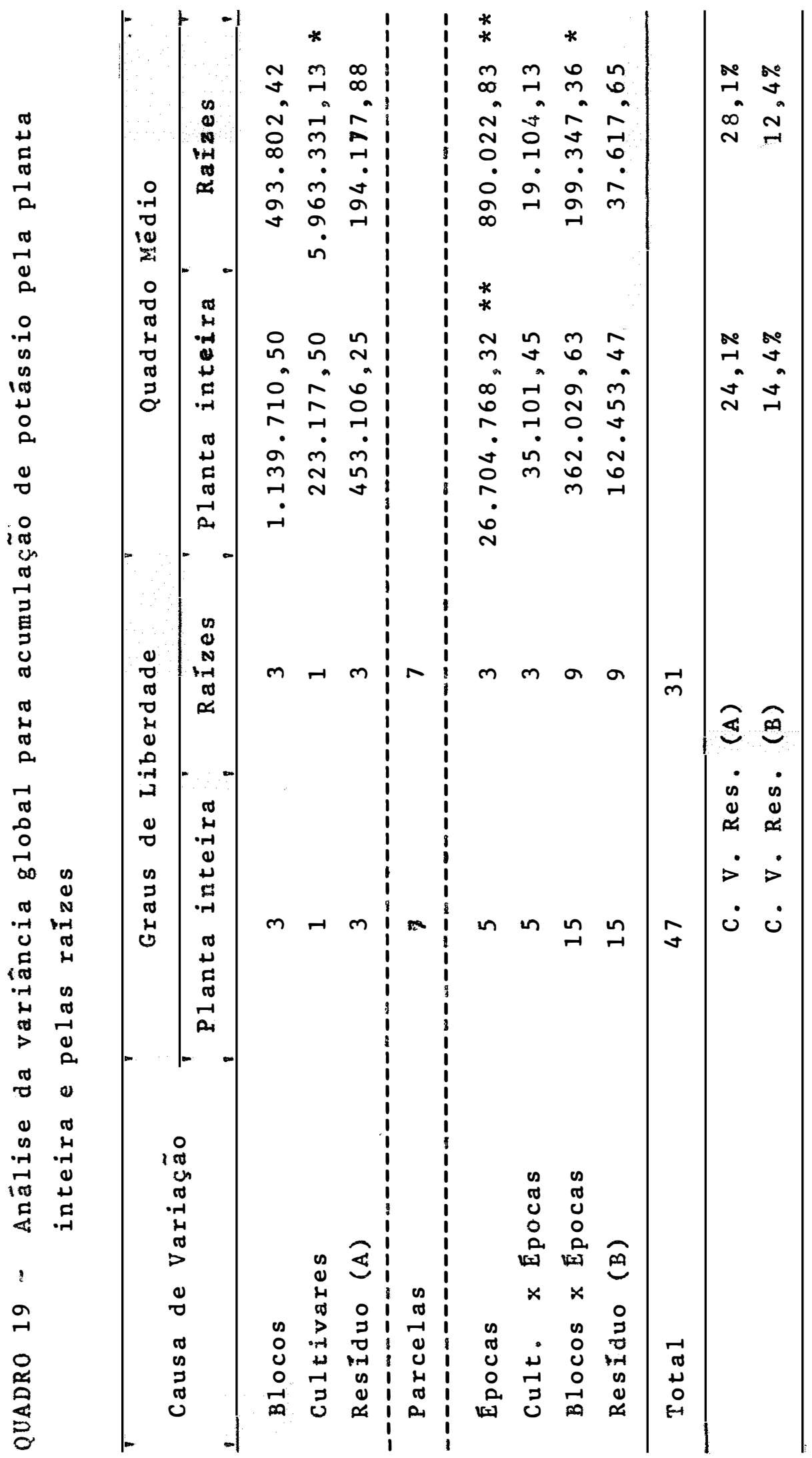




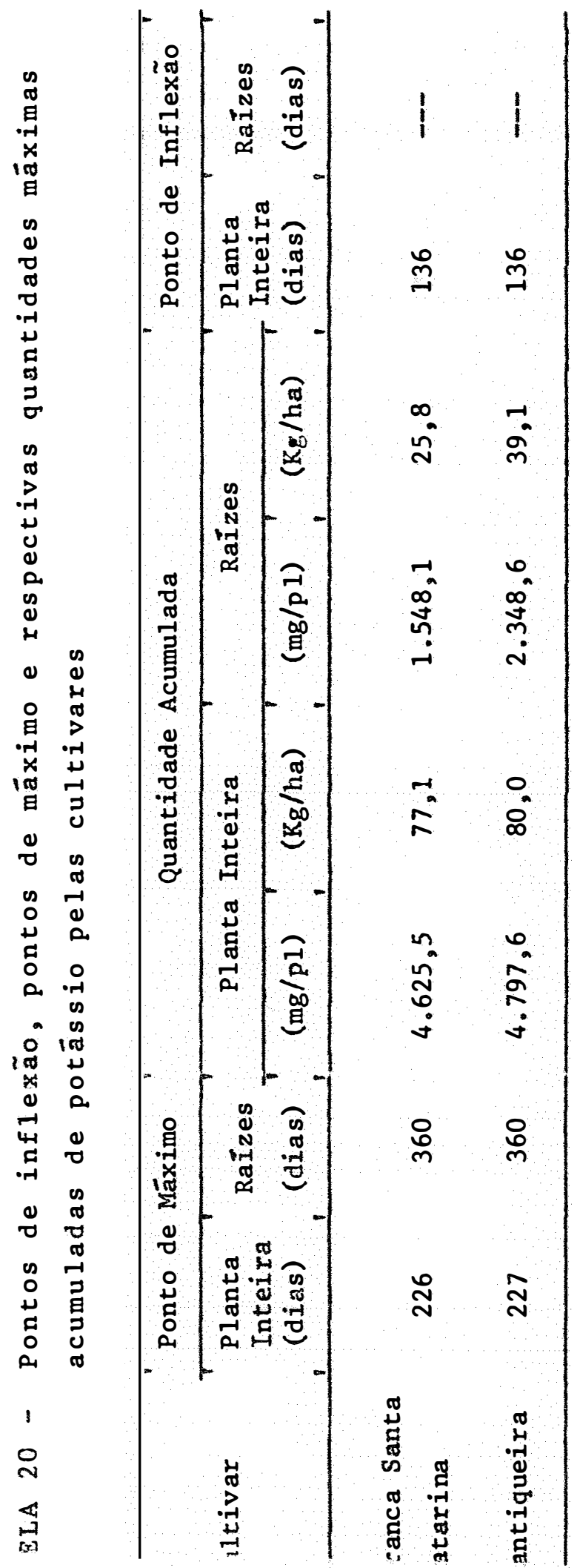




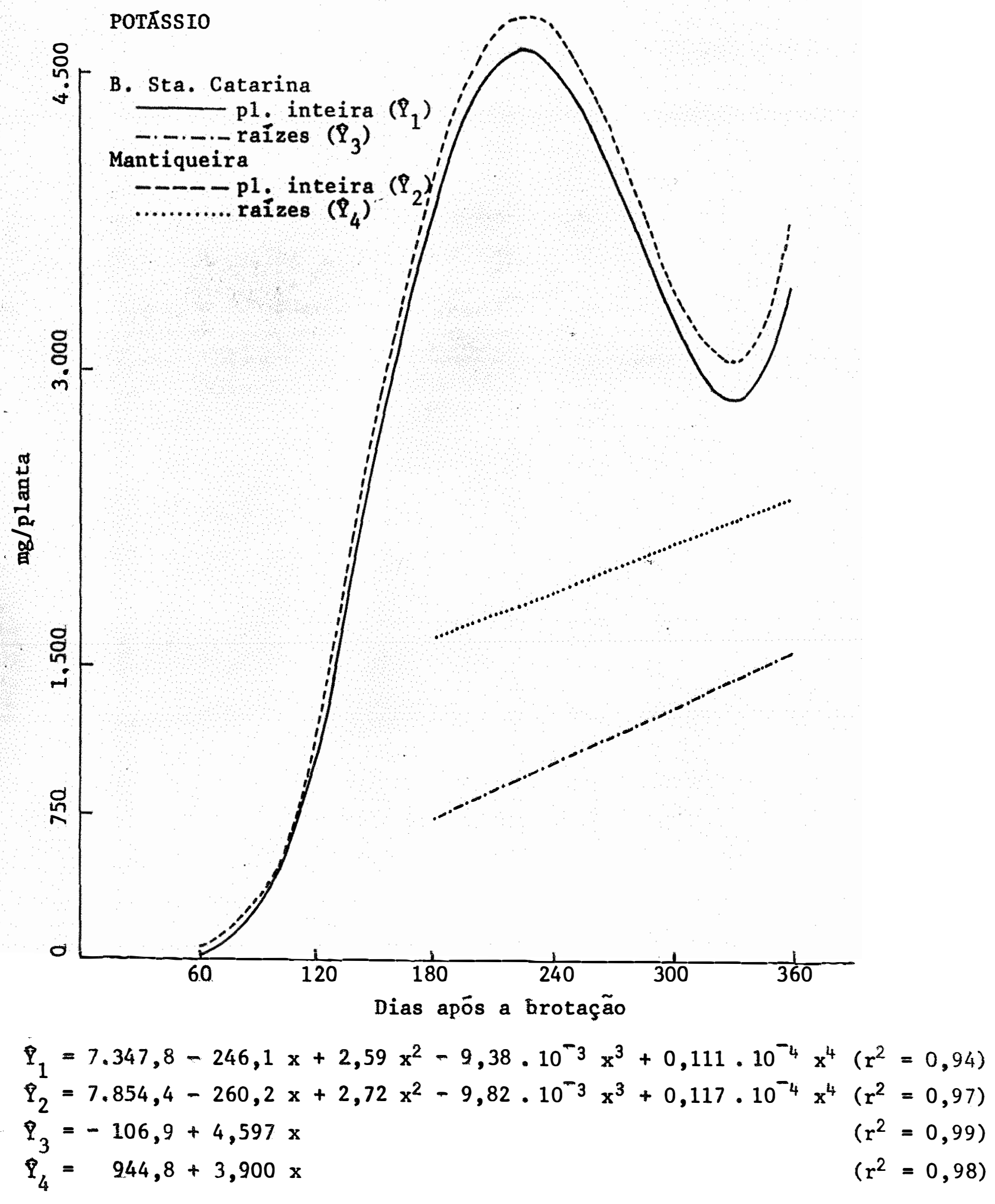

Fig. 4 - Curvas de regressão da quantidade de potássio ( $($ ) em função da idade $(x)$, na planta inteira e raízes, das cultivares 


\section{2 .4 - Cálcio}

Na Tabela 21 são apresentados os dados referentes à concentração e quantidade de cálcio, nos órgãos das cultivares em função do crescimento.

A análise da variância para a quantidade de cālcio na planta inteira e nas raízes, abrangendo as épocas estudadas constam da Tabela 22 .

Embora as cultivares não diferiram na quantidade total acumulada, quer pela planta inteira ou somente pelas raízes, nos dois casos a interação cultivar x época foi significativa evidenciando comportamento diferencial das mesmas em relação às épocas de acumulação.

A evolução da quantidade de cálcio na planta inteira e raízes puderam ser explicadas por equações de 40 e 20 graus, respectivamente. As curvas e equações correspondentes encon tram-se na Figura 5 .

A cultivar Mantiqueira atingiu o máximo da acumula ção de cálcio nas raizes aos 300 dias e a Branca de Santa Cata rina, aos 360 dias, acompanhando, praticamente, suas respectivas curvas de acumulação de matéria seca. Para a planta intei ra, a época de maior exigência foi aos 141 dias para as duas cultivares que atingiram o máximo ao redor dos 233 dias. Estes dados e respectivas quantidades acumuladas acham-se na Tabe1a 23 . 
A tolerância da mandioca à acidez do solo é citada com frequência na literatura. 0 efeito benéfico da calagem, normalmente, é atribuído ao fornecimento de cálcio e magnésio do que propriamente a elevação do pH ou a neutralização do alu mínio (HOWELER, 1975).

Por essa razão e, em virtude das quantidades razoáveis de cálcio existentes nos solos, raramente tem-se consegui do efeito positivo da calagem.

HOWELER (1975) trabalhando em oxissolos da Colômbia, parecidos com os solos de cerrado do Brasil, conseguiu resposta à calagem (relação $C a: M g$ de $10: 1$ ) na dose mäxima de 0,5 t/ha. Além dessa dose o rendimento caiu. Segundo o autor, es sa queda pode ser devida a diminuição na absorção de $K, Z_{n}$, $\mathrm{Cu}$ e Mn, elementos estes, que a mandioca parece exigir mais que os outros cultivos ou não tem a mesma capacidade para extraí-1os.

No Estado de São Paulo, a mandioca não tem respondido satisfatoriamente à calagem, mesmo em solos pobres e ācidos. Pelos resultados apresentados verifica-se que a quan tidade de cālcio absorvida é alta, vindo logo após o potásio, sendo necessário mais estudos para que a questão seja melhor esclarecida.

os teores nas folhas, hastes e raízes estäo contidos nos intervalos obtidos da literatura e apresentados na Tabe 1a 3. o aumento no teor de cálcio nas folhas a partir dos 
240 dias está de acordo com cours et alii (1953) e NIJHOLT (1935).

Os órgãos que mais concentraram cálcio foram pela or dem: folkas. hastes e raízes. Com fins de diagnose nutricional, as variações nos teores, aos 120 dias foram:

$$
\begin{array}{ll}
\text { Folhas: } & 1,15-1,41 \\
\text { Hastes: } & 0,82-0,96
\end{array}
$$




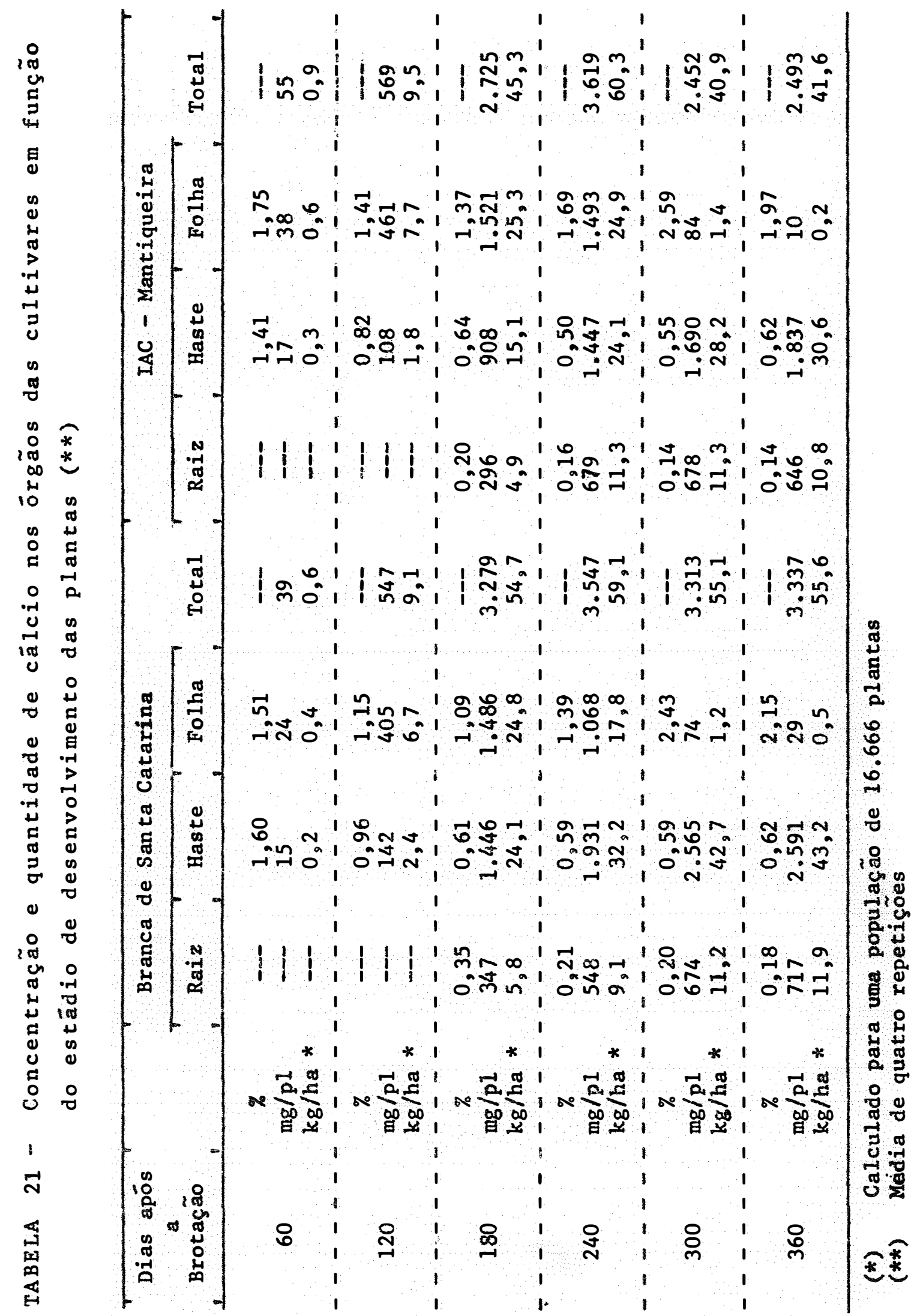




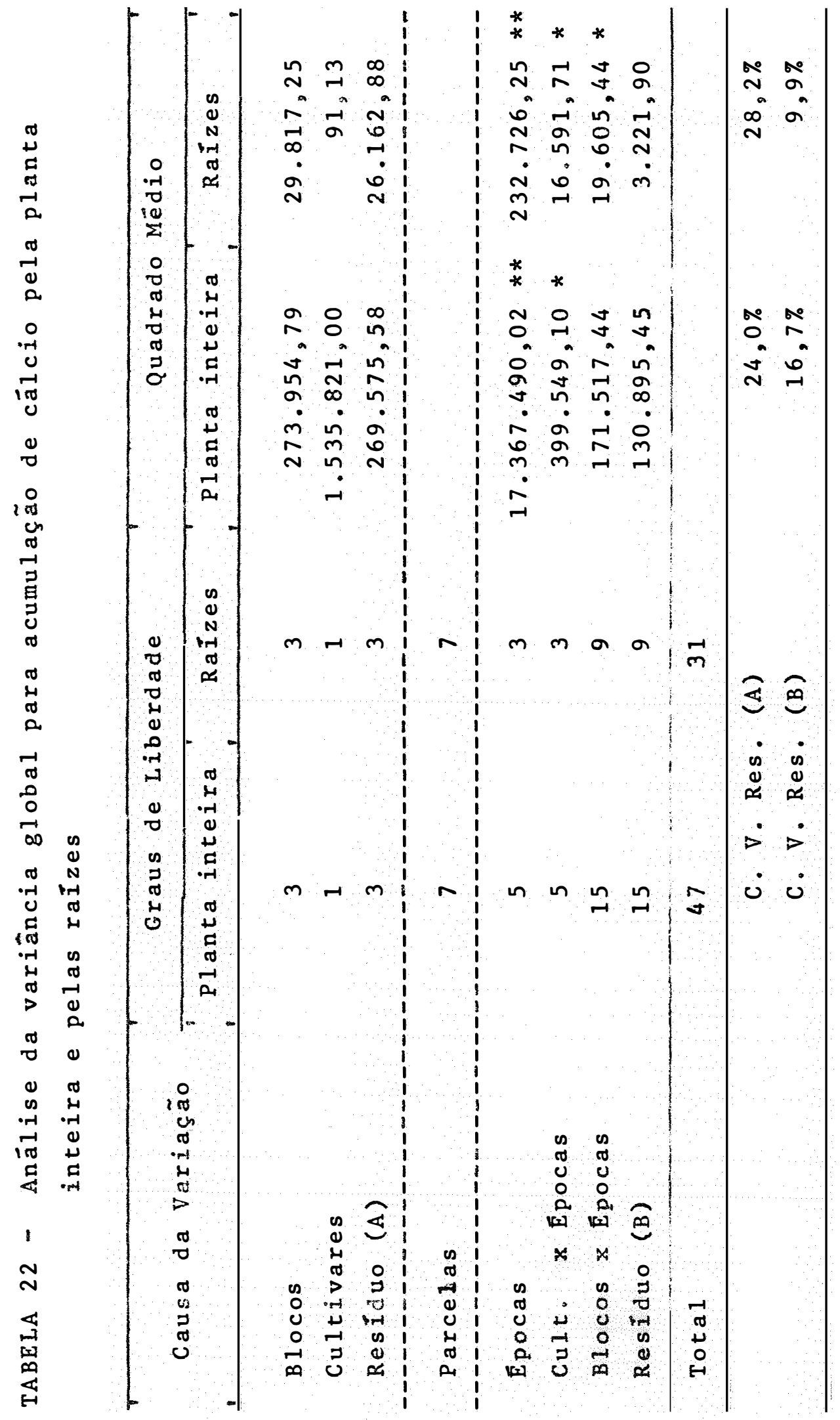




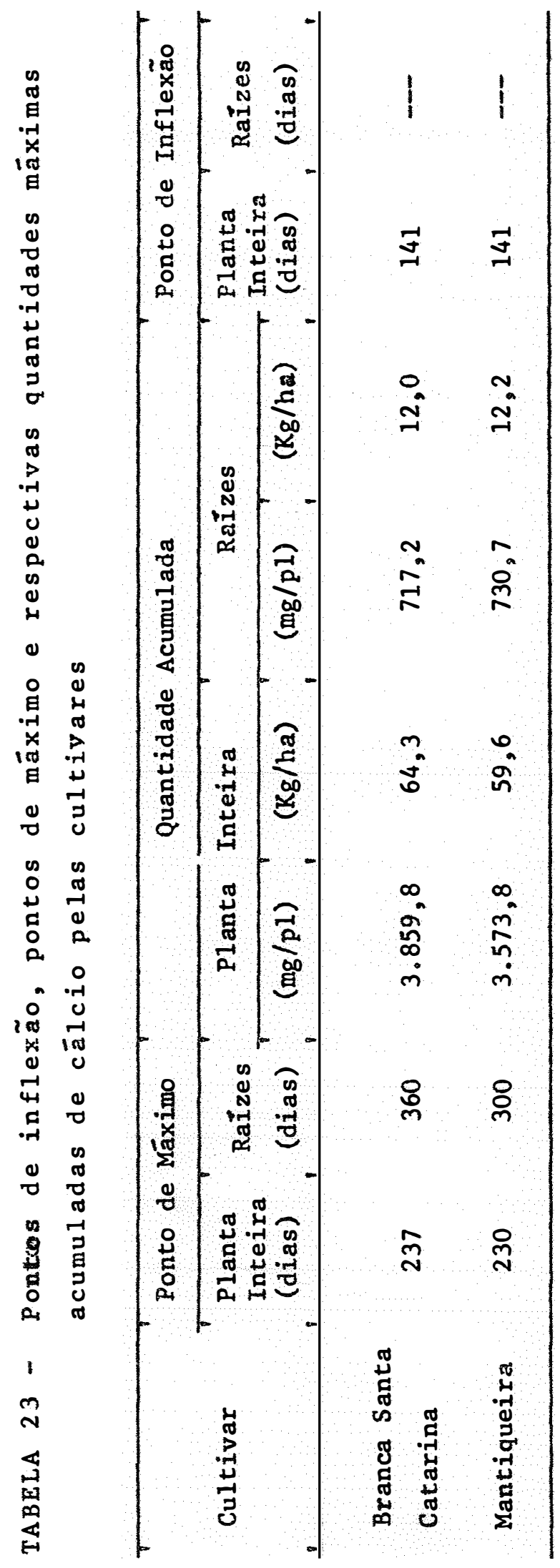




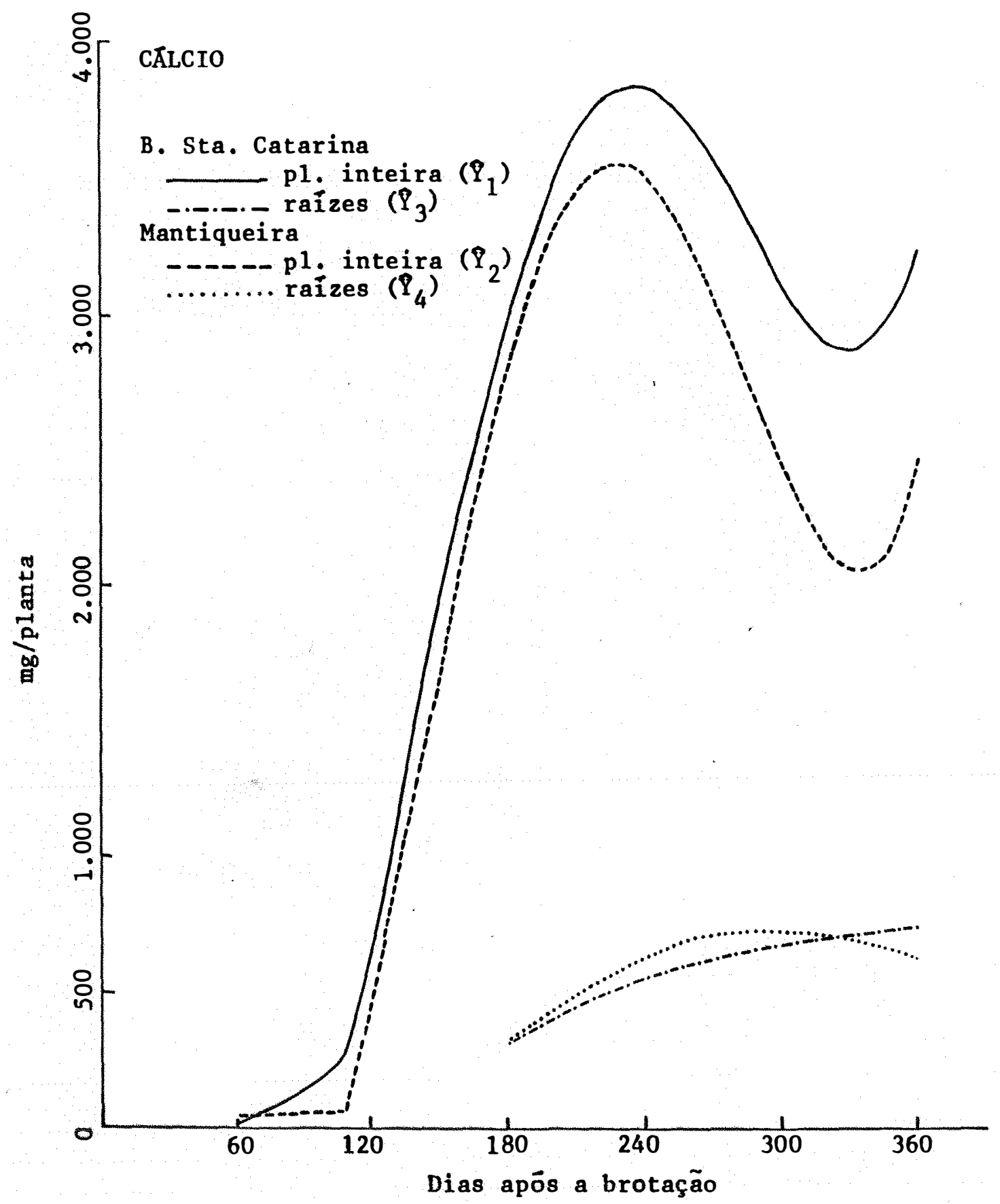

$\begin{array}{ll}Q_{1}=6.544,6-212,0 x+2,14 x^{2}-7,52 \cdot 10^{-3} x^{3}+0,875 \cdot 10^{-5} x^{4}\left(r^{2}=0,98\right) \\ Q_{2}=7.828,5-246,6 x+2,43 x^{2}-8,53 \cdot 10^{-3} x^{3}+0,993 \cdot 10^{-5} x^{4} & \left(r^{2}=0,99\right) \\ Q_{3}=-737,3+8,00 x-0,011 x^{2} & \left(r^{2}=0,99\right) \\ P_{4}=-1.869,1+17,32 x-0,029 x^{2} & \left(r^{2}=0,94\right)\end{array}$

Fig. 5 - Curvas de regressão da quantidade de cālcio (Y) em função da idade $(x)$, na planta inteira e raízes, das cultivares. 


\section{2 .5 - Magnésio}

Os dados obtidos para concentração e quantidade de magnésio nos órgãos das cultivares nas diferentes fases do crescimento das plantas, acham-se na Tabela 24.

Pelos resultados obtidos da anālise da variância (Ta bela 25), verifica-se que as cultivares tiveram o mesmo compor tamento quanto às épocas estudadas e também não diferiram na quantidade absoluta acumulada pelas raízes e pela planta intei ra.

A acumulação de magnésio nas raízes seguiu a tendência da curva de matéria seca. A cultivar Mantiqueira acumulou cerca de $50 \mathrm{mg} / \mathrm{p} 1$ anta mais que a outra, todavia, esta diferença não foi significativa, talvez, pelos mesmos motivos já ex postos. A representação gräfica das curvas, bem como as equações correspondentes para a planta inteira e raízes encontramse na Figura 6 e os pontos de máximo e de inflexão, na Tabela 26

Os estudos sobre efeito da adubação magnesiana em man dioca são escassos. HOWELER (1978) relata resultados obtidos por NGONGI (1976), de deficiência de magnésio em 0xissolos, U1 tissolos e solos de cinzas vulcânicas da Colómbia e resposta té $50 \mathrm{~kg} / \mathrm{ha}$ de $\mathrm{Mg}$. Além dessa dose a produção diminuiu pela deficiência induzida de cálcio.

Dos elementos estudados, o magnésio foi o elemento cuja concentração, nos órgãos, menos variou desde o início do 
crescimento até a senescência das plantas. As concentrações encontradas estão de acordo com as da literatura e, pela ordem, os örgãos que apresentaram maior concentração foram: fo lhas, hastes e raízes.

0 ponto de inflexão da curva ocorreu cerca de 145 dias após a brotação, por este motivo e para efeito de diagno se nutricional, são apresentadas as variações nos teores aos 120 dias:

$$
\begin{array}{ll}
\text { Folhas: } & 0,28-0,31 \\
\text { Hastes: } & 0,24-0,29
\end{array}
$$




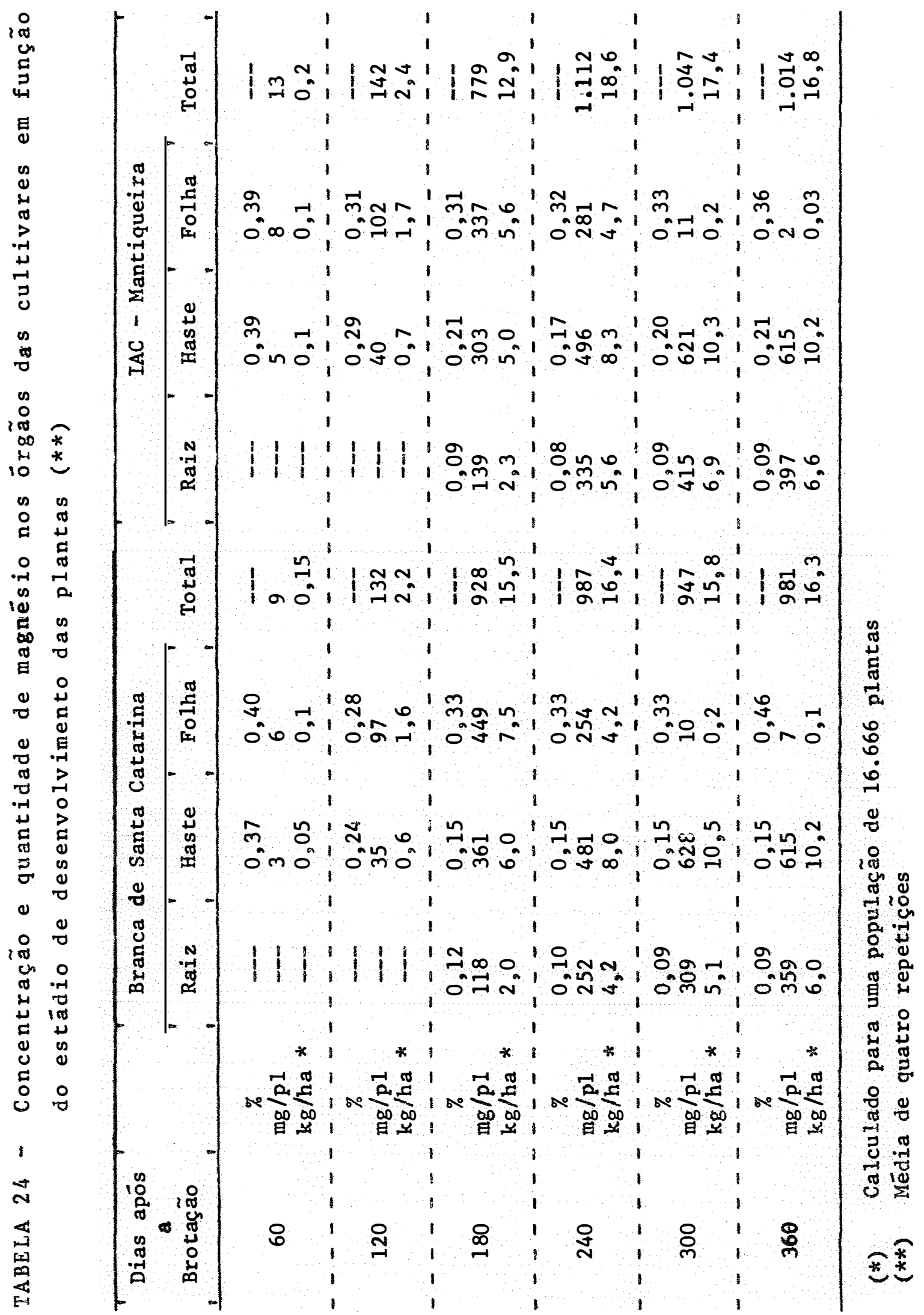


68.

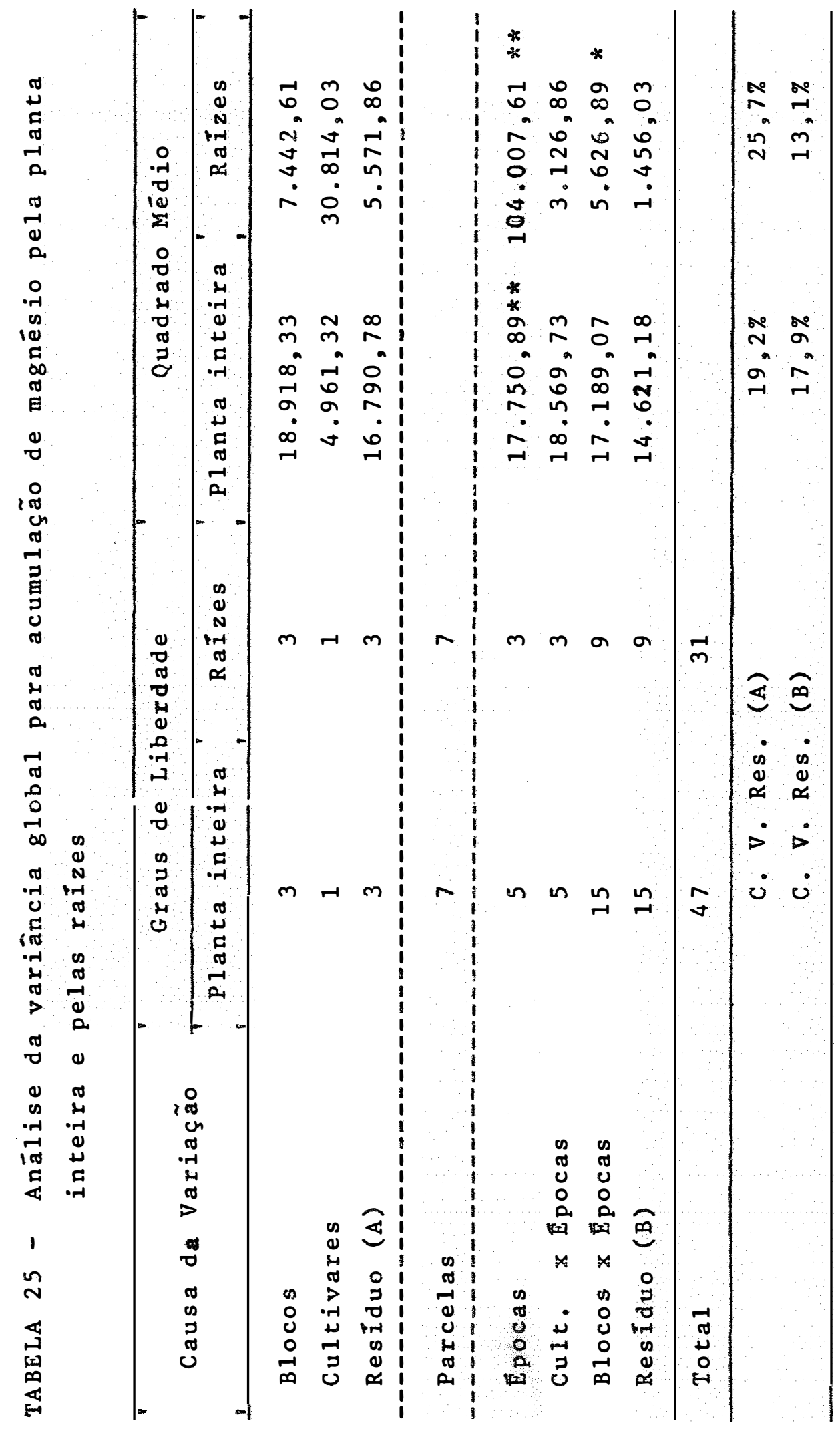




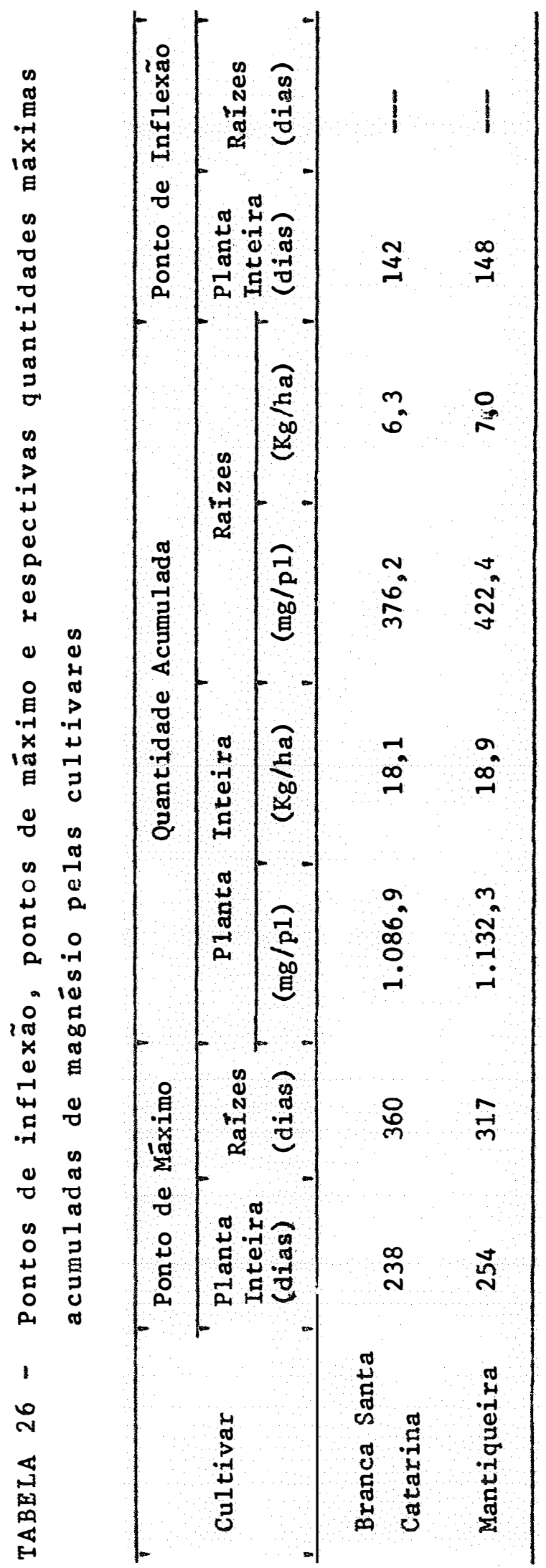




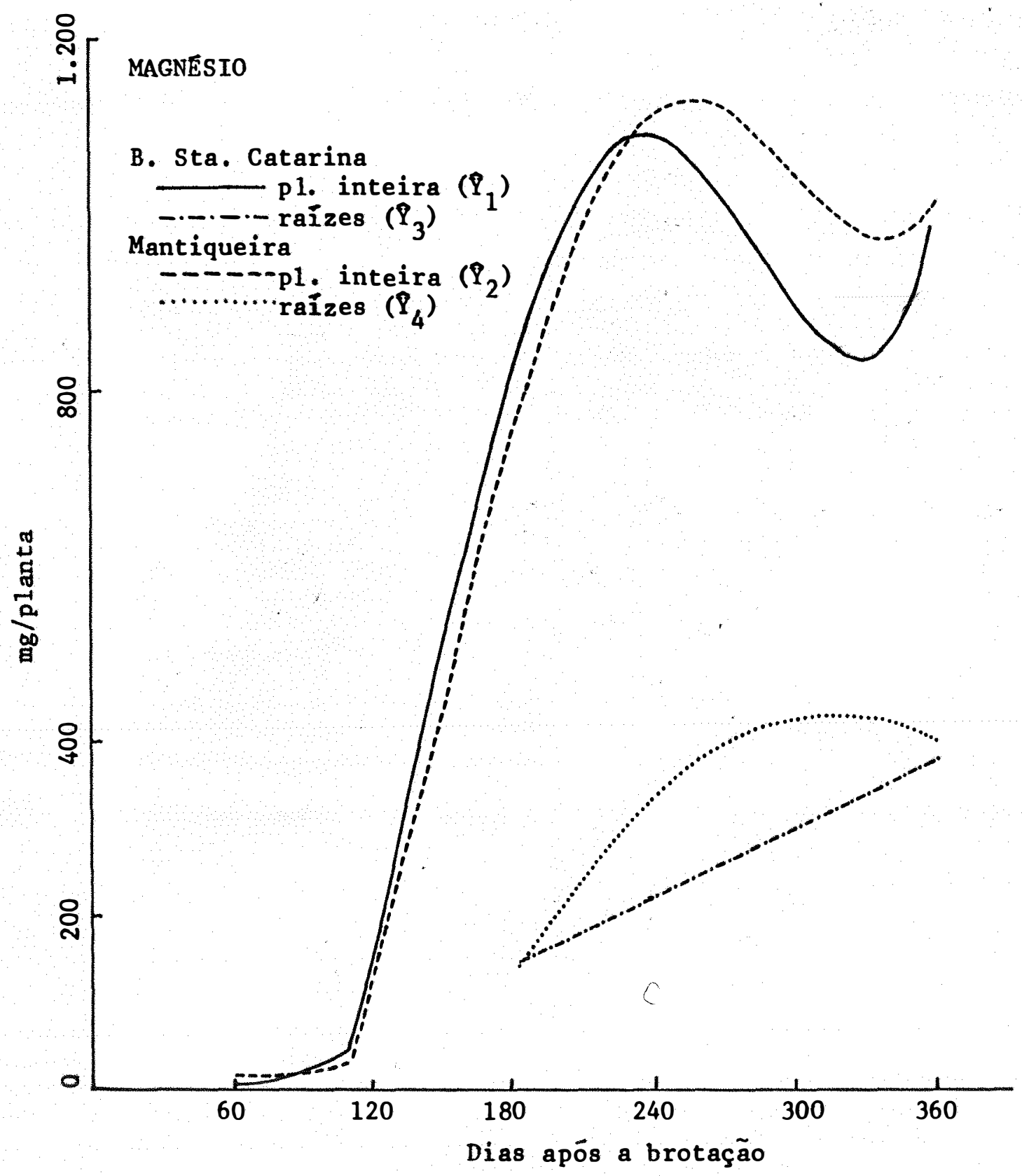

$$
\begin{array}{ll}
P_{1}=1.925,3-62,1 x+0,62 x^{2}-2,18 \cdot 10^{-3} x^{3}+0,255 \cdot 10^{-5} x^{4} & \left(r^{2}=0,98\right) \\
P_{2}=1.766,5-55,3 x+0,53 x^{2}-1,80 \cdot 10^{-3} x^{3}+0,200 \cdot 10^{-5} x^{4} & \left(r^{2}=0,99\right) \\
Q_{3}=-91,3+1,299 x & \left(r^{2}=0,94\right) \\
Q_{4}=-1.083,7+9,48 x-0,015 x^{2} & \left(r^{2}=0,99\right)
\end{array}
$$

Fig. 6 - Curvas de regressão da quantidade de magnésio $(\uparrow)$ em função da idade (x), na planta inteira e raízes, das cultivares. 


\section{$5.2 .6-$ Enxofre}

Na Tabela $27^{\sim}$ sao apresentados os dados obtidos refe-rentes à concentração e quantidade de $S$, nos órgãos das cultivares, em função da idade das plantas.

Pela anālise da variância (Tabela 28), observa-se que houve diferença significativa na acumulação de enxofre pelas raizes e, para a planta inteira, o valor de F calculado es tá muito próximo ao limite de significância.

A acumulação de enxofre nas raizes foi maior para a cultivar Mantiqueira e menor quando se considerou a planta inteira. Esta inversão, provavelmente, é devida a partição dife rencial da matéria seca das cultivares, uma vez que a concen tração de enxofre nos órgãos foi semelhante para ambas.

As curvas de regressão ajustadas, para as duas culti vares, recaíram sobre equações de 49 e 39 graus, para a planta inteira e raizes, respectivamente (Figura 7). 0s pontos de máximo e de inflexão destas equações são apresentados na Tabe1 a 29 .

0 enxofre tem sido muito pouco estudado em mandioca. NGONGI (1976), citado por HOWELER (1978), encontrou nas planicies orientais da Colómbia, resposta positiva ao sulfato de po tássio em relação ao cloreto de potássio e obteve efeito similar misturando enxofre com ácido clorídico. 0 autor concluiu que o enxofre era fator limitante e que aplicaçóes altas de cloretos podiam inibir a absorção de sulfato e induzir defici- 
ência.

Pelos dados apresentados verifica-se que apenas $20 \%$ aproximadamente do total do enxofre e cálcio acumulado estão nas raizes, evidenciando menor exportação relativa desses nutrientes.

$$
\text { os resultados analiticos mostraram que as folhas e }
$$
hastes possuem maior concentração de enxofre que as raízes. Nas folhas, os teores caíram continuamente em função da idade e nas hastes e raízes o decréscimo foi descontínuo.

0 ponto de einflexão para acumulação total de enxo fre esteve em torno de 140 dias, assim, para efeito de diagnose nutricional, sugeremsse as variações nos teores encontrados aos 120 dias:

$$
\begin{aligned}
& \text { Folhas: } 0,208-0,231 \\
& \text { Hastes: } 0,283-0,291
\end{aligned}
$$




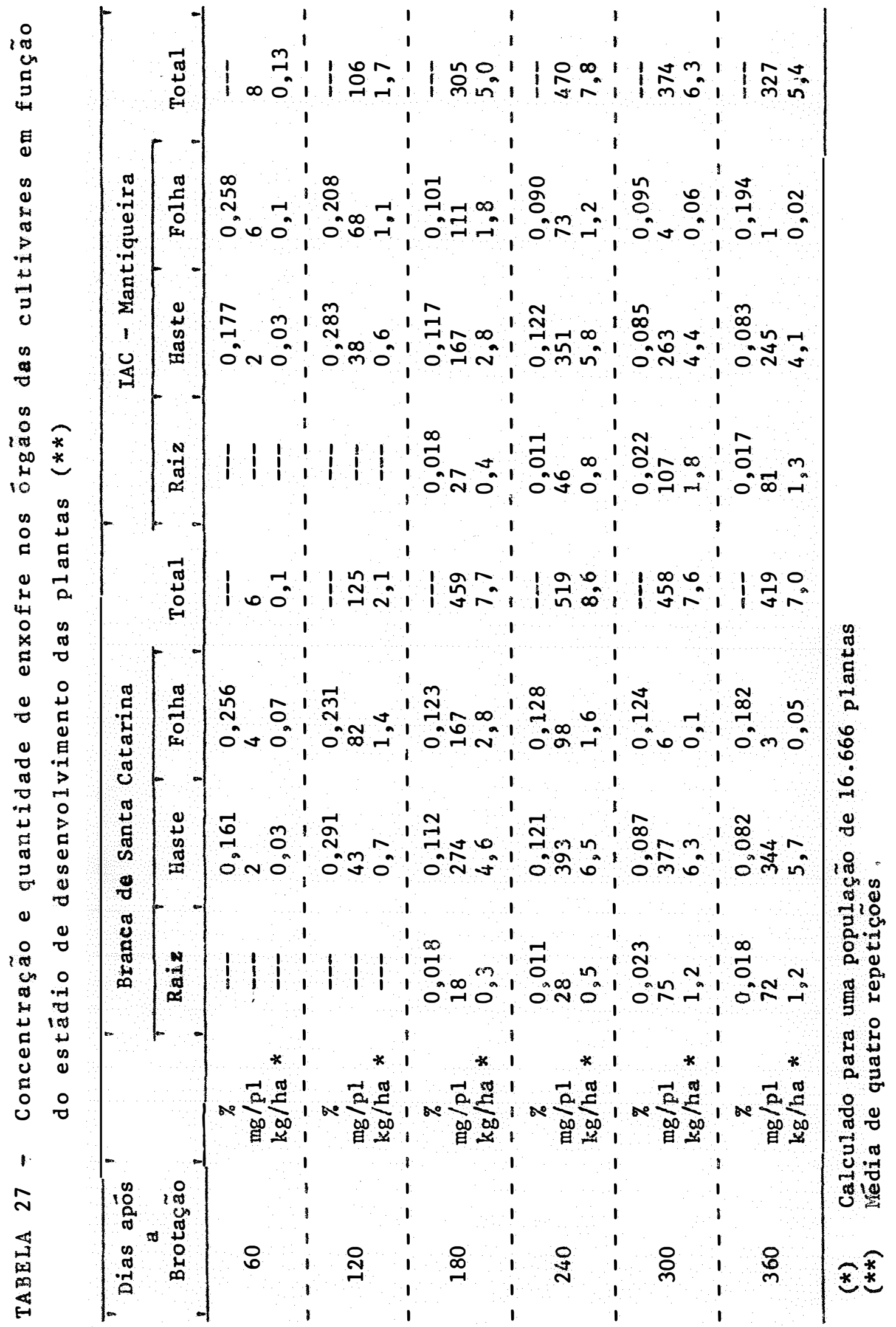


74.

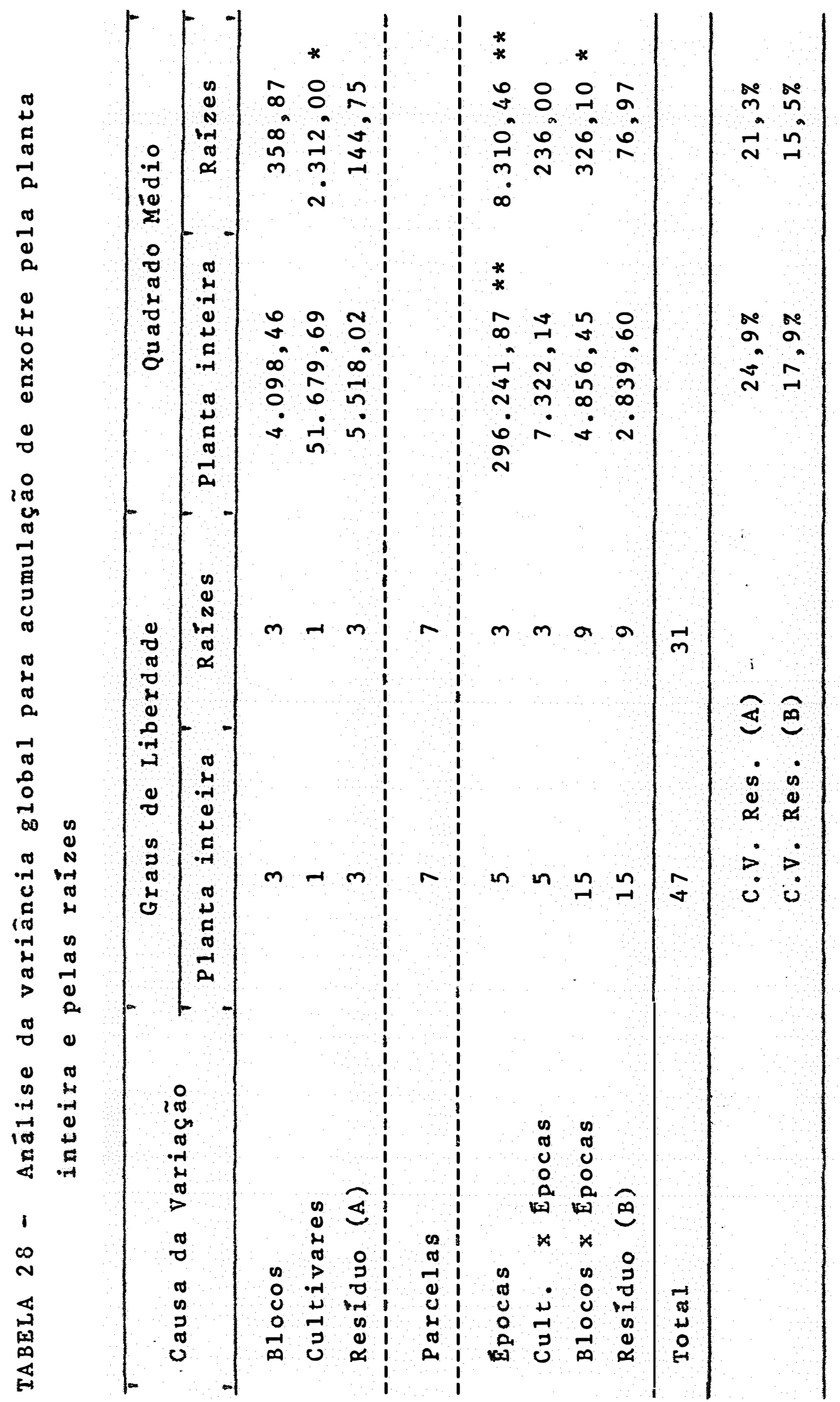




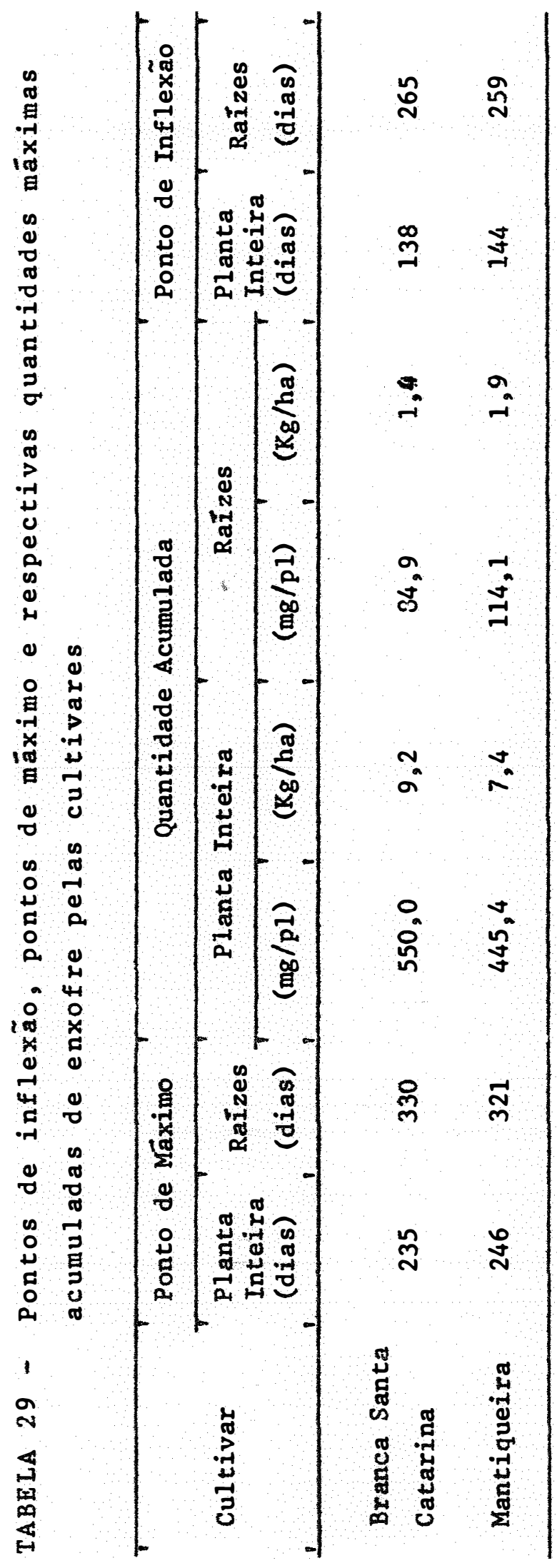




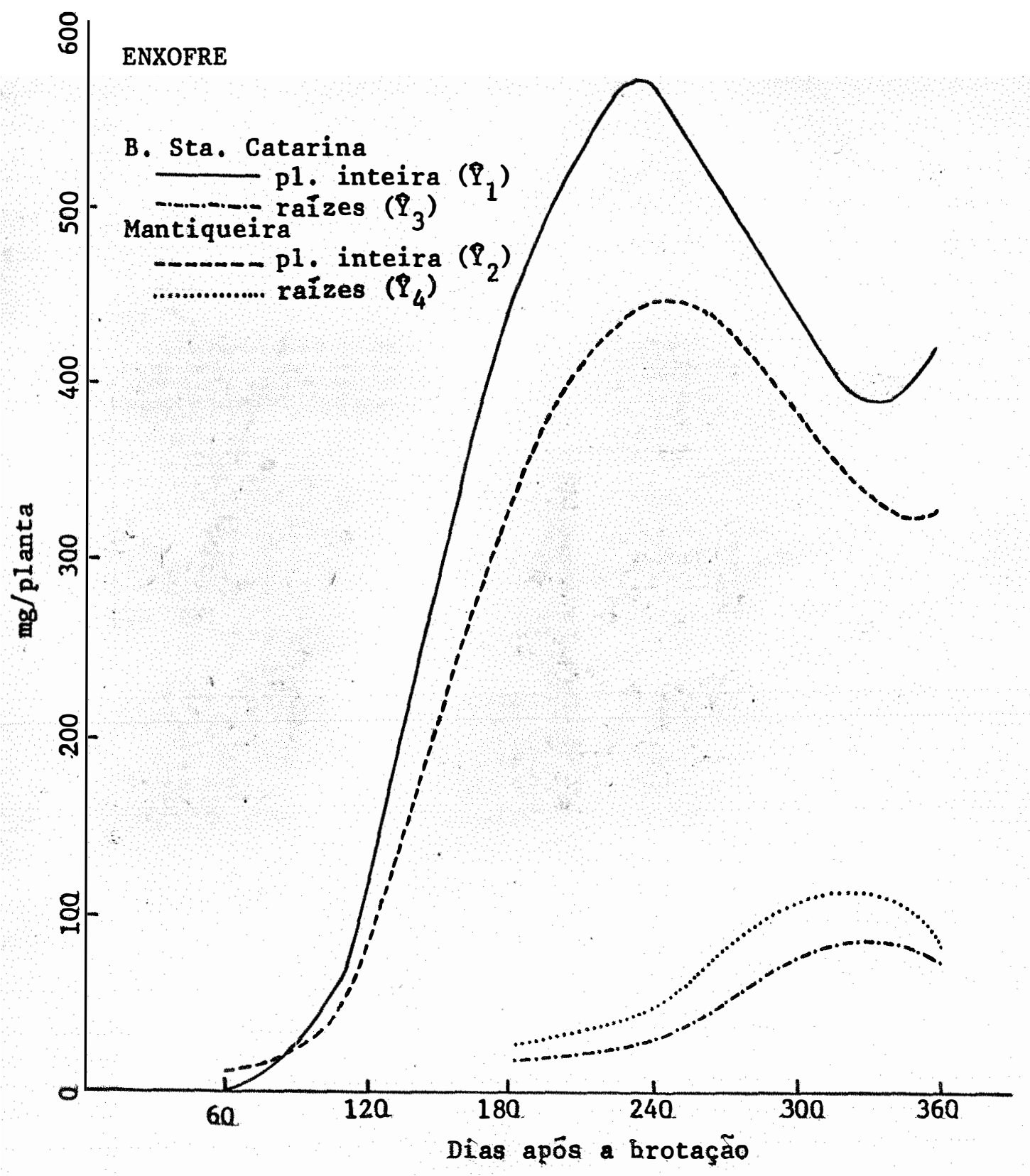

$P_{1}=754,1-25,2 x+0,26 x^{2}-0,93 \cdot 10^{-3} x^{3}+0,108 \cdot 10^{-5} x^{4}\left(x^{2}=0,99\right)$

$P_{2}=574,6-18,5 x+0,19 x^{2}-0,64 \cdot 10^{-3} x^{3}+0,071 \cdot 10^{-5} x^{4}\left(x^{2}=0,99\right)$

$\hat{P}_{3}=1.082,2-13,4 x+0,05 x^{2}-0,67 \cdot 10^{-4} x^{3} \quad\left(r^{2}=0,99\right)$

$\hat{q}_{4}=1.514,3-19,0 x+0,08 x^{2}-1,00 \cdot 10^{-4} x^{3} \quad\left(x^{2}=0,99\right)$

Fig. 7 - Curvas de regressão da quantidade de enxofre $(\hat{Y})$ en função da idade $(x)$, na planta intei ra e raízes, das cultivares. 


\section{3 - Produção de Raĩzes Frescas}

As cultivares diferiram na produção de raízes fres cas tal como aconteceu para a matéria seca. As produções observacias e as calculadas, através das equações de regressão, são apresentadas na Tabela 30 .

0 ponto de máximo e a respectiva quantidade máxima de raizes frescas, estimadas a partir das equações de regres são, são apresentadas a seguir:

\begin{tabular}{lccc} 
Cultivar & $\begin{array}{c}\text { Ponto de Máximo } \\
\text { (dias) }\end{array}$ & $\begin{array}{c}\text { Quantidade Mäxima } \\
\text { B }\end{array}$ & $\mathrm{kg} / \mathrm{pl}$ \\
Branca de Santa & 360 & 971,7 & 16.194 \\
Catarina & 311 & $1.290,6$ & 21.509 \\
\hline
\end{tabular}

A estimativa da produção de raízes, procedida desta maneira, parece representar melhor o fenômeno da produção, em relação a uma só amostragem final, principalmente, em virtude das cultivares não terem apresentado o mesmo ciclo de matura:ção.

os resultados obtidos estão de acordo,dentro de certos limites, com PEREIRA et alii (1977) que encontraram 19,5 e $20,0 \mathrm{t} / \mathrm{ha}$, respectivamente, para as cultivares Branca de San 
ta Catarina e Mantiqueira, como mẻdia de 9 (nove) ensaios de 1 (um) ciclo vegetativo, em diferentes localidades do Estado de São Paulo.

TABELA 30 - Produção observada e calculada de raízes frescas em diferentes estádios de desenvolvimento das plantas

\begin{tabular}{|c|c|c|c|c|c|c|}
\hline \multirow{2}{*}{ Cultivar } & & & \multicolumn{4}{|c|}{ Dias apōs a Brotação } \\
\hline & & & 180 & 240 & 300 & 360 \\
\hline \multirow[b]{2}{*}{$\begin{array}{c}\text { Branca de } \\
\text { Sant a }\end{array}$} & \multirow{2}{*}{ Observada } & $\mathrm{g} / \mathrm{p} 1$ & 414,5 & 774,2 & 844,2 & 990,0 \\
\hline & & $\mathrm{kg} / \mathrm{ha}$ * & 6.908 & 12.903 & 14.069 & 16.611 \\
\hline \multirow[t]{2}{*}{ Catarina } & \multirow{2}{*}{ Calculada } & (I) $g / p 1$ & 432,8 & 719,4 & 899,0 & 971,7 \\
\hline & & $\mathrm{kg} / \mathrm{ha}$ * & 7.213 & 11.990 & 14.983 & 16.194 \\
\hline \multirow{4}{*}{$\begin{array}{l}\text { Mantiquei- } \\
\text { ra }\end{array}$} & \multirow{2}{*}{ Observada } & $g / p 1$ & 590,8 & 1125,4 & 1250,4 & 1204,2 \\
\hline & & $\mathrm{kg} / \mathrm{ha}$ * & 9.846 & 18.756 & 20.839 & 20.069 \\
\hline & \multirow{2}{*}{ Calculada } & (2) $\mathrm{g} / \mathrm{pl}$ & 602,7 & 1089,5 & 1286,0 & 1192,2 \\
\hline & & $\mathrm{kg} / \mathrm{ha}$ * & 10.045 & 18.158 & 21.432 & 19.869 \\
\hline
\end{tabular}

(*) Calculado para uma população de 16.666 plantas

$$
\begin{aligned}
& \hat{Y}=-1.068,5+11,01 x-0,01485 x^{2}\left(r^{2}=0,96\right) \\
& \hat{Y}=-2.599,5+25,05 x-0,04032 x^{2}\left(r^{2}=0,99\right)
\end{aligned}
$$


5.4 - Extração e Exportação de Nutrientes.

A extração (planta inteira) e exportação (raízes) dos nutrientes estudados, obtidas no item 5.2 , estão resumidas na Tabela 31 .

TABELA 31 - Extração e exportação de nutrientes pelas cultivares, em $\mathrm{kg} / \mathrm{ha}$

\begin{tabular}{|c|c|c|c|c|c|c|c|}
\hline \multirow{2}{*}{ Cultivar } & \multirow[b]{2}{*}{1} & \multicolumn{6}{|c|}{ Nutrientes } \\
\hline & & $\mathrm{N}$ & $\mathbf{P}$ & $\mathbf{R}$ & $\mathrm{Ca}$ & Mg & $S$ \\
\hline $\begin{array}{l}\text { Branca de } \\
\text { Sänta }\end{array}$ & $\begin{array}{l}\text { Planta } \\
\text { Inteira }\end{array}$ & 123,1 & 13,6 & 77,1 & 64,3 & 18,1 & 9,2 \\
\hline Catarina & Raízes & 39,3 & 4,5 & 25,8 & 12,0 & 6,3 & 1,4 \\
\hline Mantiquei & $\begin{array}{l}\text { Planta } \\
\text { Inteira }\end{array}$ & 103,5 & 8,3 & 80,0 & 59,6 & 18,9 & 7,4 \\
\hline & Raízes & 38,8 & 3,3 & 39,1 & 12,2 & 7,0 & 1,9 \\
\hline
\end{tabular}

(*) Calculado para uma população de 16.666 plantas.

A extração de nutrientes necessária para produzir 1 (uma) tonelada de raízes e a extração de nutrientes somente pelas raízes ( 1 tonelada), ou seja, as quantidades exportadas, são as apresentadas na Tabela 32 . Esta transformação foi efetuada com os dados da Tabela 31 e considerando as produções de 16,2 e 21,5 t/ha de raizes, respectivamente, para as culti- 
vares Branca de Santa Catarina e Mantiqueira e teve por objeti vo facilitar a comparação com os dados da literatura.

Assim, os dados obtidos podem ser comparados com os da Tabela 3 . Verifica-se que o nitrogênio, cálcio e magnésio estão contidos nos intervalos e próximos às médias. 0 fös foro e potássio, estiveram abaixo da média. Para o enxofre não se encontrou citação na literatura.

Embora exista variação na exportação de nutrientes para as cultivares, as maiores diferenças referem-se à extração (Tabela 32). Isto se deve, em parte, a partição diferencial da matéria seca total (raízes + hastes + folhas) entre as cultivares (item 5.1) e a maior concentração de nutrientes na par te aérea (folhas e hastes) em relação às raízes. 
TABELA 32 - Extração e exportação de nutrientes, em quilos, para l (uma) tonelada de raízes

\begin{tabular}{|c|c|c|c|c|c|c|c|}
\hline & \multirow{2}{*}{ Cultivar } & \multicolumn{6}{|c|}{ Elementos } \\
\hline & & 1 & $\mathbf{P}$ & $\mathrm{K}$ & Câ: & $\mathrm{Mg}$ & $S$ \\
\hline & $\begin{array}{c}\text { Branca de } \\
\text { Santa } \\
\text { Catarina }\end{array}$ & 7,60 & 0,84 & 4,76 & 3,97 & 1,12 & 0,57 \\
\hline \multirow[t]{2}{*}{ Extração } & $\begin{array}{l}\text { Mantiquei- } \\
\text { ra }\end{array}$ & 4,81 & 0,39 & 3,72 & 2,77 & 0,88 & 0,34 \\
\hline & Média & 6,21 & 0,62 & 4,24 & 3,37 & 1,00 & 0,46 \\
\hline \multirow{3}{*}{ Exportação } & $\begin{array}{l}\text { Branca de } \\
\text { Santa } \\
\text { Catarina }\end{array}$ & 2,43 & 0,28 & 1,59 & 0,74 & 0,39 & 0,09 \\
\hline & $\begin{array}{l}\text { Mantiquei- } \\
\text { ra }\end{array}$ & 1,80 & 0,15 & 1,82 & 0,57 & 0,33 & 0,09 \\
\hline & Média & 2,12 & 0,22 & 1,71 & 0,66 & 0,36 & 0,09 \\
\hline
\end{tabular}


82 .

6 - CONCLUSŌES

Pelos dados obtidos, conclui-se que:

\section{Crescimento:}

- As cultivares diferiram na produção de matéria seca de raízes, embora não apresentassem diferença significativa em ré 1 ação a matéria seca total.

- Para uma população de 16.666 plantas/ha, a produção mäxima de matéria seca nde raízes foi de 8.465 e $6.543 \mathrm{~kg} / \mathrm{ha}$ e a produção máxima de matéria seca total atingiu 13.726 e $12.968 \mathrm{~kg} / \mathrm{ha}$, respectivamente, para as cultivares Mantique ra e Branca de Santa Catarina. 
- No período de maior acumulação de matéria seca total (120 180 dias), as cultivares Mantiqueira e Branca de Santa Cata rina, acumularam em média 114,2 e $95,7 \mathrm{~kg} / \mathrm{ha} / \mathrm{dia}$, respectivamente.

\section{Absorção dos Macronutrientes:}

- As cultivares diferiram em relação às épocas de absorção pạ ra fósforo e cálcio, sendo que, só para o fósforo as quantí dades extraídas foram diferentes.

- 0 máximo de absorção para os nutrientes ocorreu nas seguin tes épocas, em dias: N (126-127), P (141), K (136), Ca (141), Mg $(142-148)$ e S $(138-144)$.

Produção de Raízes:

- As cultivares diferiram na produção de raízes frescas. As quantidades produzidas foram 21,5 e 16,2 tha, respectioa mente, para as cultivares Mantiqueira e Branca de Santa Catarina.

- A cultivar Mantiqueira foi mais precoce na produção de raízes.

Extração e Exportação de Nutrientes:

- As cultivares extraỉram quantidades diferentes de fósforo e exportaram quantidades diferentes de potássio e enxofre. 
84.

- A extração dos elementos, em ordem decrescente, foi em $\mathrm{kg} / \mathrm{ha}: \mathrm{N}(104-123), \mathrm{K}(77-80), \mathrm{Ca}(60-64), \mathrm{Mg}(18-$ 19), P $(8-14)$ e S $(7-9)$.

- A exportação dos elementos obedeceu a seguinte ordem decrescente, em kg/ha: N (39), $\mathrm{K}(26-39), \mathrm{Ca}(12), \mathrm{Mg}$ $(6-7), P(3-5)$ e $S(1-2)$. 
85.

7 - SUMMARY

This paper déals with the results of a field experi ment conducted in order to study dry matter production and macronutrients accumulation by two cassava cultivars, 'Branca de Santa Catarina' and 'IAC Mantiqueira! .

Plants received a uniform dressing of $N, \mathrm{P}_{2}{ }^{0}{ }_{5}$ and $\mathrm{K}_{2} \mathrm{O}$ of 40,80 and $60 \mathrm{Kg} / \mathrm{ha}$, respectively as ammonium sulfate, simple superphosphate, and muriate of potassium: $N$ was top dressed 60 days after emergence.

Two irrigations were provided in the beginning of the growth cycle due occurrence of a drought period. 
Plants were sampled and analysed for growth parameters and macronutrient composition in six occasions with 60 days of interval.

The main conclusions and relevant data were the fol lowing:

1 - There was statistical difference in root production of the two cultivars; maximum dry matter accumulation took place in the period of $120-180$ days after emergence.

2 - Peaks of absorption of macronutrients coincided with maximum rates of dry mattex production.

3 - Extraction of macronutrients was the same in the two cul tivars, P excepted; export was different only in the ca se of $K$ and $S$. 
ALbUQUERQUE, M., 1969. A mandioca na Amazônia. Belém, Supe rintendência do Desenvolvimento da Amazônia. $277 \mathrm{p}$.

BARRIOS, E. A. e R. BRESSANI, 1967. Composición química de la raíz y de la hoja de algunas variedades de yuca. Turrialba, $17(3): 314-320$ 。

BAtaglia, 0. C. e J. R. GAllo, 1972. Determinação de cálcio e de magnésio em plantas por fotometria de chama de absor ção. Bragantia, Campinas, 31: 59-74.

BONNEFOY, J. V., 1933. Calcul des éléments fertilizants enlevés au sol par une récolte de manioc. Bulletin Economi que, Madagascar, (83): 75-77. 
CATANI, R. A. ; J.R. GALLO e H. GARGANTINI, 1954. Extração de elementos nutritivos do solo por diversas culturas. Campinas, Instituto Agronômico. (Cartaz).

CONCON, J. M. e D. SOLTESS, 1973. Rapid micro Kjeldahl digestion of cereal grains and others biological materials. Analytical Biochemistry, New York, 53(1): 35-41.

Cours, G., 1951. Le manioc à Madagascar. Mémoires de l'Ins. titut Scientifique de Madagascar. Sér. B:. Biologie Végétale, Tananarive, 3(2): 203-416.

COURS, G., 1953. Le diagnostic foliaire et les carences. Recherche Agronomique de Madagascar, Compte Rendu, Tana narive, (2) : 78-84.

DE GEUS, J.G., 1967. Root crops: cassava. In: Fertilizer guide for tropical and subtropical farming. Zurich, Centre D'Etude de 1'Azote, p. 181-185.

DUFOURNET, R. e P. GOARIN, 1957. Note sur la culture du manioc à Madagascar. Riz et riziculture et cultures vivrié res tropicales, Nogent-sur-Marne, $\underline{3}(1): 15-38$.

DULONG, R., 1971. Le manioc a Madagascar. Arronomie tropicale, Nogent-sur-Marne, 26(8): 791-829.

FAO, 1975. Production Yearbook. Rome, vo1. 29.

FOX, R. H. ; H. TALLEYRAND e T. W. SCOTT, 1975. Effect of nitrogen fertilization on yields and nitrogen content of cassava, Llanera cultivar. Journal of Agriculture of the University of Puerto Rico, Rio Piedras, 59(2): 115-124. 
FUNDAÇÃo IBGE, 1975. Anuário Estatistico do Brasil, Rio de Janeiro, Vol. 36, p. 167 .

GEHRKE, C. W. ; L. L. WALL e J. S. ABSHERR, 1973. Automated nitrogen method for fields. Journal of the Association of official Agricultural Chemists, Washington, 56(5): 1096-1105.

GOMES, F. P., 1973. Curso de Estatistica Experimental. 7 ? $^{a}$ ed., São Paulo, Editora Nobel, 430 p.

HONGSAPAN, S., 1962. Does planting of cassava really impoverish the soil? Kasikorn, 35(5): 403-407. Apud HOWE LER, R. H., 1978 .

HOWELER, R. H., 1975. Requerimento de elementos secandários e elementos menores da mandioca. In: Curso Espe cial de Aperfeiçoamento para Pesquisadores de Mandioca, Cali, Colómbia, CIAT, $14 \mathrm{p}$.

HOWELER, R. H., 1978. Nitrición mineral y fertilización de la yuca. In: Curso de producción de yuca. Cali, Colôm bia, CIAT, vol. 1, p. 274-321.

HUNT, L. A. ; D. W. WHOLEY e 3. H. COCK, 1977. Growth physiology of cassava (Manihot esculenta, Crantz). Field Crop Abstracts, $30(2):$ 77-91.

INSTITUTO AGRONômico, Campinas. Seção de Raízes e Tubércu1os, $1937 / 1975$. Re1atörios anuais.

KANAPATHY, K. e G. A. KEAT, 1970. Gowing maize, sorghum and tapioca on peat soil. In: Proceedings of the Confe rence on Crop Diversification in Malaysian, Ruala Lum pur, p. 25-35. 
KANAPATHY, K., 1974. Fertilizer experiments on shallow peat under continuous cropping with tapioca. The Malaysian agricultural Journal, Kuala Lumpur, 49(4): 403-412.

KROCHMAL, A. e G. SAMUELS, 1968. Deficiency symptoms in nutrient pot experiments with cassava. Ceiba, Tegucigal pa, 14: 1-9.

LOTT, W. L.; J. P. NERY; J. R. GALLO e J. C. MEDCALF, 1956 . A tēcnica de anālise foliar aplicada ao ca ceeiro. Campi nas, Instituto Agronômico, 29 p. (Boletim, 79).

LOTT, W. L. et alii, 1961. Levantamento de cafezais em são Paulo e Paraná pela análise foliar. São Paulo, IBEC Research Institute. 69 p. (Boletim, 26).

MALAVOLTA, E. et alii, 1954. Estudos sobre alimentação mine ral da mandioca. Anais da E. S. A. "Luiz de Queiroz", Piracicaba, 10: 217-222.

MEJIA, F. R., 1946. El cultivo de la yuca, y su Explotación industrial. Agricultura tropical, Bogotá, $2(3): 13-21$. Apud HOWELER, R. H., 1978 .

MENDES, C. T., 1940. Contribuição para o estudo da mandio ca. São Paulo, Secretaria da Agricultura, Indústria e Comërcio. $99 \mathrm{p}$.

MUTHUSWAMY, P. et alii, 1975. Composition and nutritive value of certain cultivars of cassava tubers (Manihot esculenta, (rantz). Madras agricultural Journa1, 62 (2): 68-70. 
NESTEL, B., 1973. Current Utilization and Future Potencial for cassava. In: Proceedings of Chronic Cassava Toxici ty, London, p. 11-26.

NGONGI, A. G. N., 1976. Influence of some mineral nutrients on growth, composition and yield of cassava (Maninot esculenta, Crantz). Ithaca, Cornell Un. (Ph.D. Thesis). Apud HOWELER, R. H., 1978 .

NIJHOLT, J.A., 1935. Opname van voendingsstoffen uit den bodem bij cassave. Algemeen Proefstation joor den Landbouw. Buitenzorg, Korte Mededeelingen n! 15. Apud HOWELER, R. H., 1978 .

NORMANHA, E. S., 1966. As folhas de mandioca servem como a limento. OEstado de São Paulo, São Paulo, 9 mar. 1966. Suplemento agrícola 567: 4 .

OELSLIGLE, D. D., 1975. Accumulation of dry natter, nitrogen, phosphorus, and potassium in cassava. Turrialba, 25(1): $85-87$.

PEREIRA, A. S. ; J . O LORENZI e E. ABRAMIDES, 1977 . Competição de variedades de mandioca. Campinas, Instituto Agronômico. 7 p. (Circular, 68).

PERKIN-ELMER CORPORATION, 1971. Analytical Methods for Atomic Absortion Spectrophotometry. Norwalk, Connecticut.

ROCHE, P. ; J. VELLY e B. JOLIET, 1957. Essai de détermination des seuils de carence en potasse dans le sol et dans les plants. Revue de la Potase, Section 6 , Berne, $p$. $1-5$. 
SARRUGE, J. R. e H. P. HAAG, 1974. Anälise qiimica em plantas. Piracicaba, ESALQ-USP, $52 \mathrm{p}$.

SETZER, J., 1966. Atlas Climático e Ecolögics do Estado de São Paulo. São Paulo, Instituto Geológics e Geogrä́ico, p. 35-38.

SOLORZANO, N. e E. BORNEMISZA, 1976. Estudios del cultivo de yuca en Costa Rica. II. Composición química y producción de tres cultivares. Turrialba, 26(3): 261-264.

TEIXEIRA, J. P. F. et alłi, 1976. Determinação automatizada de enxofre em plantas, pelo sistema auto-analisador II Technicon. Bragantia, Campinas, 35(1): LXXVIIIXXXI.

VELLY, J., 1969. Contribution à la determinazion de la fumure d'entretien; les exportations en elenents mineraux de principales cultures. Bulletin de Madagascar, (282): 872-890. Apud HOWELER, R. H., 1978.

VIEGAS, A. P., 1976. Estudos sobre a mandioca. São Paulo. IAC, / BRASCAN NORDESTE, $214 \mathrm{p}$. 